UNIVERSIDADE DE SÃO PAULO

FACULDADE DE FILOSOFIA, CIÊNCIAS E LETRAS DE RIBEIRÃO PRETO DEPARTAMENTO DE PSICOLOGIA

PROGRAMA DE PÓS-GRADUAÇÃo EM PSICOLOGIA

\title{
Decisão de carreira na transição da universidade para o mercado de trabalho: validação de instrumento de medida.
}

\author{
Juliana Maria Cava
}

Dissertação apresentada ao Programa de PósGraduação em Psicologia da Faculdade de Filosofia, Ciências e Letras de Ribeirão Preto da Universidade de São Paulo como parte dos requisitos para obtenção do grau de Mestre em Ciências, Área: Psicologia.

Ribeirão Preto 



\title{
Decisão de carreira na transição da universidade para o mercado de trabalho: validação de instrumento de medida.
}

Orientadora: Profa. Dra. Lucy Leal Mello Silva

\begin{abstract}
Dissertação apresentada ao Programa de PósGraduação em Psicologia da Faculdade de Filosofia, Ciências e Letras de Ribeirão Preto da Universidade de São Paulo como parte dos requisitos para obtenção do grau de Mestre em Ciências, Área: Psicologia.
\end{abstract}


AUTORIZO A REPRODUÇÃO TOTAL OU PARCIAL DESTE TRABALHO, POR QUALQUER MEIO CONVENCIONAL OU ELETRÔNICO, PARA FINS DE ESTUDO E PESQUISA, DESDE QUE CITADA A FONTE.

FICHA CATALOGRÁFICA

Cava, Juliana Maria

Decisão de carreira na transição da universidade para o mercado de trabalho: validação de instrumento de medida. Ribeirão Preto, 2012.

128 p. : il. ; $30 \mathrm{~cm}$

Dissertação de Mestrado, apresentada à Faculdade de Filosofia, Ciências e Letras de Ribeirão Preto/USP. Área de concentração: Psicologia.

Orientador: Melo-Silva, Lucy Leal.

1. Orientação Profissional. 2. Avaliação Psicológica. 3. CDDQ 4. Universitários. 5. Validade. 


\section{FOLHA DE APROVAÇÃO}

Nome: Cava, Juliana Maria

Título: Decisão de carreira na transição da universidade para o mercado de trabalho: validação de instrumento de medida.

Dissertação apresentada à Faculdade de Filosofia, Ciências e Letras de Ribeirão Preto da Universidade de São Paulo como parte dos requisitos para obtenção do grau de Mestre em Ciências, Área: Psicologia

Aprovado em 12012

\section{Banca Examinadora}

$\operatorname{Prof}^{\mathrm{a}} \mathrm{Dr}^{\mathrm{a}}$ LUCY LEAL MELO-SILVA

Instituição: Faculdade de Filosofia Ciência e Letras de Ribeirão Preto - USP

Assinatura:

Prof $^{\mathrm{a}} \mathrm{Dr}^{\mathrm{a}}$ THAIIS ZERBINI

Instituição: Faculdade de Filosofia Ciência e Letras de Ribeirão Preto - USP

Assinatura:

Prof. Dr. MARCO ANTONIO PEREIRA TEIXEIRA

Instituição: Universidade Federal do Rio Grande do Sul

Assinatura: 



\section{Dedicatória}

À minha filha Maria Luiza, que ainda não nasceu, mas que já desperta o mais profundo sentimento: Amor.

Aos meus pais, Cássio e Nilza, fundamentais.

À minha irmã, Daniele, amiga.

Ao meu amor, André pelo companheirismo e dedicação. 



\section{AGRADECIMENTOS}

À minha filha Maria Luiza que me proporcionará a mais linda experiência da vida: ser mãe.

Aos meus pais, Cassio e Nilza, pais interamente dedicados, que me criaram como pessoa e profissional e que me proporcionaram tudo o que precisei para chegar até mais esta conquista, minha gratidão.

À minha irmã, Daniele, inspiradora dos meus estudos e sempre amiga.

Ao André, companheiro de todas as minhas conquistas, fundamental pra execução deste trabalho.

À Profa. Lucy de Melo-Silva, minha orientadora e exemplo de pessoa e profissional, desde a graduação. Pessoa que admiro por sua atuação em todas as esferas da vida, mãe, professora, orientadora, pesquisadora, enfim mulher.

À Profa. Dra. Thaís Zerbini e ao Prof. Dr. Marco Teixeira, pela disponibilidade e colaboração essencial para o enriquecimento e desenvolvimento metodológico deste trabalho.

Ao corpo docente da Faculdade de Filosofia Ciências e Letras de Ribeirão Preto, por terem me proporcionado a oportunidade de me tornar profissional, impagável a dedicação dos professores na formação de seus alunos desde a graduação.

À Profa. Marina Cardoso, por sua contribuição no desenvolvimento deste trabalho e sua amizade.

À Andressa Kutschenko, estatística, pela valiosa colaboração no tratamento e análise dos dados.

Ao grupo de pesquisa da Profa Lucy: Maria Luiza, Izildinha, Mara, Neirielen, Fernanda, Wadson, por suas contribuições e companheirismo. 
Ao Prof. Dr. Sergio S. Fukusima por me acolher em minha Iniciação Científica, incentivando e despertando meu interesse para a pesquisa.

Às minhas amigas de infância - Daniele, Alessandra, Maria, Ana Paula, Fernanda, Raphaela que mesmo distantes, devido as suas conquistas, sempre incentivadoras de meu percurso.

A todos os docentes e funcionários da Pós-Graduação do Programa de Psicologia da Faculdade de Ciências e Letras de Ribeirão Preto, pelo constante acompanhamento e ajuda na realização deste trabalho.

A todos os amigos, familiares, professores que me ajudaram e ensinaram de alguma forma. Obrigada! 


\section{RESUMO}

Cava, J. M. (2012). Decisão de carreira na transição da universidade para o mercado de trabalho: validação de instrumento de medida. 128 f. Dissertação de Mestrado, Departamento de Psicologia, Faculdade de Filosofia, Ciências e Letras de Ribeirão Preto, Universidade de São Paulo.

As decisões relacionadas com a carreira assumem um papel preponderante na vida de um indivíduo, sendo assim um dos temas mais trabalhados desde a fundação da Psicologia Vocacional no contexto da educação e do trabalho. No sistema educacional brasileiro, em todos os níveis, rara é a oferta de suporte aos estudantes no que se refere à educação, desenvolvimento e decisão de carreira. São poucas as iniciativas desenvolvidas nas Instituições de Ensino Superior que objetivam intervir em questões e problemas relacionados ao desenvolvimento da carreira de universitários. Visando contribuir para a ampliação do conhecimento sobre questões da decisão de carreira de estudantes universitários no Brasil e oferecer instrumento apropriado para avaliação e intervenção nesse domínio, este estudo teve como principal objetivo, analisar as qualidades psicométricas da adaptação e validação da versão brasileira do Questionário de Dificuldades de Tomada de Decisão de Carreira do CDDQ de autoria de Gati e colaboradores. Para atingir tais objetivos os dados foram coletados em dois momentos diferentes com 511 universitários, de instituições públicas e particulares, organizados em duas amostras sendo a primeira $(n=11)$ para a validação semântica, a segunda $(\mathrm{n}=500)$ para a validação estatística (fatorial). Para a validação semântica foram feitos: tradução, retradução, análise dos itens e ensaio experimental. Os resultados dessa etapa indicaram a necessidade de modificações em apenas uma das questões (item 30). Para a validação estatística foram realizadas análises fatoriais e testes de confiabilidade no sentido de verificar a estrutura do instrumento de acordo com o modelo de dificuldades de tomada de decisão vocacional de Gati, Krausz e Osipow. Em sua versão original o instrumento possui 34 itens divididos em três fatores. O fator 1 (12 itens) relacionase com dificuldades relativas à Falta de Informação, o fator 2 (12 itens) engloba dificuldades relacionadas com Informação Inconsistente e o fator 3 (10 itens) inclui dificuldades relativas à Prontidão. Os resultados confirmaram a estrutura fatorial e indicaram boa confiabilidade geral do instrumento CDDQ (alfa de Cronbach de 0,92). A análise fatorial dos eixos principais (PAF) e de consistência interna das dimensões do CDDQ34 indicou uma solução de três fatores (Prontidão $\alpha=0,58$; Falta de Informação $\alpha=0,92$; Informações inconsistentes $\alpha=$ 0,86). O fator 1 , que se relaciona com falta de informação, passou a ser composto por 18 itens, o fator 2 que se relaciona com informação inconsistente por 9 itens, e o fator 3 Prontidão com 4 itens. A escala Prontidão mostrou-se com menor confiabilidade confirmando os achados da literatura internacional, e apresentando apenas 4 dos 10 itens propostos no original, desta forma deve ser melhor analisada para sua utilização no contexto brasileiro. Por fim, o CDDQ mostrou-se como um instrumento promissor na utilização com universitários, porém necessita de maiores adaptações de seus itens, principalmente na escala Prontidão.

Palavras-Chave: Desenvolvimento de Carreira, Orientação Profissional, Avaliação Psicológica, CDDQ, Universitários, Validade de Instrumento. 



\begin{abstract}
Cava, J. M. (2012). Career decision making in the university-to-work transition: validation of measurement instrument. $128 \mathrm{f}$. Thesis (Master's Degree) - University of São Paulo at Ribeirão Preto, Faculty of Philosophy, Sciences and Letters from Ribeirão Preto, University of São Paulo.

Career decisions play a key role in the life of an individual and it is one of the most studied and worked construct in Vocational Psychology. However, the brazilian educational system at all levels, rarely supports students in their career education, development and decision. There is only a few initiatives in the higher education institutions that aim to intervene in issues and problems relating to the career development of students. Aiming to increase the knowledge about the career decision of brazilians college students and provide a tool for this purpose, this study had as objective, analyze the psychometric properties of the adaptation and validation of the Brazilian version of Career Decision Making Difficulties Questionnaire (CDDQ) authored by Gati et al. To achieve this objective the data were collected at two different moments, attended by 511 academics from public and private institutions, divided into two samples being the first one to semantic validation and the second one for the statistical validation. For semantic validation were made the translation, retranslation, item analysis and experimental testing. The results indicated that the instrument needs modifications in one of the items (item 30). For statistical validation, factor analyzes and reliability tests were performed in order to verify the structure of the instrument according to the career decision-making difficulties proposed by Gati, Krausz, and Osipow (1996). The original instrument has 34 items divided into three factors. The factor 1 (12 items) refers to difficulties related to lack of information, the factor 2 (12 items) includes difficulties associated with Inconsistent Information and factor 3 (10 items) includes difficulties related to readiness. The results confirmed partially the factor structure and indicated good reliability of the instrument CDDQ $(\alpha=0.92)$. The principal axis factor analysis (PAF) and internal consistency of the dimensions of CDDQ34 indicate a three-factor solution (Readiness $\alpha=$ 0.58 , Lack of Information $\alpha=0.92$, Inconsistent Information $\alpha=0.86$ ). The factor that relates to a lack of information is now composed of 18 items, the factor inconsistent information by 9 items, and the factor Readiness by 4 items. The analyses showed that the factor readiness has lower reliability confirming the findings of international literature, and remaining only four items of the 10 proposed in the original, so should be better analyzed for their use. Finally, the CDDQ proved to be a promising tool to assess career decision making difficults of college students, but needs further adaptations of their items, especially on the scale Readiness.
\end{abstract}

Keywords: Career Development, Career Counseling, Psychological Assessment, CDDQ, College Students, Validity of the Instrument. 



\section{LISTA DE QUADROS E FIGURAS}

Quadro 1 - Quadro da Taxionomia de Dificuldades de Tomada de Decisão de Carreira de Gati e cols (1996).

Quadro 2 - Quadro das categorias principais organizadas em escalas e os números de itens do CDDQ

Figura 1 - Taxonomia das Dificuldades de Tomada de Decisão na Carreira (Gati, Osispow, 1996)

Figura 2 - Distribuição dos valores próprios (scree plot) do Questionário de Dificuldade de Tomada de Decisão 86 



\section{LISTA DE TABELAS}

Tabela 1 - Estudos de Confiabilidade do CDDQ

Tabela 2 - Estudos de Teste-Reteste do CDDQ

Tabela 3 - Distribuição da amostra $(n=500)$ em função do curso de graduação 64

Tabela 4 - Distribuição da amostra $(\mathrm{n}=500)$ por área de curso 65

Tabela 5 - Distribuição da amostra $(\mathrm{n}=500)$ por faculdade 65

Tabela 6 - Distribuição da amostra $(n=500)$ por classe social segundo os critérios da ABEP. 65

Tabela 7 - Distribuição da amostra $(n=500)$ por escolaridade do chefe de família...... 66

Tabela 8 - Descrição da média, desvio-padrão e percentual de concentrações de respostas do CDDQ.

Tabela 9 - Descrição da Média e desvio padrão das subescalas e escalas principais do CDDQ

Tabela 10 - Variância total distribuída em 3 fatores 85

Tabela 11 - Carga fatorial dos itens do CDDQ distribuídos em 3 fatore 86

Tabela 12 - Índices de validade fatorial confirmatória 94

Tabela 13 - Índices do alfa de Cronbach para o CDDQ 95 



\section{LISTA DE ANEXOS E APÊNDICES}

ANEXO A - Questionário ABEP

ANEXO B - Termo de Consentimento Livre e Esclarecido

ANEXO C - Autorização do Comitê de Ètica em Pesquisa

ANEXO D - Autorização para utilização do CDDQ e sua condições

APÊNDICE A - Descrição das escalas do CDDQ por sexo e resultados das comparações com os fatores

APÊNDICE B - Descrição das escalas do CDDQ por estado civil e resultados das comparações com os fatores

APÊNDICE C - Descrição das escalas do CDDQ por faculdade e resultados comparações com os fatores

APÊNDICE D - Descrição das escalas do CDDQ por inserção e resultados das comparações com os fatores

APÊNDICE E - Descrição das escalas do CDDQ por nível de confiança e resultados das comparações com os fatores

APÊNDICE F - Descrição das escalas do CDDQ por classe social e resultados das comparações com os fatores

APÊNDICE G - Descrição das escalas do CDDQ por área de curso e resultados das comparações com os fatores 



\section{SUMÁRIO}

1. APRESENTAÇÃO....................................................................................................23

2. INTRODUÇÃO ................................................................................................................... 29

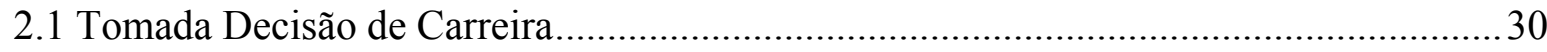

2.2 A tomada de decisão de carreira e o modelo proposto por Itamar Gati e seus colaboradores.

2.3 Estudos de validação do Questionário de Dificuldades de Tomada de Decisão para a Carreira.

2.4 As transições durante o Ensino Superior e o desenvolvimento de carreira. 49

2.5 O universitário brasileiro e a transição. 52

3. OBJETIVO 57

3. 1. Geral. 58

4. MÉTODO. 61

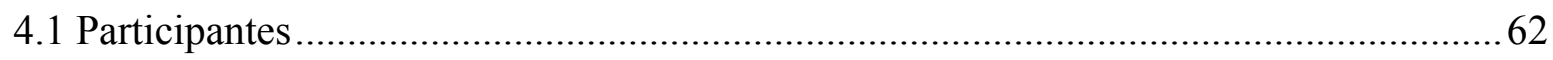

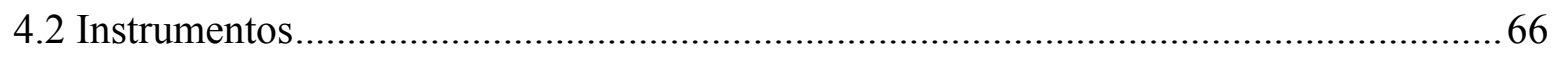

4.2.1 Questionário de Dificuldade de Tomada de Decisão (CDDQ- R) ...........................66

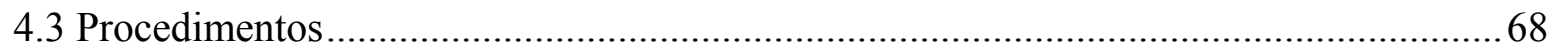

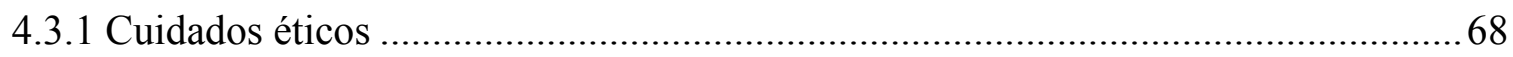

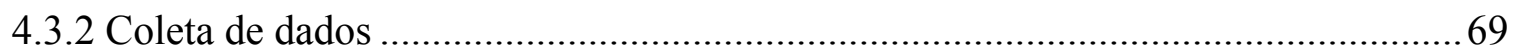

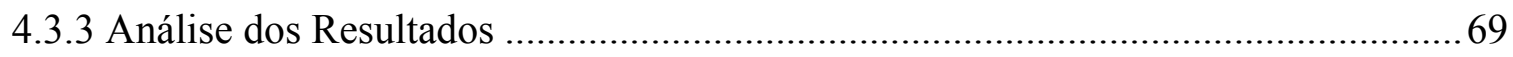

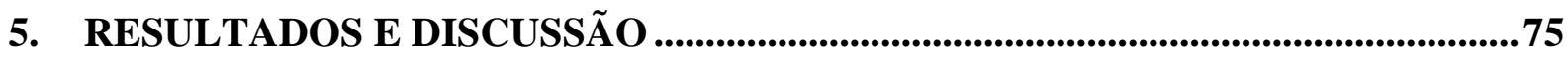

5.1 Validação Semântica e pertinência dos itens do CDDQ............................................... 77

5.2 Análises descritivas das dificuldades de tomada de decisão para a carreira................... 81 


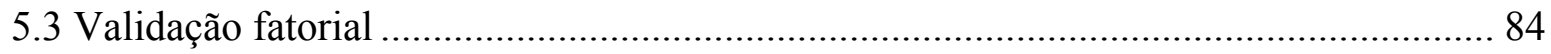

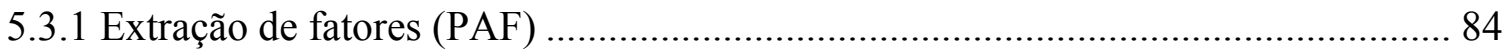

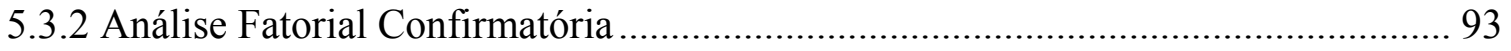

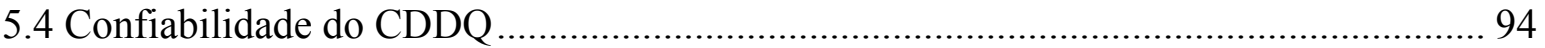

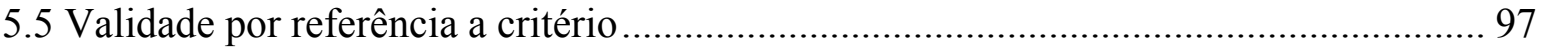

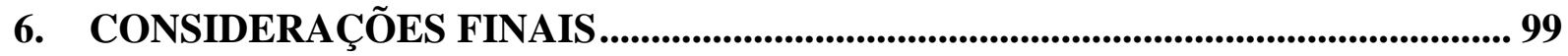

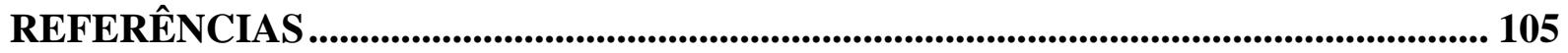

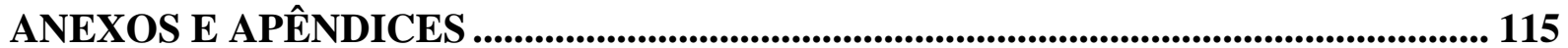


1. APRESENTAÇÃO 

Enquanto alguns indivíduos tomam decisões de carreira facilmente, outros se deparam com dificuldades na tomada de decisão, muitas vezes procurando ajuda de um profissional (GATI; OSIPOW, 1996; KÖNGSTEDT, 2008; SILVA; RAMOS, 2008). As decisões relacionadas com a carreira assumem um papel preponderante na vida de um indivíduo, sendo assim um dos temas mais trabalhados desde a fundação da Psicologia Vocacional (CRITES, 1969).

O sistema educacional brasileiro, em todos os níveis, raramente oferece suporte aos estudantes no que se refere à educação e desenvolvimento de carreira. São poucas as iniciativas desenvolvidas nas Instituições de Ensino Superior (IES) que objetivam intervir em questões e problemas relativos ao desenvolvimento da carreira de universitários. Essa deficiência, observada nos egressos de carreiras universitárias, evidencia, mais ainda, a falta de preparação para transição e o que afeta diretamente os resultados acadêmicos e o ingresso posterior do graduado no mercado de trabalho (JENSCHEKE, 2002).

Pesquisas realizadas nos Estados Unidos, Canadá, Austrália, União Europeia, Grécia e Japão (WENDLANT; ROCHLEN, 2008; BUHL, 2007; WOODS, 2008; MARKS, 2005; CHAVACCI, 2005) apontam que disciplinas voltadas à educação de carreira (JENSCHEKE, 2002) produzem efeitos nas variáveis de maturidade, tomada de decisão, identidade vocacional e autoeficácia.

As ações educacionais direcionadas ao planejamento e desenvolvimento de carreira tem se mostrado como atividades críticas, facilitando, ou não, a transição de milhões de estudantes universitários que estão à procura de futuros empregos, treinamento, educação continuada. O desafio das universidades é criar condições para que a maioria dos estudantes, em especial aqueles insuficientemente envolvidos nas atividades de exploração profissional, transformem-se em participantes ativos no processo de desenvolvimento de carreira (COLLOZZI, 2004).

Ao revisar a literatura da área, alguns aspectos mostraram-se relevantes para o entendimento da complexidade de fatores que estão relacionados ao desenvolvimento de carreira dos estudantes universitários. A indecisão, no campo de estudos mais gerais sobre a tomada de decisão comportamental, mostrou-se de grande relevância, no que se faz necessário entender o motivo pelo qual algumas pessoas têm dificuldades em decidir acerca de seu futuro vocacional, enquanto outras conseguem tomar decisões mais facilmente, e como isto interfere na vida dos universitários e em suas expectativas para a transição da universidade para o mercado de trabalho. 
Bardagi, (2010) ressalta que, apesar de existir alguns pesquisadores interessados em discutir o desenvolvimento de carreira dos estudantes universitários, a maioria dos estudos nacionais concentra-se em amostras de adolescentes ou aborda questões relativas à entrada no mercado de trabalho ou, ainda, a problemática dos profissionais já inseridos na esfera produtiva. Por outro lado, mais estudos precisam ser realizados para que haja a compreensão dos vários fatores que afetam o desenvolvimento de carreira dos universitários.

A problemática do desenvolvimento de carreira em universitários e da transição para o mercado de trabalho constituem-se em fenômenos de meu interesse pessoal, e, para abordálos parto do prisma da Avaliação Psicológica e da Orientação Profissional, duas áreas da Psicologia que me despertaram grande interesse durante a graduação. Ao concluir o curso de Psicologia na Universidade de São Paulo (USP), campus de Ribeirão Preto em dezembro de 2006, fui aprovada em um concurso público, naquele mesmo ano, para exercer a função de Psicóloga Fiscal do Conselho Regional de Psicologia (CRP) de Minas Gerais, ingressando no trabalho imediatamente após a conclusão da graduação. Em um período de 18 meses de serviços prestados ao $\mathrm{CRP} / \mathrm{MG}$, deparei com a grande dificuldade dos psicólogos recémformados de ingressarem no mercado de trabalho, sendo diversas as causas dessa dificuldade. Em reuniões denominadas "Entrega de Carteira", o documento de registro profissional, tive contato com mais de 1.500 recém-formados em Psicologia que em mim depositavam suas angústias e dificuldades em pensar em suas carreiras. Essa experiência como psicóloga fiscal, despertou a vontade de estudar a área de transição da universidade para o mercado de trabalho.

Minha proximidade com testes psicológicos sempre foi muito grande, atualmente trabalho em uma Clínica Médica e Psicológica credenciada ao Departamento de trânsito de Minas Gerais (DETRAN/MG), que realiza avaliação psicológica para condutores de veículos. Além dos serviços prestados como Assistente Técnica em Avaliações Psicológicas para a Prefeitura Municipal de Poços de Caldas, seja no campo do trânsito, na clínica ou em orientação profissional, nos mais variados contextos, utilizo de instrumentos psicológicos para meu exercício como psicóloga. Recentemente, em 2011, fui convidada a ministrar aulas de Orientação Profissional e Técnicas de Avaliação Psicológica na Faculdade Pitágoras de Poços de Caldas, influenciando ainda mais meu campo de estudos nas duas áreas.

De certa maneira, creio que estes contatos e influências acabaram por aumentar meu interesse em instrumentos de avaliação psicológica, levando-me a tentar realizar um estudo focado em características psicométricas de instrumento de avaliação psicológica, ou seja, relativo à construção e à validação das técnicas, buscando evidências empíricas para a 
utilização de um instrumento que auxiliassem no processo de Orientação de Carreira para universitários.

Nesse sentido, visando contribuir para a ampliação deste campo de estudo no Brasil, o presente trabalho teve como objetivo realizar estudos sobre a validade e confiabilidade de instrumento de medida relacionado às dificuldades de Tomada de Decisão para a Carreira (CDDQ) com universitários em final de curso, de três universidades brasileiras.

Com expectativas de resultados, espera-se que este estudo contribua para o desenvolvimento teórico e prático dos profissionais e pesquisadores interessados em aprofundar seus conhecimentos sobre o desenvolvimento de carreira dos estudantes universitários do nosso país, de modo a fornecer instrumento que poderá pautar a prática e a pesquisa nesse domínio do conhecimento.

Sendo assim, o presente estudo foi estruturado apresentando, inicialmente, uma Introdução que: contextualiza a transição e o universitário brasileiro, as teorias referentes à tomada de decisão na carreira, os estudos internacionais do CDDQ e suas qualidades psicométricas, e uma breve descrição de pesquisas internacionais que se utilizam do CDDQ nos diferentes contextos da Orientação de carreira. Em seguida, é explicitado o Objetivo do presente estudo. Os Métodos adotados para se alcançar esses objetivos são descritos na sequência

Posteriormente, são apresentados os Resultados e a Discussão relacionando-os com os objetivos apresentados, integrando-os com a literatura, comparando as qualidades psicométricas encontradas. Por fim, as Considerações Finais encerram o trabalho, retomando os principais resultados e discorrendo acerca das possibilidades e limitações deste instrumento e estudo, apresentando também sugestões de caminhos para novas investigações com o CDDQ, no contexto brasileiro. 
2. INTRODUÇÃO 



\subsection{Tomada Decisão de Carreira}

A tomada de decisão têm se mostrado como um aspecto central de estudo na Psicologia de Carreira. A partir dos postulados dos modelos desenvolvimentistas, a escolha profissional deixa de ser entendida como um momento separado na vida de uma pessoa, passando a ser encarada como um processo, o qual se desenrola durante todo o desenvolvimento vocacional do indivíduo (TIEDEMAN, 1961).

Os modelos desenvolvimentistas propõem que existem fases propícias à ocorrência de transições vocacionais, que tem em si inerente, a necessidade de realizar escolhas (LASSANCE, 2007). No sistema Educacional Brasileiro, a situação de transição na carreira se apresenta aos indivíduos, em grande parte, no final do Ensino Médio e mais adiante no encerramento do Nível Superior, aos que alcançam esta possibilidade de estudos, salvo estes que optam pela qualificação técnica, e neste momento suscitam aos jovens um problema de carreira, inerente à transição universidade/profissão, que implica ao aluno uma escolha com maior importância em relação ao seu futuro profissional. Desta forma, a decisão vocacional é entendida como um processo de desenvolvimento e de construção da identidade composto, não por uma, mas pelo conjunto de decisões que o indivíduo vai tomando, à medida que se desenvolve (TIEDEMAN, 1961).

Em seus primórdios, a intervenção vocacional era concebida como um processo de ajustamento entre as características individuais da pessoa e o leque de oportunidades educacionais e profissionais à sua disposição, num dado momento. Parsons (1909), na sua obra Choosing a Vocation é apontado como um marco de referência no âmbito da Psicologia Vocacional, sintetizando o processo de decisão vocacional (RIBEIRO; UVALDO, 2007). Parsons refere que a escolha vocacional baseia-se em três fatores: (1) "a análise da pessoa", isto é, a compreensão que o indivíduo faz de si e das suas capacidades, aptidões, interesses, ambições, recursos e limitações; (2) "a análise do emprego", ou o conhecimento que o sujeito tem do meio; e (3) "a comparação conjunta e de cooperação desses dois conjuntos de análise", ou seja, o raciocínio acerca das relações entre os dois grupos de fatores anteriores.

Seguindo o modelo parsoniano desenvolveram-se duas abordagens à orientação do comportamento vocacional de decisão profissional: (1) as que privilegiam a primeira etapa do modelo anterior ("man analysis"), seguidas principalmente por psicólogos, que a aperfeiçoaram por meio da criação de testes psicológicos e com o aparecimento das teorias fatoriais e, (2) as que se focam na segunda fase do modelo de Parsons (1909), “Job analysis”, que geralmente é seguida por docentes ou especialistas do mercado de emprego. Da análise de 
emprego, resultou a abordagem Traço-Fator, que durante décadas da primeira metade do século XX consistiu na concepção dominante da Psicologia Vocacional. Nessa abordagem a autonomia do indivíduo para tomar uma decisão profissional é limitada, sendo o psicólogo, o responsável pela designação da via mais adequada ao sujeito. Por sua vez, a decisão vocacional é entendida como um processo isolado, dando-se mais importância ao conteúdo da decisão, em detrimento do processo de tomada de decisão. (RIBEIRO; UVALDO, 2007).

Ao passo que os modelos desenvolvimentistas vão ganhando destaque na Psicologia Vocacional, as escolhas vocacionais deixam de ser percebidas como repentinas e sem antecedentes, não se circunscrevendo a momentos pontuais de decisão. As decisões vocacionais passam então a ser reconhecidas como processos inseridos na carreira do indivíduo, que o acompanham em todos os momentos da sua vida (SAVICKAS, 2007).

Com o aparecimento do conceito de decisão de carreira, pode-se verificar que o processo de tomada de decisão vocacional organiza-se em torno de três abordagens distintas: (1) a que coloca a decisão vocacional num processo evolutivo que ocorre ao longo de vários estágios do desenvolvimento do indivíduo (SUPER; SAVICKAS, 1996); (2) a que observa o modo como as pessoas fazem escolhas, partindo de vários quadros teóricos (GATI, 1996); (3) a que se centra nas variáveis individuais que distinguem os decisores (PHILIPS, 1997).

Desta forma, podemos aferir que o conceito de decisão de carreira parece se centrar em três grandes bases: (1) a decisão aparece em períodos de transição que podem ser problemáticos; (2) a capacidade de o sujeito agir; (3) considerar as realidades e estimar probabilidades de um bom ajustamento.

Para que a decisão ocorra é necessário um decisor, este pressuposto por Jepsen e Dilley (1974). Ao decisor será apresentadas duas ou mais alternativas, e cabe a este, analisar em termos de possibilidades de ocorrência no futuro e importância para si próprio. A decisão vocacional carrega consigo a escolha de um determinado objetivo vocacional, que pressupõe ao indivíduo considerar as várias alternativas possíveis, tendo em conta a possibilidade de sucesso de cada uma delas. Brêda (2001) apresenta a decisão de carreira como um processo que parte de um problema de transição, e este conduz a exploração, valoração e seleção de várias alternativas, através de um processo sistemático, tendo em vista o compromisso com uma alternativa e sua implementação de acordo com o interesse do indivíduo.

Os modelos de tomada de decisão, segundo Jepsen e Dilley (1974) podem ser classificados em três tipos: os modelos descritivos, os prescritivos e os normativos este último propostos por Gati e cols (2008). 
Os modelos descritivos são assim chamados, pois procuram identificar e explicar o processo de tomada de decisão, tal como ele ocorre. Este modelo estuda o fenômeno por meio do qual as pessoas escolhem. Este modelo de decisão consiste na descrição de um processo psicológico no caminho do qual se organiza a informação, se pondera sobre as alternativas existentes e se investe em um curso de ação. O modelo de Hilton (JEPSEN; DILLEY, 1974) remete a um modelo descritivo de Tomada de Decisão, centra-se nos mecanismos de processo de informação, nas premissas que definem crenças ou expectativas acerca do self e do mundo, nos planos que correspondem a sequencia de ações associadas à escolha de uma profissão e a dissonância cognitivas.

Este processo de decisão, descritivo, inicia-se a partir de um input ou estímulo do ambiente que modifica os planos do decisor. O decisor testa a informação de forma a verificar se provocou dissonância. Caso esta ocorra, o decisor deve explorar a informação relevante relacionada com outro plano de ação.

Peterson, Sampson e Readon(1991) neste mesmo modelo descritivo, afirmam que a tomada de decisão envolve um processo cíclico de cinco fases: a Comunicação, as Análises, a Síntese, a Avaliação e a Execução. Neste processo, ainda, encontra-se implicada a metacognição e a disponibilidade do indivíduo (capacidade de fazer escolhas). Os autores a definem como uma conversão da cognição em ação.

Já os modelos prescritivos, baseiam-se na decisão por si só e na escolha vocacional/profissional, estes se caracterizando por serem modelos de ajuda aos sujeitos ao longo de seu processo de tomada de decisão, tendo como a principal meta, a diminuição dos erros de escolha. (JEPSEN; DILLEY, 1974). Desta forma, o modelo prescritivo compara o decisor a um cientista, que irá buscar a informação necessária para o processo de tomada de decisão, baseando-se em estratégias de tomada de decisão como os métodos científicos, matemáticos e econômicos.

Neste modelo Gelatt (1962 apud JEPSEN E DILLEY, 1974) defende que a tomada de decisão deve ser avaliada a partir do processo e não do resultado, e ainda, considera que o processo de tomada de decisão envolve ciclos sucessivos de decisões experimentais, as quais ocorrem quando o indivíduo processa diferentes tipos de informações. Desta forma, o processo de tomada de decisão é descrito como um processo cognitivo, baseado em método científico que implica em três sistemas de avaliação: (1) sistema preditivo, que reúne informação relativa às ações possíveis, aos resultados possíveis dessas ações, e à probabilidade dos resultados; (2) um sistema de valores, relativo às preferências entre 
resultados prováveis e (3) e um sistema de decisão, que diz respeito à avaliação que o sujeito faz das prioridades ou regras.

Gelatt (1962) afirma que o sujeito deve explorar informação precisa e completa acerca de todos os sistemas, para então ser capaz de antecipar os riscos da implementação de cada uma das opções a serem consideradas. Mas, a teoria e investigação contrariam esta ideia, demonstrando que as pessoas tendem a serem cautelosas no processo de decisão, centrando-se muitas vezes em pequenas unidades de informação que se relacionam diretamente com o problema (Taveira, 2000).

Autores como Gati (1996) defendem que uma "boa" decisão é a que se refere ao processo de escolha, enquanto um "bom resultado" diz respeito à desejabilidade do resultado da decisão tomada. Este autor também apresenta um modelo prescritivo, denominado de Modelo de Eliminação Sequencial (Sequential Elimination Model) de aspectos e atributos relativos às opções, divido pelas seguintes fases: (1) identificar aspectos relevantes, (2) hierarquizar as alternativas, tendo em conta os aspectos considerados, (3) identificar o nível de importância das alternativas, tendo como base o aspecto mais importante considerado, (4) eliminar as alternativas que não preenchem o nível aceitável anteriormente considerado, e (5) verificar a extensão da lista de alternativas daí resultantes.

No que tange aos modelos normativos da decisão vocacional, estes têm como principal objetivo, desenvolver procedimentos para a realização de "boas" escolhas ou decisões “ótimas”. Estes modelos baseiam-se na avaliação de alternativas possíveis para o indivíduo, utilizando para o efeito duas variáveis: (1) a utilidade subjetiva, isto é, o valor que o sujeito atribui a cada uma das alternativas, e (2) probabilidade prevista, ou seja, a ideia que a escolha de uma ação específica leva a um determinado resultado. $\mathrm{Na}$ verdade, nestes modelos compartilha-se a suposição que as vantagens percebidas de uma alternativa, podem compensar as desvantagens percebidas da mesma alternativa, o que leva a que estes modelos normativos sejam rotulados como modelos compensatórios (Compensatory Models) (ZAKA; BARACK, 1984).

De acordo com os modelos descritos anteriormente, pode-se referir que os modelos normativos trabalham com assunções matemáticas, mas tal como Gati e cols. (2008, p. 164) afirmam, estes modelos trabalham premissas filosóficas e psicológicas. $\mathrm{Na}$ verdade, os modelos baseiam-se na premissa de que os indivíduos são decisores racionais, procurando alternativas que demonstram ser mais benéficas, reunindo toda a informação relativa a cada alternativa, considerando assim os vários cenários possíveis da escolha de cada uma das 
alternativas. O indivíduo cria assim uma alternativa composta, isto é, estima o valor de cada alternativa, reunindo todas as vantagens/benefícios e criando uma nova alternativa.

A partir desta breve descrição de modelos de tomada de decisão vocacional, podemos afirmar, que apesar da evolução do conceito de tomada de decisão de carreira, que atualmente, diante à diversidade de situações de escolha e à crescente imprevisibilidade das trajetórias profissionais que, em geral, os indivíduos não se comportam com base em abordagens prescritivas à tomada de decisão (GATI; OSIPOW,1996). Embora possamos afirmar, ainda, que os vários modelos de tomada de decisão são complementares, na medida em que seguem objetivos distintos.

\subsection{A tomada de decisão de carreira e o modelo proposto por Itamar Gati e seus colaboradores.}

A investigação sobre a indecisão de carreira constitui uma das áreas importantes de investigação no campo da Psicologia Vocacional (OSIPOW, 1999). Tal como referido anteriormente, ao longo da vida, as pessoas são chamadas a tomar vários tipos de decisões. Muitas vezes, estes momentos geram uma ativação da ansiedade e a percepção de risco (GATI; KRAUSZ;OSIPOW, 1996).

Assim, projetar decisões e comprometer-se com elas, e agir adequadamente, surgem como dois desafios interligados, em diferentes momentos da vida, na adolescência, adultez jovem, na fase adulta e no envelhecimento. Para muitos jovens, é durante a adolescência que se encara pela primeira vez e de modo mais autônomo e independente, a tomada de uma decisão relacionada com a carreira (SUPER, 1991; TAVEIRA, 2006).

Na literatura, o estudo da tomada de decisão desenvolveu-se a partir dos modelos já enunciados e também, empiricamente, através da análise de fenômenos como a indecisão vocacional (VIOLA, 2008), encarada como a incapacidade para escolher uma profissão ou formação. Atualmente existe alguma indefinição quanto ao construto de indecisão vocacional. Apesar disso, Saka e Gati (2007) definem a indecisão como "as dificuldades encontradas no momento de tomar decisões relacionadas com a carreira", o que pode contribuir para alcançar um consenso a este nível. Segundo um conjunto de estudos empíricos, indivíduos com indecisão generalizada apresentam um nível superior de traços de personalidade negativos, como o neuroticismo, a instabilidade global e um estado de ansiedade elevado (FISCHER; SUBICH, 1998). 
Gati, Krauz e Osipow (1996) construíram um modelo de tomada de decisão, que denominam de modelo de "decisor ideal". Este modelo define a existência de um decisor que está consciente da necessidade de tomar uma decisão vocacional e devendo esta ser baseada nos seus objetivos. O indivíduo deve demonstrar vontade para tomar a decisão da forma mais correta. Segundo os autores, este é um processo complexo, acarretando um elevado grau de dificuldade para o indivíduo em tornar-se um "decisor ideal". Com isto, Gati e col. (1996), definiram que qualquer desvio a este processo deve ser entendido como um potencial problema que pode afetar o indivíduo de duas formas: na tomada de decisão, ou leva a uma tomada de decisão inadequada (GATI, 1996)

Assim, a tomada de decisão de carreira é caracterizada por uma situação na qual o indivíduo tem de tomar uma decisão. Todos estes aspectos são comuns na tomada de decisão de carreira que se realiza ao longo da vida, para isso foi necessário encontrar características únicas no processo de tomada de decisão de carreira, como o fato de existir um número elevado de alternativas; a quantidade elevada de informação que cada uma das alternativas reúne, bem como a quantidade de aspectos para caracterizar cada uma das ocupações e preferências do indivíduo (GATI et al., 1996; 2008).

Gati e colaboradores (1996) iniciaram o processo de identificação das dificuldades que impossibilitam o indivíduo tomar uma decisão. A taxionomia destes autores foi desenvolvida por meio de uma interação entre as dificuldades encontradas na teoria e nos estudos empíricos. De forma, a aumentar o grau de compreensibilidade desta taxionomia e a sua aplicabilidade aos contextos reais, os autores recolheram descrições de várias dificuldades na tomada de decisão encontradas por duzentos conselheiros de carreira e dez psicólogos especializados em Orientação Vocacional. Para garantir que todas as dificuldades tinham sido incluídas no questionário, os mesmos cruzaram a informação recolhida com os modelos teóricos existentes. Durante este processo, foram introduzidas algumas alterações nos grupos de dificuldades que fazem parte das subcategorias. Assim, depois de reverem os principais modelos de decisão e taxionomias de problemas associados à escolha e desenvolvimento de carreira, Gati e colaboradores (1996) propõem uma representação hierárquica das dificuldades de decisão de carreira.

Uma das inovações desse modelo refere-se ao fato de reunir resultados provenientes de duas linhas de investigação conduzidas de forma separada: um linha teórica, sem recurso a estudos empíricos e outra com preocupações predominantemente de caráter empírico na tentativa de construir medidas de indecisão de carreira (GATI et al., 1996; OSIPOW, 1999). 
Desta forma, os autores criaram um instrumento psicométrico, que surgiu com o intuito de relacionar a investigação acerca da indecisão de carreira com o processo de tomada de decisão e de apresentar um novo modelo teórico das dificuldades de tomada de decisão de carreira baseado numa adaptação da teoria de decisão ao contexto das decisões de carreira (GATI ET AL., 1996A; GATI,OSIPOW, KRAUSZ, \& SAKA,2000).

Para a construção da taxionomia e baseado na teoria de decisão os autores partiram de um modelo que postula as condições ideais para a tomada de decisão de carreira. Este modelo do "decisor ideal" reporta-se a um sujeito que: (a) está ciente da necessidade de tomar uma decisão de carreira; (b) está disposto a tomá-la; e (c) é capaz de tomar uma boa decisão o que implica a utilização de um processo apropriado e compatível com os seus objetivos. Seguidamente, aqueles autores definiram que qualquer desvio destas condições ideais constitui um potencial problema para o processo de tomada de decisão do indivíduo que pode afetar este processo de duas maneiras possíveis: (a) impede o sujeito de tomar a decisão ou (b) conduz a uma decisão que não é a ideal (GATI et al., 1996, 2000).

De acordo com diferentes autores o processo de tomada de decisão pode ser separado em componentes distintos e cada uma pode implicar diferentes tipos de dificuldades. Assim sendo, as diferentes dificuldades que potencialmente um indivíduo pode enfrentar durante o processo de tomada de decisão podem ser classificados em categorias distintas. Dificuldades com características comuns podem ser incluídas na mesma categoria (GATI, 1996).

As dificuldades da tomada de decisão de carreira foram classificadas em diferentes categorias tendo em conta os seguintes critérios: 1) o momento em que surgem (antes ou durante o processo de tomada de decisão da carreira), 2) a fonte da dificuldade (cognitiva ou afetiva), 3) o impacto da dificuldade na decisão (bloqueio do processo ou impacto na qualidade da decisão), 4) o tipo de intervenção requerido para superar a dificuldade. Um sujeito pode apresentar uma única dificuldade ou um conjunto delas, estas que podem pertencer a uma única ou a diversas categorias (GATI, 1996).

O modelo final inclui três categorias principais de dificuldades: Falta de Prontidão, Falta de Informação e Informação Inconsistente. Cada uma destas categorias principais divide-se em categorias específicas de dificuldades, sendo dez no total.

$\mathrm{Na}$ taxionomia teórica das dificuldades de tomada de decisão de carreira. A categoria principal Falta de Prontidão situa-se antes do início do processo e comporta três categorias de dificuldades: (a) Falta de Motivação para se envolver no processo; (b) Indecisão Generalizada perante todo o tipo de tomada de decisão; e (c) Crenças Disfuncionais acerca a tomada de decisão de carreira. As outras duas categorias principais: Falta de Informação e Informação 
Inconsistente referem-se a dificuldades que podem surgir durante o processo de tomada de decisão. A primeira inclui as categorias (a) Falta de Informação acerca do Processo de Tomada de Decisão; (b) do Self; (c) das Ocupações e (d) de Fontes Adicionaiis de Informação (GATI; OSIPOW, 2000). A categoria principal Informação Inconsistente é composta por três categorias de dificuldades e inclui: (a) Informação pouco Fidedigna; (b) Conflitos Internos; e (c) Conflitos Externos. A Figura 1 ilustra a estrutura da taxionomia descrita.

\section{CAREER DECISION MAKING DIFFICULTIES}

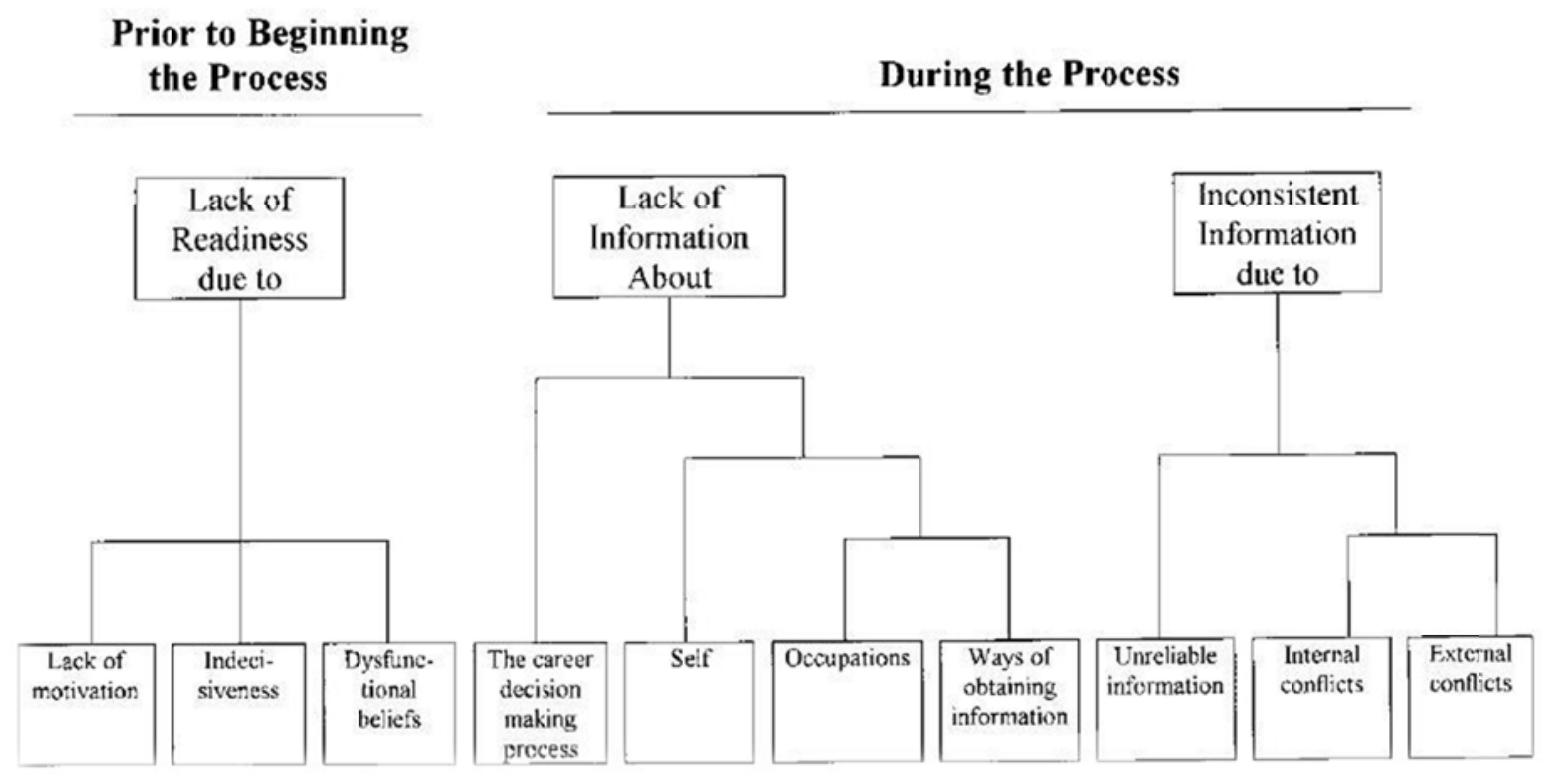

Figura 1 - Teoria taxonômica das dificuldades na tomada de decisão para a carreira. (GATI, OSIPOW, KRAUSZ, \& SAKA, 2000)

As dificuldades foram divididas em dois grupos principais: aquelas existentes antes do início da escolha e as existentes durante a escolha. Como mostra a Figura 1, as dificuldades antes do início da escolha referem-se à imaturidade geral em relação à decisão profissional. As dificuldades vividas durante o processo referem-se basicamente à insuficiência de informações consistentes, tanto sobre si mesmo quanto sobre as áreas profissionais, dificultando a decisão segundo o critério de utilidade.

A estrutura teórica da taxionomia das dificuldades de tomada de decisão mantem-se inalterada. Contudo varia o número de itens, tanto do questionário total como das diversas escalas que o compõem, apresentando a versão atual CCDQ (GATI ; SAKA , 2001) um total 
de 34 itens em comparação com os 44 itens propostos na versão original de Gati e colaboradores (1996).

Numa primeira fase, separam as dificuldades que podem ocorrer antes do início do processo de decisão, e as que surgem durante o processo de decisão. Numa segunda fase, diferem três categorias principais de dificuldades: a Falta de Prontidão, a Falta de Informação e a Informação Inconsistente. Estas duas últimas categorias principais referem-se a dificuldades que podem advir durante o processo de tomada de decisão, enquanto, que a primeira categoria remete para as dificuldades que têm lugar antes do processo de decisão ter início. Num terceiro nível, encontram-se representadas dez categorias específicas de dificuldades, estas são apresentados no Quadro 1.

Quadro 2 - Quadro da Taxionomia de dificuldades de tomada de Decisão de Carreira de Gati e cols (1996).

\begin{tabular}{|c|c|c|}
\hline Processo & Categoria Principal & Subcategoria \\
\hline \multirow{3}{*}{$\begin{array}{l}\text { Antes do Processo de } \\
\text { Tomada de Decisão }\end{array}$} & \multirow[t]{3}{*}{ Falta de Prontidão } & Falta de Motivação \\
\hline & & Indecisão Generalizada \\
\hline & & Crenças Disfuncionais \\
\hline \multirow[t]{4}{*}{$\begin{array}{l}\text { Durante o Processo de } \\
\text { Tomada de Decisão }\end{array}$} & \multirow[t]{4}{*}{ Falta de Informação } & $\begin{array}{l}\text { Falta de Informação sobre o Processo de Tomada } \\
\text { de Decisão de Carreira }\end{array}$ \\
\hline & & Falta de Informação acerca do Self \\
\hline & & $\begin{array}{l}\text { Falta de Informação acerca das } \\
\text { Profissões/Ocupações }\end{array}$ \\
\hline & & Falta de informação de fontes adicionais \\
\hline \multirow{3}{*}{$\begin{array}{l}\text { Durante o Processo de } \\
\text { Tomada de Decisão }\end{array}$} & \multirow[t]{3}{*}{ Informação Inconsistente } & Informação pouco fidedigna \\
\hline & & Conflitos internos \\
\hline & & Conflitos externos \\
\hline
\end{tabular}

Inserida na categoria principal "Falta de Prontidão", do modelo taxinômico revisto, encontram-se três categorias específicas: a Falta de Motivação, a Indecisão Generalizada e as Crenças Disfuncionais. Estas três subcategorias refletem, respectivamente pela ordem que foram apresentadas, as dificuldades devidas à falta de motivação para se implicar no processo de decisão, indecisão generalizada a respeito de todos os tipos de tomada de decisão e crenças disfuncionais acerca da decisão de carreira. A categoria "Falta de Informação" abrange quatro subcategorias: Falta de Informação acerca do Processo de Tomada de Decisão de Carreira (acerca dos passos), Falta de Informação acerca do Self, Falta de Informação acerca das 
Profissões/Ocupações, e Falta de Informação de fontes adicionais. E finalmente, a categoria principal "Informação Inconsistente", inclui três subcategorias: Informação pouco fidedigna, Conflitos Internos e Conflitos Externos - que envolve conflitos com outros significativos da vida do indivíduo. Gati e col. (1996) construíram para além das três categorias principais e das dez subcategorias, um modelo teórico através de 44 dificuldades específicas, representativas das categorias e subcategorias da taxionomia.

Essa taxionomia foi transformada em um Questionário o Career Decision-making Difficulties Questionnaire (CDDQ), na sua versão original foi construído por Gati e colaboradores (1996), para investigar empiricamente a validade da taxionomia teórica das dificuldades relacionadas com o processo de tomada de decisão de carreira, anteriormente descrita. Trata-se de uma ferramenta psicométrica que permite que cada pessoa se autoavalie em cada uma das quarenta e quatro dificuldades específicas propostas pelos autores, numa escala tipo Likert de nove pontos ( 1 = Não me descreve; 9 = Descreve-me bem).

O instrumento surgiu com o intuito de relacionar a investigação acerca da indecisão de carreira com o processo de tomada de decisão e de apresentar um novo modelo teórico das dificuldades de tomada de decisão de carreira baseado numa adaptação da teoria de decisão ao contexto das decisões de carreira (GATI et al., 1996; GATI; OSIPOW; KRAUSZ; SAKA, 2000).

Para a interpretação dos resultados é possível calcular médias para as três categorias principais bem como o Total do questionário que representa a média das dez escalas. No CDDQ, todos os itens do questionário são apresentados em forma de afirmação e respondidos, como citado, em formato tipo Likert com nove pontos (de 1 a 9) no qual os extremos da escala correspondem respectivamente ao posicionamento "não me descreve" para o valor mais baixo e "descreve-me bem" para o ponto mais elevado da escala.

A categoria principal Prontidão/Estar apto para a Tomada de Decisão inclui, como já foi referido, três categorias de dificuldades: (a) FM=Falta de Motivação (3 itens); (b) IG=Indecisão Generalizada (3 itens); e (c) CD=Crenças Disfuncionais (4 itens).

Na primeira escala Dificuldades Generalizadas para tomar decisões na segunda e uma percepção distorcida acerca do processo de tomada de decisão de carreira, expectativas irracionais ou pensamentos disfuncionais no que se refere à escala Crenças Disfuncionais (GATI et al., 1996).

A categoria principal Falta de Informação é composta por quatro categorias de dificuldades específicas: (a) EPTD= Processo de Tomada de Decisão (3 itens); (b) S=Self (4 
itens); (c) $\mathrm{OC}=$ Ocupações/ Profissões (3 itens) e (d) MIA= de Fontes Adicionais de Informação (2 itens).

Quanto à escala Processo de Tomada de Decisão, um resultado elevado reflete a falta de conhecimento acerca da forma como tomar uma decisão de modo sensato e especificamente falta de conhecimento acerca dos passos envolvidos no processo de tomada de decisão. Um resultado elevado na escala Self reflete uma situação em que o sujeito sente que não é detentor de informação suficiente acerca de si próprio. Na escala Ocupações, pontuações altas são indicadoras de uma situação na qual a pessoa não detém informação suficiente acerca das opções ocupacionais existentes, o tipo de alternativas existentes e/ou as suas características. Um resultado elevado na última escala desta categoria principal, Fontes Adicionais de Informação, reflete uma lacuna na informação relativamente às formas de obter informação adicional ou no que respeita as ajudas existentes que podem facilitar a tomada de decisão (GATI,1996).

A categoria principal Dificuldades devidas a Informação Inconsistente, comporta as categorias de dificuldades (a) IPF= Informação pouco Fidedigna (3 itens); (b) $\mathrm{CI}=$ Conflitos Internos (5 itens); e (c) $\mathrm{CE}=$ Conflitos Externos ( 2 itens). Resultados elevados na escala IPF indicam que o sujeito sente que a informação de que dispõe acerca de si próprio ou das profissões que considera contém contradições. Pontuações altas, na escala Conflitos Internos e Conflitos externos refletem um estado de confusão interna. Este conflito pode ser resultado de dificuldades em encontrar um compromisso entre seu mundo interno e as necessidades do mundo externo. O Quadro 2 mostra a forma de cotação dos dados e as questões que compõe cada categoria e escala. 
Quadro 2 - Quadro das categorias principais organizadas em escalas e os números de itens do CDDQ.

\begin{tabular}{|l|l|}
\hline \multicolumn{1}{|c|}{ As escalas } & \multicolumn{1}{|c|}{ Itens do Questionário } \\
\hline Prontidão/Estar apto para a Tomada de Decisão & $1-3$ \\
(1) FM - Falta de Motivação & $4-6$ \\
(2) IG - Indecisão Generalizada & $8-11$ \\
(3) CD - Crenças Disfuncionais & \\
\hline Falta de Informação acerca de & $13-15$ \\
(4) EPTD-Processo de Tomada de Decisão & $16-19$ \\
(5) S-Self & $20-22$ \\
(6) OC-Ocupações/Profissões & $23-24$ \\
(7) MIA- de fontes adicionais de informação & $25-27$ \\
\hline Dificuldades devidas a Informação Inconsistente & $28-32$ \\
(8) IPF-Informação pouco fidedigna & $33-34$ \\
(9) CI-Conflitos Internos & \\
(10) CE - Conflitos Externos & \\
\hline
\end{tabular}

A seguir são apresentadas a significação de cada escala presente no Quadro 2, e o que os valores elevados podem indicar em termos de interpretabilidade, (GATI, KRAUSZ, \& OSIPOW. A taxonomy of difficulties in carrer decision making, 1996).

A significação de cada escala, e o que os valores elevados podem indicar em termos de interpretabilidade da escala (GATI; KRAUSZ; OSIPOW, 1996) são descritos a seguir.

(1) Falta de motivação. Um resultado elevado nesta área reflete falta de vontade para tomar uma decisão nesta fase da vida. Isto poderá indicar que não quer tomar a decisão neste momento, ou que possui a crença "Não é necessário investir tempo e esforço a tomar uma decisão de carreira, uma vez que o tempo acabará por me levar a tomar a decisão mais certa".

(2) Indecisão generalizada. Um resultado elevado nesta área reflete um estado de dificuldade generalizada em tomar decisões. Algumas pessoas tendem a ser indecisas em várias áreas da sua vida. As indecisões estão normalmente associadas a hesitação, medo de 
falhar ou medo de comprometer-se. As pessoas que são indecisas de uma forma generalizada podem adiar uma decisão ou mudar constantemente de opinião, até chegar o momento de decidir. Às vezes precisam que outras pessoas confirmem a sua decisão para sentirem que tomaram a decisão correta.

(3) Crenças disfuncionais. Refere-se às crenças ou expectativas irracionais acerca das decisões de carreira. Um resultado elevado nesta área reflete uma percepção distorcida do processo de tomada de decisão de carreira. Crenças e expectativas irracionais acerca de decisões de carreira, como por exemplo, a crença "só se faz uma escolha de carreira uma vez na vida", ou "a escolha de uma carreira é um compromisso para a vida" ou ainda "aquela profissão/ocupação poderá preencher todas as minhas aspirações, como pessoa", que poderão afetar negativamente ou impedir o processo de tomada de decisão.

(4) Falta de informação acerca do processo de tomada de decisão. Um resultado elevado nesta área reflete a falta de conhecimento acerca da forma como se poderá chegar sensatamente a uma decisão e, especificamente, dos passos envolvidos no processo de tomada de decisão de carreira. Por exemplo: uma pessoa poderá não saber que fatores ter em conta, ou ter dificuldades em combinar a informação que detém sobre ela própria (pontos fortes e menos fortes) e a informação que detém acerca das diversas opções ocupacionais (que capacidades são requeridas numa ocupação específica).

(5) Falta de informação acerca do Self . Um resultado elevado nesta área reflete uma situação em que uma pessoa sente que não detém informação suficiente acerca de si própria. Poderá não saber o que quer (que condições de trabalho prefere ou se é suficientemente talentoso numa área, ou se possui determinados traços de personalidade que são considerados “críticos” ou essenciais numa determinada ocupação).

(6) Falta de informação acerca das profissões. Um resultado elevado nesta área reflete uma situação em que uma pessoa não detém informação suficiente acerca das opções ocupacionais: que alternativas há e/ou em que consiste cada alternativa.

(7) Falta de informação acerca de fontes adicionais de informação. Um resultado elevado nesta área reflete falta de informação sobre meios de informação adicional ou meios para facilitar a tomada de decisão. Por exemplo: uma pessoa poderá não saber onde procurar informação acerca das profissões ou onde procurar aconselhamento psicológico vocacional.

Informação pouco fidedigna. Um resultado elevado nesta área indica que a pessoa sente que a informação que detém acerca dela ou acerca das profissões que considera contém contradições. Por exemplo, poderá haver contradições entre a forma como uma pessoa se vê e a forma como os outros a veem, ou entre a informação objetiva e subjetiva (por 
exemplo: se o professor de artes considera que os desenhos ou pinturas são maravilhosos quando uma pessoa os acha medíocres).

(9) Conflitos internos. Um resultado elevado nesta área reflete um estado de confusão interna. Este conflito poderá derivar de uma determinada dificuldade de compromisso com os vários fatores que uma pessoa considera como importantes na tomada de decisão. Por exemplo: uma pessoa foi aprovada em uma universidade, mas o seu companheiro vive em uma cidade diferente. Os conflitos internos também poderão surgir quando uma ocupação atrativa envolve um aspecto nada atrativo (tal como a duração de um curso e a prática necessária para se tornar um médico), ou ainda quando várias ocupações são igualmente atrativas para a pessoa.

(10) Conflitos externos. Um resultado elevado nesta área indica um fosso entre as preferências de uma pessoa e aquelas verbalizadas por outros significativos, ou entre a opinião de duas pessoas significativas. Os conflitos externos surgem quando se decide tomar determinados aspectos em consideração ou escolher uma determinada ocupação, quando outras pessoas significativas têm outras preferências. Por exemplo: uma pessoa poderá preferir uma ocupação que requer uma preparação relativamente curta, enquanto os pais preferem que essa pessoa escolha uma carreira acadêmica.

Com base nesse modelo e questionário muitas pesquisas têm-se desenvolvido utilizando-se do questionário para avaliar suas qualidades psicométricas bem como estudar a área de Tomada de Decisão e indecisão no âmbito da Psicologia Vocacional. A próxima seção tem como objetivo explanar as principais qualidades psicométricas relatadas em pesquisas, citando alguns estudos de validação do CDDQ.

\subsection{Estudos de validação do Questionário de Dificuldades de Tomada de Decisão para a Carreira.}

Silva (2004) refere-se ao CDDQ como um dos principais instrumentos de avaliação da indecisão profissional em âmbito internacional. Ainda salienta que o CDDQ, em fase experimental, apresenta diversas potencialidades e pontos de interesses para psicólogos e investigadores. $\mathrm{O}$ referido autor considera esse instrumento como uma ferramenta inovadora para realização de investigações, teoricamente apoiado sobre o processo de indecisão na carreira. Salienta que o questionário (CDDQ) na prática da Orientação Profissional poderá revelar-se particularmente adequado para realização de um diagnóstico diferencial das 
dificuldades de decisão sobre carreiras, fornecendo indicadores para o delineamento de estratégias de intervenção.

Diversos estudos de validade dão suporte à taxionomia presente no questionário (GATI; OSIPOW; KRAUSZ; SAKA, 2000; GATI; SAKA, 2001; KELLY; LEE, 2002; LANCASTER; RUDOLPH; PERKINS,; PATTEN, 1999; MAU, 2001;)

Inicialmente, o estudo da confiabilidade do CDDQ foi realizado em dois grupos diferentes, um em Israel e o outro nos Estados Unidos (GATI; KRAUSZ; OSIPOW, 1996). $\mathrm{Na}$ amostra israelense, o coeficiente alfa de Cronbach mediano foi de 0.78 e o coeficiente teste-reteste foi de 0.65. Já na amostra norte-americana, a consistência interna foi de 0.77 . Para o resultado Total do CDDQ, o alfa de Cronbach foi de 0.95, em ambas as amostras. Estudos realizados posteriormente, como podem ser observados na Tabela 1 e na Tabela 2, têm revelado valores similares. Existem evidências que a maioria dos valores, de consistência interna, está localizada num intervalo que vai de moderado a elevado, para maioria das escalas, com exceção da escala de Crenças Disfuncionais (que afeta diretamente o fator Prontidão). Esta escala tem se revelado em quase todos os estudos baixa confiabilidade. Osipow e Gati (1998) propuseram que esta baixa confiabilidade poderia estar associada ao pequeno número de questões que compõem esta escala. Em um estudo recente (GATI e SAKA, 2001) abordaram de forma empírica esta questão, aumentando o número de itens desta escala, o que gerou um resultado mais elevado.

Na sequência, Osipow e Gati (1998) realizaram pesquisa com uma amostra de 403 estudantes americanos com idade média de 16,7 anos e encontraram correlações ente o CDDQ e o CDS (Escala de Decisão de Carreira) encontrando correlação de 0,77. Além do CDS os autores realizaram análises de correlação entre o CDDQ e o CDMSE (Questionário de Decisão na Carreira e Autoeficácia), que se apresentou, como esperado, com correlação negativa de -0,5. Nesse estudo o CDDQ apresentou escores mais elevados nos resultados com estudantes que não haviam ainda tomado uma decisão.

Gati, Osipow, Krausz e Saka (2000), buscando validade por critério, contaram com o auxílio de 95 conselheiros com ampla experiência em orientação profissional, que julgavam seus orientandos de acordo com as respostas dos questionários: a correlação média foi de 0,49. Por sua vez, Mau (2001) com uma amostra americana $(\mathrm{N}=514)$ e taiwanesa $(\mathrm{N}=947)$, ao submeter os resultados do questionário à análise fatorial encontrou semelhança entre as estruturas das dificuldades do questionário e a estrutura teórica nas duas amostras.

A Tabela 1 apresenta de forma mais clara, resultados encontrados em sete estudos de confiabilidade . 
Tabela 1 - Estudos de confiabilidade do CDDQ.

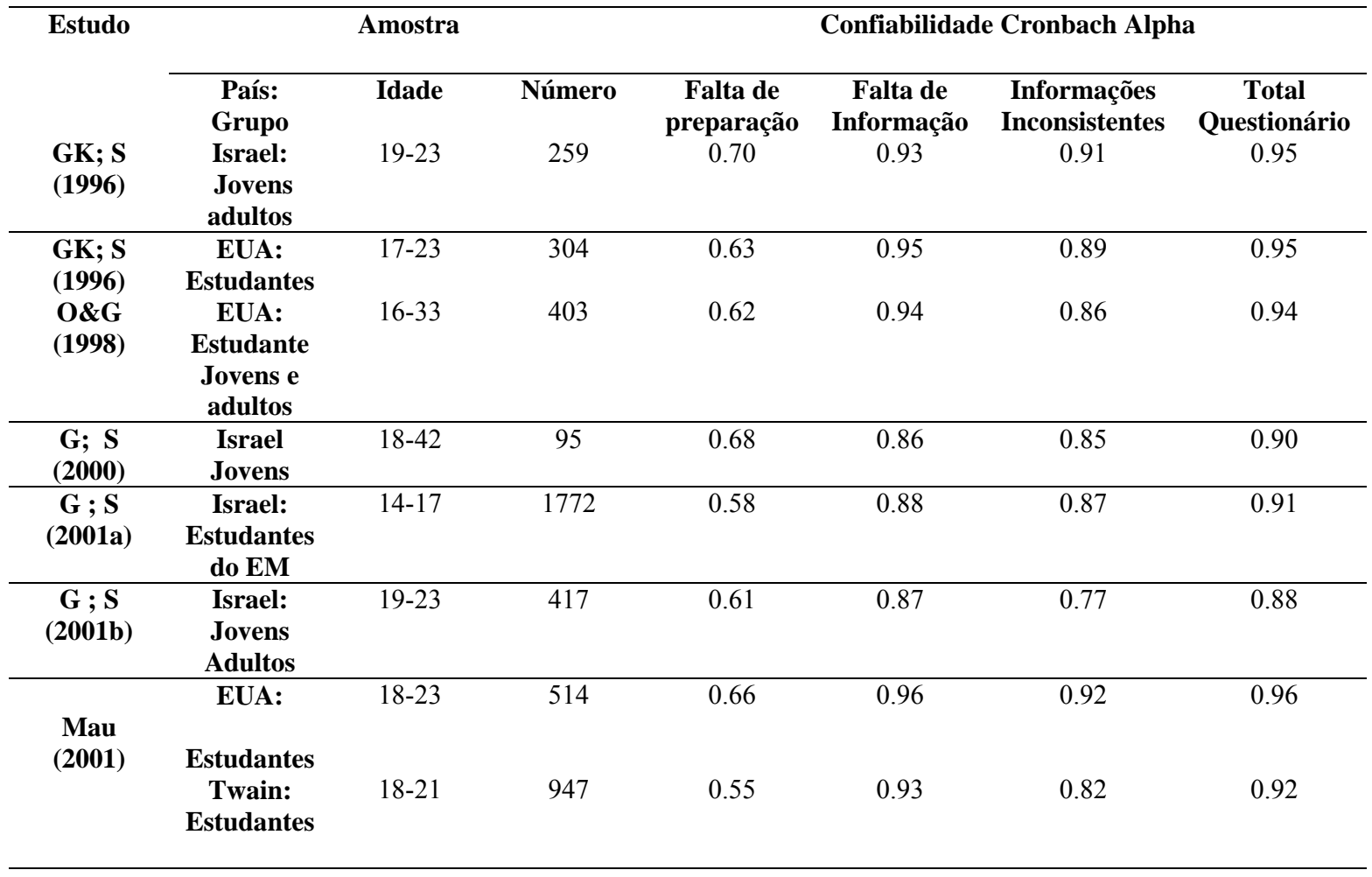

Já a Tabela 2 , apresenta 3 estudos que comprovam a confiabilidade atráves de testereteste.

Tabela 2 - Estudos de teste-reteste do CDDQ.

\begin{tabular}{|c|c|c|c|c|c|c|c|}
\hline \multirow[t]{2}{*}{ Estudo } & \multicolumn{3}{|c|}{ Amostra } & \multicolumn{4}{|c|}{ Confiabilidade teste-reteste } \\
\hline & Grupo & Idade & Número & $\begin{array}{c}\text { Falta de } \\
\text { preparação }\end{array}$ & $\begin{array}{c}\text { Falta de } \\
\text { Informação }\end{array}$ & $\begin{array}{c}\text { Informações } \\
\text { Inconsistentes }\end{array}$ & $\begin{array}{c}\text { Total } \\
\text { Questionário }\end{array}$ \\
\hline $\begin{array}{l}\text { GK; S } \\
\text { (1996) }\end{array}$ & $\begin{array}{c}\text { Israel: } \\
\text { Jovens } \\
\text { Adultos }\end{array}$ & $19-23$ & 259 & 0.67 & 0.74 & 0.72 & $\mathbf{0 . 8 0}$ \\
\hline $\begin{array}{c}\text { G ; S } \\
(2001 b)\end{array}$ & $\begin{array}{c}\text { Israel: } \\
\text { Jovens } \\
\text { Adultos }\end{array}$ & $19-23$ & 417 & 0.81 & 0.69 & 0.75 & 0.79 \\
\hline $\begin{array}{l}\text { Mau } \\
(2001)\end{array}$ & $\begin{array}{l}\text { Taiwan: } \\
\text { Estudantes }\end{array}$ & - & 93 & 0.56 & 0.85 & 0.78 & - \\
\hline
\end{tabular}

Quanto à confiabilidade dos resultados, observando a consistência interna e os dados do teste-reteste (Tabela 1 e 2), os resultados obtidos são em sua maioria bons, embora algumas escalas devam ser tratadas com cautela.

Seguindo so estudos para validação nos em diferentes países, Loureiro e Taveira (2010) desenvolveram um estudo com o objetivo de explorar as qualidades psicométricas da 
versão em português do Questionário de Dificuldades de Tomada de Decisão de Carreira (GATI; SAKA 2001) para utilização num estudo sobre a avaliação daquele tipo de dificuldades no âmbito de uma intervenção na gestão pessoal da carreira de alunos do Ensino Superior. A amostra do referido estudo é composta por 163 alunos de graduação de ambos os sexos (22 rapazes e 141 moças), com idades compreendidas entre os 19 e os 40 anos $(\mathrm{M}=22,69 ; \mathrm{DP}=3,50)$ de três estabelecimentos de Ensino Superior do norte de Portugal. Como principais resultados, foram apresentados, os valores dos coeficientes de consistência interna elevados, para as escalas, subescalas e total do CDDQ $(>0,70)$, com 0,90 na escala Falta de Prontidão, 0,92 na subescala Crenças Disfuncionais, e 0,89 na escala do total do CDDQ. Através da análise de componentes principais de 32 itens do CDDQ34 (depois de retirados os itens 7 e 12, de validade), aquelas autoras escolheram uma solução final de quatro fatores, que explicam $49,4 \%$ da variância dos resultados. O Fator 1 é constituído por todos os itens da escala Falta de Informação e pela subescala Conflitos Internos da escala Informação Inconsistente. $\mathrm{O}$ Fator 2 inclui todos os itens das subescalas Indecisão Generalizada e Conflitos Externos. O Fator 3 engloba todos os itens da subcategoria Crenças Disfuncionais. E o Fator 4 inclui todos os itens da subescala Falta de Motivação. Os valores dos coeficientes alfa de Cronbach (consistência interna) foram de 0,92 (Fator 1), de 0,68 (Fator 2), de 0,63 (Fator 4) e de 0,60 (Fator 3), respectivamente. Loureiro e Taveira (2010) concluíram que seria adequado prosseguir com a replicação deste estudo exploratório, com amostras mais alargadas de alunos do Ensino Superior.

Simões (2010), também para a realidade portuguesa, analisou as qualidades psicométricas e os resultados da versão portuguesa do Questionário de Dificuldades de Tomada de Decisão de Carreira, desenvolvida por Silva e colaboradores (SILVA, 2005). Com uma amostra de 271 alunos do $9^{\circ}$ ano de escolaridade, Braga e Barcelos [138 (50,9\%) moças e 132 (48,7\%) rapazes, com idades compreendidas entre os 13 e os 18 anos $(\mathrm{M}=14,4$; $\mathrm{DP}=0,78)]$. Encontrou na avaliação de confiabilidade dos itens do CDDQ uma consistência interna satisfatória, coeficiente de alfa de Cronbach de 0,92. Os resultados da análise de componentes principais e de consistência interna das dimensões do CDDQ34 indicaram uma solução de sete fatores, em que o coeficiente de alfa de Cronbach mais baixo é relativo ao Fator $7(0,56)$ e o mais alto diz respeito ao Fator $1(0.92)$, sendo que os demais fatores apresentam níveis de consistência com níveis entre 0,60 (Fator 4) e o 0,72 (Fator 2).

Com este mesmo objetivo de analisar características psicométricads do CDDQ em contextos internacionais, Ussene e Taveira (2010) verificaram as propriedades psicométricas do CDDQ e a aplicabilidade da versão portuguesa do CDDQ34 (GATI; SAKA, 2001; 
SILVA, 2005) em alunos da $12^{\mathrm{a}}$ classe, moçambicanos. A amostra desse estudo foi composta por 314 alunos, de escolas privadas e públicas da região sul de Moçambique, de ambos os sexos (194 moças e 120 rapazes), com idades compreendidas entre os 15 e os 24 anos $(\mathrm{M}=17,05 ; \mathrm{DP}=1,24)$. Em relação aos resultados, os referidos autores registraram, na primeira fase de exploração fatorial dos itens do CDDQ34, que as médias dos itens de resposta variam entre 3,51 e 6,51 pontos, e os desvios-padrão apresentam valores entre os 2,51 e 3,08 pontos. Em relação à consistência interna dos itens, Ussene e Taveira (2010) verificaram que estes apresentam coeficientes alfa de Cronbach muito satisfatórios, com valores entre 0,91 e 0,92. $\mathrm{Na}$ segunda fase de tratamento dos dados foi realizada a análise de componentes principais de 32 itens do CDDQ34 (depois de retirada dos itens de validade 7 e 12), alcançando-se uma solução fatorial de nove fatores interpretável, que explicam $65,60 \%$ da variância. O Fator 1 inclui os itens 19-24 da escala Falta de Informação e os itens 25-28 da escala Informação Inconsistente. O Fator 2 integra os itens 10 e 11 da escala Falta de Prontidão os itens 29, 31, 32 e 34 da escala Informação Inconsistente. O Fator 3 é composto pelos itens 27, 30 e 33 da categoria principal Informação Inconsistente. No Fator 4, saturam os itens 3-6 da escala Falta de Prontidão. O Fator 5 inclui os itens $15-17$ da categoria Falta de Informação. O Fator 6 engloba os itens 2 da escala Falta de Prontidão e o item 18 da categoria principal Falta de Informação. Por fim, o Fator 7 é composto pelos itens 8 e 9 da escala Falta de Prontidão; o Fator 8 pelos itens 1 da escala de dificuldades por falta de prontidão e o item 14 por Falta de Informação; e o Fator 9 pelo item 13 da escala Falta de Informação. Finalmente, foram registados neste estudo valores de coeficientes de alfa de Cronbach (consistência interna) de 0,61 para Falta de Prontidão, de 0,78 para a Falta de Informação, e de 0,81 para a Informação Inconsistente, e de 0,88 , para o total do CDDQ. As autoras concluem que é adequado considerar esta versão do CDDQ34, em um estudo mais definitivo sobre o tipo de dificuldades de tomada de decisão de carreira de estudantes moçambicanos, ainda que seja importante prosseguir a investigação da medida com novas amostras do mesmo país.

Como a população alvo deste estudo são universitários, buscou-se na literatuta estudos com o CDDQ que fossem realizados com esta população.

Apesar de o CDDQ ser utilizado, conforme literatura internacional, predominantemente com adolescentes de 14 a 18 anos na situação de transição do Ensino Médio para o Ensino Superior. A maior parte das pesquisas com esse questionário concentrase nessa faixa da população, porém a sua utilização em adultos e jovens adultos universitários vem ganhando destaque e obtendo êxito em sua utilização (KELLY; LEE, 2002). 
Kelly e Lee (2002) com o intuito de buscar os principais problemas apresentados no processo de tomada de decisão profissional utilizaram o CDDQ com 434 estudantes universitários do $1^{\circ}$ semestre, que teriam que optar por um curso específico no $4^{\circ}$ semestre. A idade média dos alunos foi de 18,07 ( $\mathrm{DP}=0,53)$. Realizaram análise fatorial e constataram que 6 fatores descreviam melhor o construto, e que este questionário poderia ser útil na tentativa de auxiliar aos universitários a tomada de decisão para o prosseguimento de seus estudos.

Kleiman e colaboradores (2004), com a população universitária norteamericana, aplicaram dois instrumentos em sua pesquisa (CDDQ e CTI- Career Thoughts Inventory). Participaram do estudo 109 mulheres e 93 homens, com média de 20,17 anos em um curso sobre planejamento de carreira. Os resultados evidenciaram uma correlação entre os dois instrumentos $(\mathrm{r}=0,82 \mathrm{p}<0,01)$. Segundo os autores, os dados sugeriram que os indivíduos que se sentem confusos quanto à tomada de decisão apresentam, com maior frequência, dificuldades relacionadas à Falta de Informação sobre o processo, sobre si mesmos e sobre as ocupações.

Como relatado, a maior parte dos estudos são realizados com estudantes do ensino médio,porém a utilização do questionário com universitários têm-se mostrado promissora, para o entendimento desta etapa educativa as subseções seguintes focará o entendimento dos processos de decisão ocorridos no E nsino Superior.

\subsection{As transições durante o Ensino Superior e o desenvolvimento de carreira.}

As transições pelas quais passam os estudantes do ensino superior são consideradas como um processo de mudança que acompanha o estudante durante todo o curso. No entanto, estas mudanças se intensificam em dois momentos do curso: logo no momento do ingresso na Educação Superior e posteriormente no final da graduação, na ocasião da transição da universidade para a vida profissional. A transição é entendida como "qualquer acontecimento ou não acontecimento que produza mudanças no nível dos relacionamentos, das rotinas, dos papéis do indivíduo ou possa afetar a ideia ou o conceito acerca de si e do mundo que o rodeia” (SCHLOSSBERG; WATERS; GOODMAN, 1995).

A transição que acontece na entrada no Ensino Superior é marcada principalmente pelos seguintes desafios: sair de casa, afastar-se da família, assumir novas funções e responsabilidades e atender às exigências de um novo grau de ensino. Assim, é necessário que o estudante se familiarize com uma nova situação. 
A transição que ocorre no final do ensino superior também é marcada por um momento em que o sujeito está em transição entre a adolescência e a vida adulta (ALMEIDA; SOARES, 2003). Esta é uma nova etapa da vida do indivíduo, na qual tem de assumir novas responsabilidades, anteriormente destinadas aos seus responsáveis, passando assim a ser condutor de sua vida, com responsabilidades financeiras e pessoais. Esse período é marcado pela iminência da formatura e inserção no mercado de trabalho, gerando grandes expectativas, ansiedade e insegurança (DEL PRETRE; DEL PRETE, 2003), além do sentido de alegria por ter concluído mais uma etapa da vida (OLIVEIRA, 2003). Este momento marca a saída de um ambiente que o estudante passou a conhecer, o ambiente do Ensino Superior, e o coloca frente aos desafios de um novo contexto, o mundo do trabalho, que é composto por novos tipos de relações e informações, principalmente exigindo habilidades sociais diferentes das desenvolvidas no âmbito do ensino superior (ALMEIDA; SOARES, 2003).

Bardagi (2004) aponta que algumas características do mercado e das instituições formadoras (escola, universidade) propiciam o estado de ansiedade e insegurança, especialmente a partir dos impasses gerados entre as competências acadêmicas desenvolvidas e as competências requeridas no mundo do trabalho contemporâneo. Por sua vez, para Teixeira (2002) a conclusão de um curso superior marca o fim de uma etapa na educação individual e carrega consigo uma série de expectativas que podem se tornar realidade ou não nos anos que se seguem.

Em uma investigação sobre a finalização do curso superior em uma instituição pública, Oliveira (2003) também identificou que a formatura em um curso de graduação representa, para a maioria dos alunos, a inserção no mercado de trabalho, caracterizado por um momento, às vezes perpassado por incertezas, dúvidas em relação a qual caminho seguir e demais sentimentos associados. É marcante, nesse período, as definições e as escolhas do direcionamento ou para uma vida acadêmica (com a realização da pós-graduação) ou para o ingresso no mercado de trabalho. A necessidade de tomar estas decisões $\mathrm{e}$ as responsabilidades atribuídas a estas tarefas parecem gerar nos alunos sentimentos negativos, medo e insegurança.

Os processos de transição podem ser entendidos sobre diferentes perspectivas. Schlossberg e Chickering (1995) consideram a transição como um acontecimento ou não que resulte em uma mudança ao nível das relações, das rotinas, dos papéis e dos ideais sobre si mesmo e o mundo circundante. A partir de tal conceito, as transições abrangeriam não somente as mais previsíveis (início da atividade profissional, casamento, finalizações de processos educativos), mas também mudanças mais sutis (promoção esperada, mas não 
concretizada, quebra de um percurso educacional). Desta forma, acontecimentos de vida ou um não acontecimento podem ser considerados momentos de transições, caso estes resultem em mudanças.

Campos (1993) refere que os acontecimentos da vida considerados como transições desenvolvimentais são as quais exigem uma mudança sobre os pressupostos, sobre si e sobre o mundo, o que requer do indivíduo mudanças no próprio comportamento e relações. As transições, de forma geral, exigem do indivíduo novos padrões de comportamentos.

O conceito de crise, que por vezes é associado a transições desenvolvimentistas, pode remeter a acontecimentos dramáticos, mas, sobre as perspectivas desenvolvimentistas, pode ser entendido sobre duas óticas. A primeira estaria relacionada ao aspecto negativo, na qual a situação de crise ocorre quando os mecanismos e padrões habituais que o indivíduo utiliza para lidar com situações problemáticas não são eficazes. Nesta perspectiva, o conceito de crise apresenta uma conotação negativa associada a perturbações psicopatológicas (SCHLOSSBERG; WATERS; GOODMAN, 1995). Por outro lado, a crise aconteceria quando o equilíbrio psicológico existente já não é o suficiente para sustentar as exigências atuais. Desta forma, é necessária uma reorganização pessoal e relacional. Assim a crise é vista como algo positivo, desejável, pois coloca o indivíduo frente a um desafio promotor do desenvolvimento. Esta perspectiva remeta a teoria psicossocial de Erikson (1987).

Segundo Campos (1993), “a transição tem sido utilizada para significar acontecimentos que a precipita, o processo de mudança que ocorre ou o resultado subsequente". Desta forma, podemos considerar que estamos perante uma transição desenvolvimental, "quando há acontecimentos de vida que põem em crise o sistema pessoal que exigem mudanças, constituindo assim tarefas de desenvolvimento" (CAMPOS, 1993, p 93).

De acordo com o modelo integrativo de transição (SCHLOSSBERG; WATERS;GOODMAN, 1995), o ponto de partida para uma transição pode ser conceitualizado como uma iniciação ou finalização de uma situação. A iniciação acontece quando o indivíduo se defronta com uma nova situação e necessita criar pautas para lidar com a nova forma, confronta-se com o novo papel e os outros papéis da vida. O ponto de partida de uma transição, como dito, pode ser uma finalização, quando o indivíduo abandona o contexto, pessoas ou formas de interagir que lhe são familiares.

Schlosserberg, Waters e Goodman (1995) apresentam um modelo de transição que engloba os elementos: a identificação da transição; a avaliação dos potenciais recursos para lidar com a transição; e o desenvolvimento dos recursos potenciais que a pessoa possui para 
lidar consigo. A fase de identificação da transição é a principal, pois se pode entender e explorar como o indivíduo considera a transição, analisando esta fase. Ao longo do processo, a transição deve ser considerada sobre quatro conjuntos de variáveis: a situação, o self, o apoio e as estratégias de coping. Sobre o self os autores salientam as características pessoais e sociodemográficas: gênero, idade, estado de saúde, classe social e recursos psicológicos como desenvolvimento do ego, autoeficácia, investimento e valores. As pessoas em sua pluralidade encaram a mesma transição de forma distinta e estes pontos abordados são de fundamental importância para entender tal fato.

A partir das referências apresentadas anteriormente pode-se entender a transição da universidade para o trabalho como um acontecimento de vida previsível (aos que estão no Ensino Superior) e que requer mudanças comportamentais e relacionais. Efetivamente, a transição da universidade para o trabalho representa uma transição desenvolvimental crítica do jovem adulto, uma vez que o esperado é que ao final de seu curso o graduando já esteja com um percurso e planos definidos, não apenas no plano profissional, mas também pessoal. No entanto, como refere Caires (2001), apesar de ser esperado uma resolução e um aumento dos níveis de competências contata-se que ao sair da graduação um número considerável não resolveu as múltiplas tarefas desenvolvimentistas que a fase impõe.

Menezes, Matos e Costa (1989) aludem que "ao concluir o curso e iniciar uma carreira, não significa apenas a possibilidade de independência econômica, mas também de investimento e exploração de temáticas existenciais tais como: identidade profissional, a separação da família de origem, o compromisso com relações de vinculação mais duradoras, o investimento na produtividade, a construção de um projeto de vida e o estabelecimento de si próprio como adulto".

A proximidade de "abandonar" o Ensino Superior traz à margem uma série de dúvidas vocacionais que vão desde questionamentos sobre a capacidade de conseguir um emprego até a competência para exercer as funções de forma eficaz e satisfatória. A transição da universidade para o trabalho se inscreve em um amplo espectro que traz ao jovem adulto desafios e necessidades.

\subsection{O universitário brasileiro e a transição.}

As inúmeras e velozes transformações que vem ocorrendo no contexto organizacional e do trabalho exigem dos profissionais habilidades de adaptação e uso de estratégias eficientes 
para o enfrentamento das novas demandas do mundo do trabalho e da civilização. Segundo Silva (2006), o mercado de trabalho no modo de produção capitalista e em sociedades neoliberais, como no caso do Brasil, vivenciam cada vez mais a precariedade e flexibilização das relações de trabalho marcado pelas inúmeras transições ocupacionais e desemprego estrutural, para parcelas significativas da sociedade, ainda que as estatísticas mais recentes (CENSO, 2010) apontem para o pleno emprego no Brasil, sobretudo para as pessoas qualificadas. Nesse ambiente dinâmico e competitivo, onde o conhecimento e a qualificação profissional são imperativos, os indivíduos buscam a educação como alternativa para aumentarem suas chances de adaptação e sucesso profissional (BOWERS; DICKEMAN; FUQUA, 2001).

Nesse sentido, a partir de 2004, observa-se, no Brasil, a criação de políticas públicas que facilitam o acesso e a permanência da população, no Ensino Superior público (REUNI ${ }^{1}$ ) e particular (PROUNI ${ }^{2}$ ). O Censo da Educação Superior de 2008 (INEP, 2009) aponta para um crescimento significativo de 37\% no número de instituições de Ensino Superior no país entre 2002 e 2008. São mais de 24.000 cursos de graduação presenciais e mais de um milhão e meio de ingressos. O número total de vagas ofertadas por processos seletivos na graduação presencial em 2008 foi de 2.985.137 em todo o Brasil, correspondendo a um incremento de 161.195 (5,7\%) em relação ao ano anterior, sendo as instituições federais responsáveis pelo maior aumento no número de vagas oferecidas, registrando a abertura de 14.462 novas vagas em relação a 2007. O Censo da Educação Superior de 2008 informa que cerca de 870.000 pessoas concluíram a graduação em 2008. Se por um lado têm-se dados animadores sobre o acesso ao ensino superior no país, por outro lado, em pesquisa realizada pelo Observatório Universitário (GÓIS, 2006; NUNES, 2006), constatou-se que 53\% dos universitários que se formam no Brasil atuam em áreas diferentes da sua formação.

Analisando os dados de acesso ao Ensino Superior brasileiro e a inserção profissional dos graduados nas suas áreas de formação, conclui-se que apenas o diploma de curso superior não torna mais fácil a adaptação do recém-formado ao mercado de trabalho nem garante o estabelecimento e sucesso na carreira escolhida. Nesse sentido, percebe-se a existência de algumas dificuldades encontradas pelos universitários brasileiros na transição do sistema educacional para o sistema produtivo.

\footnotetext{
${ }^{1}$ Planos de Reestruturação e Expansão das Universidades Federais (REUNI) tem como principal objetivo ampliar o acesso e a permanência na Educação Superior. O Reuni foi instituído pelo Decreto $n^{\circ} 6.096$, de 24 de abril de 2007, e é uma das ações que integram o Plano de Desenvolvimento da Educação. (www.reuni.mec.gov.br).

${ }^{2}$ Programa Universidade para Todos (PROUNI) foi criado em 2004, pela Lei n ${ }^{\circ} 11.096 / 2005$, e tem como finalidade a concessão de bolsas de estudos integrais e parciais a estudantes de cursos de graduação e de cursos sequenciais de formação específica, em instituições privadas de Educação Superior (www.portal.mec.gov.br).
} 
Severino (2009), em seu artigo intitulado: "Expansão do ensino superior: contextos, desafios e possibilidades", traz um panorama dos números do Ensino Superior no país segundo Censo (2007): o Brasil apresenta na atualidade 2.281 IES das quais 183 são universidades, 120 são Centros Universitários e 1.978 faculdades isoladas. Esses números representam uma expansão em relação a 2006 de apenas 0,5\%. Ainda salienta que o país conta com 4.880.381 matrículas das quais 2.644.187 estão feitas nas universidades, 680.938 nos Centros Universitários e 1.555.256 nas Faculdades Isoladas. Das 183 universidades, 96 são públicas (52,5\%) e 87, privadas (47,5\%); já dos 120 Centros Universitários 116 são privados $(96,7 \%)$ contra quatro públicos; e das 1978 faculdades, 1829 são privadas $(92,5 \%)$ e 149 públicas (7,5\%). No cômputo geral, das 2.281 IES, $89 \%$ são instituições privadas e apenas $11 \%$ públicas, sendo $4,6 \%$ federais, 3,6\% estaduais e 2,7\% municipais. Quanto à evasão, o referido autor aponta para os altos índices de evasão das universidades brasileiras. Em 2007 esta taxa foi de 41,9\%, sendo 27,4\% no ensino público federal, 36,2\% no ensino público estadual, $37,6 \%$ no ensino público municipal e $44,6 \%$ no ensino privado (SEVERINO, 2009).

No Brasil apenas 6,37\% da população com 23 anos ou mais de idade tem educação formal de nível superior. A situação do Brasil em relação aos países membros da Organização para a Cooperação e o Desenvolvimento Econômico (OCDE) da União Europeia é muito inferior em relação à média dos países membros que é de $22 \%$ da população adulta com ensino superior completo.

Os dez cursos com maior representação de graduados são todos de profíssões regulamentadas e agregam 67,4\% do total (Direito, Administração, Pedagogia, Engenharias, Letras, Ciências Contábeis e Atuariais, Medicina, Ciências Econômicas, Comunicação Social e Odontologia). Somando-se a esses os graduados nos cursos de Psicologia, Biologia e Enfermagem, que também são de profissões regulamentadas, ou seja, $73 \%$ do total do estoque de mão de obra com mais de 23 anos de idade e formação superior (NUNES e CARVALHO, 2006).

No Brasil são poucas as pesquisas que investigam o fenômeno: transição da universidade para o mercado de trabalho e o status do jovem sobre esta fase. Porém para este estudo buscou-se levantar algumas pesquisas sinalizadoras, da tomada de decisão e sua implicação para os estudantes na realidade das universidades brasileiras.

Bastos (1997), ao realizar uma investigação com 56 alunos concluintes do curso de Psicologia, identificou que a "crise" de final de curso pela qual passa o concluinte caracterizase por uma indefinição de interesses, uma visão obscura de suas dificuldades, quase uma 
ausência de planos para superá-las e um sentimento negativo em relação a este estado. Para a autora, uma forma de superar este momento seria investindo nos estágios, principalmente os estágios supervisionados, que possibilitariam um contato maior com o mundo do trabalho e também uma forma de superação do dilema teoria e prática (BASTOS, 1997).

Neiva (1996) identificou que os estudantes universitários que estimavam menos tempo para iniciar o exercício profissional mostravam-se mais decididos quanto ao projeto pósuniversitário e a futura atividade profissional, ou seja, aqueles que previam menos tempo para conseguir a inserção no mundo do trabalho também demonstravam maior decisão em sua trajetória profissional. Dados coletados posteriormente, em 1997, mostraram que esses mesmos alunos tiveram uma inserção profisssional quase imediata. Esses estudos apontam para a identificação de uma variável: a decisão de carreira como um elemento fundamental no entendimento dos processos psicológicos que interferem no processo de transição para o mercado de trabalho (NEIVA, 1996).

Coelho (2000) desenvolveu uma pesquisa com 249 formandos dos cursos de Administração, Ciências Contábeis, Direito, Engenharia, Psicologia, Comunicação Social e Processamento de Dados sobre a percepção em relação às tendências nas exigências profissionais e as atuais condições de mercado. A autora identificou, por meio da análise de um questionário, que os jovens percebem as tendências das exigências profissionais consoantes às próprias habilidades e competências. Os participantes apontaram para a existência de uma discrepância entre o que o jovem percebe e a sua ação para enfrentar os desafios da inserção no mercado. Para que isso possa ser superado indicaram a necessidade de maior flexibilidade disciplinar, maior envolvimento e compromisso com o curso. Assim, a autora concluiu que o grupo de formandos estudado não está se preparando e não é preparado para enfrentar as mudanças decorrentes do término do Ensino Superior e ressalta que a principal condição de adaptabilidade às exigências de trabalho no mundo atual é a próatividade nos diferentes papéis da vida do indivíduo. Sendo este um tema que deverá ser de alguma forma introduzido nas discussões sobre os currículos e inserido na realidade educacional brasileira (COELHO, 2000).

Por sua vez, Callegari (2001) desenvolveu um estudo sobre os aspectos facilitadores e as dificuldades da inserção profissional de 110 universitários egressos de uma universidade particular do Rio Grande do Sul. Por meio da análise de regressão múltipla dos dados coletados via questionário, foi possível identificar que a inserção profissional em grande parte está relacionada aos determinantes pessoais dos egressos, isto é, às atitudes e características frente ao trabalho, tais como: valorização do próprio potencial, disponibilidade e interesse na 
busca de emprego, autoeficácia percebida, busca por status profissional, bem como a iniciativa, persistência e não acomodação ao mercado de trabalho (CALEGARI, 2001).

Enge (2004), ao realizar uma pesquisa sobre o período de transição entre o Ensino Superior e o ingresso no mercado de trabalho de um grupo de 152 egressos do curso de licenciatura da Universidade Estadual de São Paulo (USP), formados entre 1994 e 1995, identificou que, ao contrário do que se poderia supor, a opção por um curso superior não corresponde a uma escolha profissional pontual, mas faz parte de um processo histórico e social que o sujeito está envolvido. Isto porque é resultado de um processo contínuo e complexo no qual estão relacionados diversos fatores como, por exemplo: afinidade com determinada área, a influência do meio social e limitações de ordem financeira. Além disso, o valor social do diploma é muito grande, sobretudo quando se trata de uma universidade pública: este é visto como uma espécie de salvaguarda contra o desemprego. Para a autora, o mercado de trabalho assume um importante papel na construção das carreiras profissionais, sendo as oportunidades encontradas determinantes das trajetórias individuais dos egressos. Isto evidencia que a opção de carreira feita ao término do Ensino Superior não se circunscreve somente com as experiências que o estudante teve ao longo de seu período de formação, mas tem relação com o seu contexto social e a sua própria percepção de competência. O que se torna evidente na análise das produções relacionadas anteriormente é que o sentimento de insegurança e incerteza marca o momento do término dos estudos do Ensino Superior (ENGE, 2004).

Considerando o exposto anteriormente, pode-se concluir que essa pesquisa se insere no conjunto de estudos desenvolvidos na linha de pesquisa "Orientação profissional, educação e desenvolvimento de carreira: diagnóstico e intervenção", que focaliza a Avaliação em Orientação Profissional (MELO-SILVA, 2000; MELO-SILVA, JACQUEMIN, 2001; MELOSILVA, ALMEIDA, LOOSLI, FRAGA, 2004; MELO-SILVA, 2005). A avaliação da intervenção psicológica em orientação profissional é realizada sob três perspectivas: (1) avaliação da pessoa; (2) avaliação de problemas e problemáticas; e (3) avaliação de processos e resultados de procedimentos de intervenção. Este estudo visa contribuir para a produção do conhecimento relativa à avaliação de problemas e problemáticas. Nesse caso, o problema de investigação focaliza a tomada de decisão para a carreira, através de um instrumento de medida. 
3. OBJETIVO 



\section{1. Geral}

O presente estudo tem como objetivo geral, analisar as qualidades psicométricas em termos de confiabilidade e validade dos resultados, e analisar os resultados em termos de validade por referência de critério da versão brasileira do Questionário de Dificuldades de Tomada de Decisão de Carreira (GATI; SAKA, 2001), com alunos finalistas do Ensino Superior, de diferentes cursos de três universidades brasileiras. 
4. MÉTODO 



\subsection{Participantes}

Considerando os objetivos deste estudo foram organizadas duas amostras de participantes. A primeira delas (amostra I) para a validação semântica do instrumento utilizado no estudo. A segunda (amostra II) para a validação estatística (fatorial) e análise da Tomada de Decisão para a Carreira, perfazendo um total de 535 universitários. Após a exclusão de questionários incompletos, a amostra foi totalizada em 511 participantes.

Para a validação semântica o instrumento foi aplicado inicialmente em uma amostra experimental de 11 estudantes universitários com o propósito de analisar o conteúdo dos itens e a compreensão. O instrumento foi aplicado individualmente em universitários dos últimos anos, com o intuito de fazer uma discussão dirigida sobre a compreensão dos itens e das respostas.

$\mathrm{Na}$ validação estatística (fatorial) participaram 500 estudantes universitários que, de acordo com as indicações de Tabachnick e Fidell (1989), é um tamanho adequado para a realização da análise fatorial.

Para a caracterização da amostra foi feito um registro de dados pessoais, profissionais e educacionais. Compreendendo dados tais como: sexo, idade, curso, série escolar, tipo de universidade, pretensão de inserção na área do curso de graduação, classe socioeconômica, participação em estágios na graduação, nível de confiança na escolha do curso, autoavaliação sobre dificuldade de tomada de decisão para a carreira, pergunta esta utilizada como critério para a Validade Convergente.

Os 500 estudantes universitários, utilizados na amostra II, são provenientes de diferentes cursos de graduação. A Tabela 3 mostra a distribuição dos participantes do presente estudo em função dos cursos de graduação (frequência e porcentagem). 
Tabela 3 - Distribuição da amostra $(n=500)$ em função do curso de graduação.

\begin{tabular}{lcc}
\hline Curso & $\mathrm{N}$ & $\%$ \\
\hline Administração & 91 & 18,2 \\
Direito & 75 & 15,0 \\
Psicologia & 68 & 13,6 \\
Odontologia & 65 & 13,0 \\
Engenharia Civil & 25 & 5,0 \\
Ciências Contábeis & 25 & 5,0 \\
Pedagogia & 24 & 4,8 \\
Biologia & 24 & 4,8 \\
Física médica & 18 & 3,6 \\
Enfermagem Licenciatura & 16 & 3,2 \\
Química Licenciatura & 15 & 3,0 \\
Ciências da Computação & 15 & 3,0 \\
Engenharia Elétrica & 14 & 2,8 \\
Química Bacharelado & 7 & 1,4 \\
Enfermagem Bacharelado & 6 & 1,2 \\
Sistema de Informação & 5 & 1,0 \\
Economia Empresarial & 3 & 0,6 \\
Matemática & 2 & 0,4 \\
Ciência da Informação & 1 & 0,2 \\
Informática Biomédica & 1 & 0,2 \\
\hline & &
\end{tabular}

A amostra é composta por estudantes entre 22 e 25 anos de idade. A faixa etária da amostra apresentou média de 23,6 anos, apresentando desvio padrão de 2,65, sendo a idade mínima do participante de 18 anos e a máxima de 33 anos, correspondendo à faixa etária predominante nas universidades brasileira. (Censo da Educação do Ensino Superior, 2008). A amostra é composta predominante por estudantes solteiros (77\%), do sexo masculino (45\%) e feminino (55\%). Ainda que se tenha buscado colaboradores (estudantes voluntários) de carreiras das três áreas básicas do conhecimento, a colaboração maior para este estudo foi de estudantes provenientes de cursos de Humanas como mostra a Tabela 4. 
Tabela 4 - Distribuição da amostra $(n=500)$ por área de curso.

\begin{tabular}{lcc}
\hline Curso & $\mathrm{n}$ & $\%$ \\
\hline Humanas & 261 & 52,2 \\
Biológicas & 111 & 22,2 \\
Exatas & 128 & 25,6 \\
\hline
\end{tabular}

A maior parte da amostra é caracterizada por universitários provenientes de cursos de graduação de universidades públicas, como aponta a Tabela 5.

Tabela 5 - Distribuição da amostra $(n=500)$ por faculdade.

\begin{tabular}{lcc}
\hline Faculdade & $\mathrm{N}$ & $\%$ \\
\hline Pública & 288 & 57,6 \\
Privada & 212 & 42,4 \\
\hline
\end{tabular}

O nível sócio-econômico da amostra foi obtido através de questionário da ABEP (Associação Brasileira de Empresa de Pesquisa) (Anexo A). Este questionário divide as classes sociais em sete categorias, a partir do poder de consumo.

Tabela 6 - Distribuição da amostra $(n=500)$ por classe social segundo os critérios da ABEP.

\begin{tabular}{ccc}
\hline Classe social & $\mathrm{N}$ & $\%$ \\
\hline A1 & 38 & 7,6 \\
A2 & 137 & 27,4 \\
B1 & 135 & 27 \\
B2 & 117 & 23,4 \\
C1 & 47 & 9,4 \\
C2 & 20 & 4 \\
D & 6 & 1,2 \\
\hline
\end{tabular}

Do pondo de vista socioeconômico, os alunos da amostra encontram-se predominantemente nos níveis médio (B1 e B2) e alto (A2), totalizando 77,5\% da amostra, como mostra a Tabela 6 , com mais de $20 \%$ em cada estrato. 
Tabela 7 - Distribuição da amostra $(n=500)$ por escolaridade do chefe de família.

\begin{tabular}{lcc}
\hline \multicolumn{1}{c}{ Escolaridade do chefe de família } & $\mathrm{N}$ & $\%$ \\
\hline Analfabeto / Até $3^{\mathrm{a}}$ Série Fundamental & 23 & 4,6 \\
Até $4^{\mathrm{a}}$ Série Fundamental & 60 & 12 \\
Fundamental completo & 51 & 10,2 \\
Médio completo & 145 & 29 \\
Superior completo & 221 & 44,2 \\
\hline
\end{tabular}

No que se refere à formação educacional do chefe de família, predomina o Ensino Superior (44,2\%), seguido do Ensino Médio (29\%), como pode ser observado na Tabela 7.

Esse estudo, portanto, circunscreve-se em um dado perfil populacional, ou seja, das camadas socioeconomicamente favorecidas, cujos dados devem ser analisados em relação à população universitária brasileira (Censo da Educação do Ensino Superior, 2008).

\subsection{Instrumentos}

Para atingir os objetivos do primeiro estudo optou-se pela utilização de um instrumento em língua inglesa de origem hebraica, que avaliam as dificuldades de tomada de decisão para a carreira (CDDQ- Career-Decision-making Difficulties Questionnaire ${ }^{3}$ ). Este instrumento foi avaliado através de exames estatísticos para validade fatorial e confiabilidade visando a sua utilização no Brasil para universitários.

Além do questionário, foram utilizados dois programas estatísticos Software Statistical Package for the Social Sciences (SPSS), versão 16.0 e SAS versão 9.2, para realização das análises estatísticas pretendidas.

\subsubsection{Questionário de Dificuldade de Tomada de Decisão (CDDQ- R)}

O Questionário de Dificuldade de Tomada de Decisão para a Carreira (Career Decision-Making Difficulties Questionnaire) (GATI, KRAUSZ e OSIPOW, 1996), é um

\footnotetext{
${ }^{3}$ A utilização do CDDQ em pesquisas ou com finalidade diagnóstica deve ser realizada mediante aprovação dos autores Gati ou Osipow, através dos contatos, e-mail: itamr.gati@huji.ac.il ou telefone(+972) 2.5882084.

Observar anexo D.
} 
instrumento que visa avaliar o construto da indecisão na carreira. O CCDQ é uma esquematização em forma de questionários de uma taxionomia sobre as dificuldades de tomada de decisão na carreira, desenvolvida pelos autores do instrumento (GATI; OSIPOW, 2001). Apresenta-se como um instrumento diferenciado, pois se encontra baseado em premissas teóricas gerais sobre o comportamento de decisão, não é somente um resultado obtido exclusivamente de forma empírica.

Neste estudo foi utilizado o Questionário de Dificuldades de Tomada de Decisão de Carreira (CDDQ 34, GATI ; SAKA, 2001), com tradução para o português. Trata-se de uma versão abreviada com 34 itens do questionário CDDQ. O questionário engloba todos os problemas associados a dificuldades de tomada de decisão de carreira, apresentando três categorias principais de dificuldades: a Falta de Prontidão, a Falta de Informação e a Informação Inconsistente. Encontram-se divididas em dez categorias específicas de dificuldades. Assim, a Falta de Prontidão inclui a Falta de Motivação, a Indecisão Generalizada e as Crenças Disfuncionais. As categorias principais, Falta de Informação e Informação Inconsistente englobam categorias de dificuldades que ocorrem durante o processo de tomar uma decisão de carreira. A categoria principal Falta de Informação inclui as subcategorias de Falta de Informação acerca do Processo de Tomada de Decisão, Falta de Informação acerca do Self, Falta de Informação acerca das Ocupações e Falta de Informação acerca das Fontes Adicionais de Informação. E, a categoria Informação Inconsistente, engloba as subescalas: Informação pouco Fidedigna, Conflitos Internos e Conflitos Externos.

A primeira parte do questionário é dedicada à informação sociodemográficas, incluindo-se a idade, sexo, curso, semestre, universidade, classe socioeconômica, realização de estágios e nível de confiança no curso escolhido. Ao final do questionário é solicitado aos participantes, também a sua autoavaliação referente ao seu processo de tomada de decisão, por meio da resposta à questão "Finalmente, como pontua, em termos gerais, o seu grau de dificuldade ao tomar decisões de carreira”. O questionário, em si, inclui um conjunto de 34 afirmações relacionadas com as dificuldades de tomada de decisão, tal como definidas por Gati e cols. $(1996,2001)$. Nesta parte, a resposta aos itens é realizada, usando uma escala de likert, com nove pontos, em que 1 significa "Não me descreve" e 9 significa "Descreve-me bem".

O CDDQ34 permite-nos obter 14 resultados diferentes, um resultado para cada uma das dez subescalas de dificuldades (calculo da média aritmética das respostas aos itens que as compõem), um resultado para as três categorias principais (cálculo da média aritmética das subescalas que integram a categoria) e ainda, um resultado para o total do CDDQ34. 


\subsection{Procedimentos}

\subsubsection{Cuidados éticos}

Inicialmente, este projeto foi submetido à apreciação do Comitê de Ética em Pesquisa com Seres Humanos da Faculdade de Filosofia, Ciências e Letras de Ribeirão Preto - USP, iniciando-se a coleta de dados somente após sua aprovação. Ressalta-se que os cuidados relativos à utilização de instrumentos de avaliação psicológica e de documentação dos respectivos protocolos foram devidamente assegurados, conforme princípios éticos e legais vigentes na Comissão Nacional de Ética em Pesquisa (CONEP) do Conselho Nacional de Saúde do Ministério da Saúde e no Conselho Federal de Psicologia (CFP).

Os participantes foram informados pela pesquisadora sobre os objetivos, por meio de linguagem compreensível, e que possuem liberdade para participar ou não da pesquisa e assim como a possibilidade de desistir a qualquer momento do estudo, além de informações complementares sobre a confidencialidade dos dados pessoais e esclarecimento a partir das dúvidas levantadas (COZBY, 2003). Em seguida foi entregue o Termo de Consentimento Livre e Esclarecido (ANEXO B). Esse documento informa sobre a pesquisa e as formalidades no que se refere ao sigilo dos dados pessoais dos participantes.

O presente projeto de pesquisa foi submetido ao Comitê de Ética em Pesquisa da Faculdade de Filosofia, Ciências e Letras de Ribeirão Preto da Universidade de São Paulo, conforme Resolução 196/96 do Conselho Nacional de Saúde, disponível em www.conselho.saude.gov/br/docs/Resolucoes/Reso196.doc, e Resolução 16/00 do Conselho Federal de Psicologia (www.pol.org.br/legislacao/doc/resolucao2000_016.doc) sob $\mathrm{n}^{\circ}$ 466/2009 (ANEXO C).

Após ciência e concordância dos entrevistados, o Termo de Consentimento Livre e Esclarecido foi assinado em duas vias, uma para o participante e outra para a pesquisadora. Os resultados do estudo serão apresentados junto à comunidade participante do estudo e exemplares da forma final do estudo serão entregues nas universidades de origem dos colaboradores. 


\subsubsection{Coleta de dados}

Os procedimentos de coleta de dados foram divididos em duas etapas: 1) validação semântica; 2) validação estatística;

Pasquali (2004) salienta que quando o objetivo do trabalho é validar instrumentos de medida é necessário primeiro realizar a validação semântica, ou seja, testar a qualidade dos itens do instrumento e testá-los em uma amostra experimental. Se a validação semântica estiver adequada, pode-se iniciar o processo de validação estatística.

Os dados foram recolhidos por psicólogos e estagiários de Psicologia, com a autorização prévia da direção dos estabelecimentos de Ensino Superior. A coleta de dados foi realizada com estudantes universitários que foram contatados através dos coordenadores e professores de universidades públicas e particulares de três cidades sendo uma de pequeno porte (no Estado de Mato Grosso do Sul, MS), uma média (em Minas Gerais, MG) e outra maior (em São Paulo, SP). Após o primeiro, contato foi feito o agendamento de data e horário mais convenientes de modo a não causar prejuízos às atividades acadêmicas dos estudantes. No dia marcado, a pesquisadora informou aos alunos sobre os objetivos da pesquisa, as características do instrumento, o tempo de aplicação, respeitando-se todos os procedimentos éticos envolvidos, deixando-os livres para decidir sobre participar ou não da pesquisa. $\mathrm{O}$ instrumento foi aplicado em aproximadamente 30 minutos durante o período em que os alunos estavam em sala de aula

\subsubsection{Análise dos Resultados}

Os dados coletados foram transcritos para uma planilha do programa SPSS for Windows, versão 16.0, onde foi criada uma base de dados. Em seguida, foram feitas várias análises estatísticas para as escalas do instrumento de medida utilizado, bem como para o seu conjunto. Para cada etapa do trabalho foram utilizados diferentes procedimentos de análise dos dados.

Para se cumprir os objetivos deste trabalho os resultados foram analisados a partir dos referencias considerados a seguir sobre a validade de um teste psicológico. Pasquali (2001), define a validade de um teste psicológico como a capacidade deste instrumento avaliar, de fato, o que supostamente anuncia medir. 
Fachel e Camey (2000) apontam existiriam três tipos de validade: validade de conteúdo, validade de critério e validade de construto (ou conceito). A validade de conteúdo refere-se ao exame sistemático do conteúdo do instrumento de avaliação psicológica, determinando se seus itens cobririam uma amostra representativa do comportamento a ser medido e se a escolha dos itens está apropriada e relevante. Pode ser subdividida em dois tipos: validade de conteúdo e validade aparente. Essa validade pode ser avaliada por meio da concordância do julgamento de juízes, peritos na área do traço medido, que avaliam a representatividade dos itens em relação aos conceitos e à relevância dos objetivos a medir (validade de conteúdo propriamente dita) ou por meio da avaliação da linguagem, da forma com que o conteúdo do instrumento está sendo apresentado (validade aparente).

A validade de critério, por sua vez, pode ser subdividida em validade concorrente e validade preditiva. Diz respeito ao quanto o instrumento de avaliação é capaz de predizer, temporalmente, uma determinada variável chamada de critério (FACHEL; CAMEY, 2000). O critério poderia ser obtido por resultados advindos de outros instrumentos ou por fatores externos aos instrumentos, como desempenho acadêmico e autojulgamentos, segundo Pasquali (2001).

A validade de construto refere-se ao grau pelo qual um instrumento de avaliação mede o componente teórico ou traço para o qual ele foi designado, ou construído, para medir. No entanto, como o construto é uma variável latente não-observável, ele não pode ser diretamente mensurado. Para se averiguar esta validade, Anastasi (1988), afirma que a validade relacionada ao construto requer a acumulação gradual de informação utilizando-se várias fontes, dividas em três tipos de validade: validade convergente, validade discriminante e validade fatorial. A validade convergente relaciona-se à medida da correlação existente entre o teste novo e um instrumento já considerado como válido pela comunidade científica da área (que avalie o mesmo construto teórico). Quanto maior a correlação entre eles, maior a possibilidade do novo instrumento alcançar estimativas sobre este construto em foco. Já a validade discriminante focaliza o quanto a medida em questão difere, significativamente, de construtos distintos, observados por outras técnicas avaliativas também já existentes e reconhecidas em seus propósitos. Por fim, a validade fatorial recorre a análises estatísticas multivariadas para identificar traços psicológicos (fatores latentes) nos itens de um instrumento de avaliação psicológica. Neste trabalho serão realizadas análises para aferir a validade fatorial e por referência de critério.

A análise fatorial, comumente utilizada para este tipo de validade, afirma que um número menor de traços latentes é o bastante para explicar um número maior de itens, ou seja, 
ela explicita o que o instrumento em questão está medindo, isto é, os fatores, bem como clarifica quais itens compõem cada fator (PASQUALI, 2009, 2010).

Para este estudo foram realizadas: (a) a validação de conteúdo denominada semântica (Pasquali, 2004), (b) a validação de construto representada pela validade fatorial e (c) a validade por referência de critério (ALMEIDA; FREIRE,1997).

Para a validação de conteúdo ou semântica foi realizada primeiramente a tradução do inglês para o português por um perito com fluência na língua inglesa. Logo em seguida um grupo de juízes (duas psicólogas) discutiu o conteúdo dos itens traduzidos. Após tal análise, foi realizada a tradução inversa (back translation) para a confirmação da correspondência semântica com a versão original. Um ensaio experimental foi feito para a confirmação da adequação dos itens do instrumento para a realidade brasileira, através de um estudo dirigido em grupo e individualmente.

De acordo com indicações de Pasquali (2004), para a validação estatística foram avaliados os parâmetros da dimensionalidade, confiabilidade e validade. A dimensionalidade é um aspecto central na análise dos itens e foi avaliada através da análise fatorial, que consiste em verificar se uma série de itens pode ser reduzida idealmente a uma única dimensão ou variável, que é chamada de fator, com a qual todos os itens estão relacionados. A confiabilidade de um instrumento indica que ele é capaz de medir, com a menor margem de erro possível, o aspecto que ele se propõe a medir. Quanto mais próximo de 1, menos erro o teste comete ao ser utilizado. Este aspecto foi avaliado através do coeficiente de consistência interna ( $\alpha$ de Cronbach e correlação item-total).

Para o estudo da consistência interna da escala foi usado o índice alfa de Cronbach (CRONBACH, 1951). Este índice tem por objetivo estimar a confiabilidade de um questionário aplicado em uma pesquisa. $\mathrm{O}$ alfa mede a correlação entre respostas em um questionário através da análise do perfil das respostas dadas pelos respondentes. Trata-se de uma correlação média entre perguntas. Dado que todos os itens de um questionário utilizam a mesma escala de medição, o coeficiente $\alpha$ é calculado a partir da variância dos itens individuais e da variância da soma dos itens de cada avaliador (HORA; MONTEIRO; ARICA, 2010).

Garson (2005), Pestana e Gageiro (2003), Nunnally (1978) e Taylor e colaboradores (2003) recomendam que a adequação e a satisfatoriedade do modelo alfa sejam testadas usando-se os seguintes critérios: índices alfa superiores a 0,80 são considerados desejáveis; índices superiores a 0,70 são considerados recomendados; índices superiores a 0,60 devem ser aceitos apenas para uso em pesquisa (desaconselhável o uso clínico). Sendo assim, qualquer 
resultado superior a 0,60 pode ser interpretado como uma consistência interna satisfatória, no enquadramento.

Para a validação fatorial foi realizada a análise da matriz de covariância em termos de fatorabilidade do número de fatores, primeiro foi feita a análise do tamanho das correlações, sendo considerada uma correlação importante quando o valor obtido estava acima de 0,30 , positivo ou negativo. Analisou-se a correlação e esta ultrapassou 50\% dos casos. Desta forma, pode-se concluir que a matriz poderá ser fatorizável; em um segundo momento foi realizado o Teste de adequação da amostra de Kaiser-Meyer-Olkin (KMO).

De acordo com Tabachnick e Fidell (1989), quando o objetivo da análise estatística é confirmar a estrutura ou teoria, é aconselhada a utilização da análise fatorial dos eixos principais (PAF) ao invés da análise dos componentes principais (PC). Desta forma, foram feitas estruturas fatoriais, por meio de análises fatoriais e utilizando o método de fatoração dos eixos principais (Principal Axis Factoring - PAF). Foi utilizado o método de rotação oblíqua (direct oblimin), já que esta permite que apareçam fatores ortogonais quando estes existem e, ao mesmo tempo, não força a dependência entre os fatores, ao passo que a rotação ortogonal só permite fatores independentes. Finalmente, após a extração dos fatores, para que os mesmos possam ser usados nas análises seguintes e futuras pesquisas, verificaram-se a estabilidade e interpretabilidade dos mesmos, bem como foram produzidos escores fatoriais. Para analisar a estabilidade, verificou-se o quanto os itens eram bons representantes do fator, pelo tamanho da carga fatorial: a correlação entre o item com o conjunto dos outros itens do fator (quanto mais próxima de 1 será melhor apresentado). Para analisar a interpretabilidade, identificou-se a questão possuía a ideia principal que provocava do agrupamento das variáveis, por meio da análise da literatura da área e a estrutura original do CDDQ-R (GATI; KRAUSZ; SAKA, 2000).

A fim de comprovar a estrutura fatorial do CDDQ, realizou-se também, uma Análise fatorial Confirmatória. Partindo-se da hipotética associação entre as três dimensões do construto avaliado para a amostra $(n=500)$, a adequação do modelo fatorial confirmatório foi testada usando os seis seguintes critérios: qui-quadrado, razão entre qui-quadrado e graus de liberdade, GFI (Goodness-of-fit Index), AGFI (Adjusted Goodness-of-Fit Index), a RMR (Root Mean Square Residual) e RMSEA (Root Mean Square Error of Approximation).

Critérios múltiplos foram utilizados uma vez que cada índice apresenta diferentes forças e fraquezas na avaliação da adequação do modelo fatorial confirmatório (TAYLOR; BAGBY; PARKER, 2003). São eles: o teste Qui-quadrado deve ser não significativo; a razão entre qui-quadrado e graus de liberdade deve ser menor que 5 (em valores nominais) ou, 
desejavelmente, menor que 2; o GFI deve apresentar um índice superior ou igual a 0,85 ; o AGFI deve apresentar um índice superior ou igual a 0,80; e, finalmente, o RMR deve apresentar um índice inferior ou igual a 0,10 e o RMSEA deve apresentar coeficiente inferior a 0,05 (ANDERSON; GERBING, 1984; BALBINOTTI, 2005; COLE, 1987; MARSH, BALLA; MCDONALD,1988; BROWNE; CUDECK, 1993).

Para a validade por referência a critério, foi utilizada uma pergunta final do questionário ("Finalmente, como você pontua seu grau de dificuldade de Tomada de Decisão para a carreira?”) será adotado como referência para a correlação. Vários critérios externos são frequentemente usados neste tipo de estudos Em função do tipo de prova ou dimensão avaliada, assim se poderão usar critérios mais centrados no desempenho ou mais voltados para aspectos da personalidade. Nestas duas situações, os critérios externos mais usados são: as classificações noutras situações de realização (notas escolares, níveis escolares atingidos, sucesso profissional, resultados noutras provas psicológicas similares) e as avaliações de personalidade (diagnóstico clínico, resultados da observação direta ou entrevistas, autoavaliações, relatos do sujeito por outros significativos e resultados noutras provas similares existentes) (ALMEIDA; FREIRE,1997). Para este estudo foi utilizado as avalições da personalidade através de uma autoavaliação no qual o participante avaliava seu grau de dificuldade de tomada de decisão, podendo classificá-la como Alta ou Baixa, para isto utilizou-se de uma escala de Likert de 9 pontos, na qual número 1 representava Baixa Dificuldade e o 9 Alta.

A validade por referência a critério foi, durante muito tempo, a única e a mais importante forma de validar um teste. Ela está intimamente ligada ao primeiro conceito a que a expressão "validade" aparece associado (grau em que o teste mede aquilo que pretende medir). Chamada validade externa, validade empírica, validade de critério ou validade por referência a critério(criterion)-related validity, esta é avaliada através do grau de relacionamento que é possível obter entre os resultados na prova (preditores) e a realização dos sujeitos em critérios externos, supostamente associados ou dependentes da dimensão psicológica que a prova avalia (GUION, 1974). Trata-se, pois, do tipo de validade que decorre da perspectiva psicométrica de observação (desempenhos e comportamentos em geral como reflexo de fatores internos a avaliar, testes como "bons" instrumentos de avaliação das dimensões internas, estabilidade das dimensões e possibilidade de boas inferências atuais e futuras a partir dos resultados nos testes para outras situações).

A validade por referência a um critério aparece, em alguns livros, subdividida em validade concomitante ou concorrente e validade preditiva ou de prognóstico. Falamos 
em validade concomitante ou concorrente quando se verifica uma simultaneidade no tempo entre a aplicação do teste e a obtenção das notas reportadas ao critério. Por validade preditiva ou de prognóstico entendemos os coeficientes obtidos através de estudos onde a informação relativa à prova e ao critério não são obtidas em simultâneo e, por norma, a informação no critério externo é posterior aos resultados no teste. Pode-se dizer que a validade por referência deste estudo é do tipo concomitante. Para se obter a validade por referência de critério foi realizado teste com o coeficiente de correlação de Pearson, também chamado de "coeficiente de correlação produto-momento" ou simplesmente de " $\rho$ de Pearson", que mede o grau da correlação (e a direção dessa correlação - se positiva ou negativa) entre duas variáveis de escala métrica (intervalar ou de razão).

Desta forma, com a análise dos resultados, buscou-se a validade do instrumento, ou seja, a capacidade do mesmo medir o que se propõe a medir. Este aspecto foi avaliado por meio da representação comportamental que utiliza novamente os resultados da análise fatorial, análise da consistência interna e análise das hipóteses (medidas teoricamente correlacionadas), que tem por fundamento avaliar o poder discriminativo do teste.

Ainda, foram realizadsa análises da normalidade, análise das frequências, médias, desvio-padrão, correlação entre a escala e comparações entre grupos para analisar o perfil dos universitários apresentadas nos apêndices A, B, C, D, E, F e G. 
5. RESULTADOS E DISCUSSÃO 

O Career Decision-Making Difficulties Questionnaire desenvolvido por Gati, Krausz e Osipow (1996), nos últimos dez anos, tem vindo a revelar-se um instrumento de medida promissor acerca da indecisão de carreira no cenário internacional, nomeadamente, dos fatores que contribuem para explicar as dificuldades que os indivíduos demonstram antes e durante o processo de tomada de decisão. Devido às suas características este questionário tem despertado interesse em diversos países (Portugal, Estados Unidos, Taiwan, Israel, Canadá, Itália), por se tratar de um instrumento de medida que assenta em bases teóricas sólidas desenvolvidas pelos modelos de tomada de decisão (GATI, 1986; MITCHELL; KRUMBOLTZ, 1984; PITZ; HARREN, 1980), sendo traduzido em diversas línguas (inglês, italiano, chinês, português- Portugal) (GATI, KRAUSZ, OSIPOW, 1996; GATI; SAKA, 2001; MAU, 2001).

O CDDQ (GATI; OSIPOW, 2001) no contexto brasileiro não apresenta estudos focados em validação para sua utilização com universitários. Alguns estudos o utilizaram como base para criação de novas escalas, porém sempre com adolescentes em transição do Ensino Médio para Universidade (PRIMI et al, 2000; MARTINS, 2009). No contexto internacional, especialmente em Portugal vários estudos estão sendo realizadas com as questões das dificuldades de tomada de decisão com os alunos de ensinos básicos e universitários portugueses (LOUREIRO; TAVEIRA, 2010; USSENE; TAVEIRA, 2010; SANTOS, 2009; SILVA; RAMOS, 2008), assim como pesquisadores norteamericanos (OSIPOW, 2001), chineses (MAU, 2001) e israelenses (GATI, 1996, 2001), como apresentado na Tabela 1.

Desta forma, os resultados obtidos na investigação do questionário descrito, bem como a discussão destes, são apresentados na seguinte ordem: resultados e discussão da análise semântica/conteúdo sobre o questionário de dificuldade de Tomada de Decisão para a Carreira (CDDQ) e sua aplicabilidade em uma amostra de estudantes universitários brasileiros de três universidades, especificamente dos estados de São Paulo, Minas Gerais e Mato Grosso do Sul, resultados e discussão das análises descritivas, a confiabilidade do instrumento, e as validades fatorial, análise confirmatória e validade por referência a critério.

\subsection{Validação Semântica e pertinência dos itens do CDDQ}

Após os procedimentos de tradução do questionário, foi realizada a análise semântica da versão brasileira, a qual segundo Pasquali (1997) consiste em "verificar se os itens dos 
questionários são inteligíveis para população meta.” (p. 96) e “...uma das maneiras mais eficazes para testar a compreensão dos itens é fazer entrevistas em grupos de três a quatro pessoas, em que se mostram os itens um a um e se pergunta às pessoas do grupo a que eles se referem. A quantidade de grupos a serem realizados depende da adequação dos itens a população alvo, sendo que itens testados, com dois grupos de sujeitos não apresentam problemas de compreensão não precisam mais ser ulteriormente checados" (Pasquali, 1997, p. 96).

Os resultados da aplicação experimental em dois grupos, num total de 11 universitários, evidenciaram que, de forma geral, os itens do instrumento estavam adequados e compreensíveis (nove respondentes não fizeram nenhuma consideração - disseram compreender todos os itens e instruções). Apenas três respondentes fizeram considerações sobre um item do questionário.

O item 30, que trata sobre características que incomodam na carreira almejada como fator impeditivo para tomar decisões, contém um exemplo com os seguintes dizeres: “por exemplo, eu estou interessado/a em medicina, mas não estou interessado em estudar tantos anos”. Como se trata de um questionário que foi aplicado em universitários em conclusão de um curso superior, visando à transição para o trabalho, o exemplo não foi considerado apropriado em relação ao objetivo do presente estudo. Foi sugerido por três respondentes que o exemplo fosse modificado, ou mesmo retirado, porque o item já era compreensível.

O questionário original (GATI; OSIPOW, 2001) foi criado para uso com estudantes no nível médio em transição para a universidade, neste sentido essa observação se torna pertinente, uma vez que deve ser adaptado para a transição entre universidade e mercado de trabalho. O CCDQ já foi utilizado com população universitária em dois estudos (MAU, 2001; ALBION; FORGATI, 2000). Porém, nenhum dos dois estudos faz referência sobre tais modificações na escrita dos itens.

Objetivando aprimorar a tradução foi solicitada a avaliação por duas juízas psicólogas, com atuação na área de orientação profissional, que realizaram a análise da tradução para avaliar a pertinência. Decidiu-se pela retirada apenas do exemplo do item 30.

Os itens do questionário, apesar de neste estudo não serem modificados, mantendo a tradução fidedigna da escala original, devem ser repensados. Como indicado por Fowlwer (1998 apud GUNTER, 2003) define que um bom item, que gerará respostas fidedignas e válidas devem seguir 5 características básicas: (1) pergunta precisa ser compreendida consistentemente; (2) a pergunta precisa ser comunicada consistentemente; (3) as expectativas quanto à resposta adequada precisam ser claras ao respondente; (4) os respondentes devem ter 
todas as informações necessárias; (5) os respondentes precisam estar dispostos a responder. O referido autor salienta que para manter tais atributos, cada pergunta deve ser específica, breve, clara, além de escrita em vocabulário apropriado. O que se pode perceber, no questionário em estudo, é que alguns itens originais do CDDQ não seguem tais recomendações.

Apesar dos resultados obtidos na validação semântica e ensaio experimental, que não apontaram necessidade de modificação dos itens, apenas retirada de exemplo (item 30), alguns itens mostram-se longos e apresentam duas ou mais ideias. Como exemplo pode citar o item 34: "Eu acho complicado tomar decisões de carreira porque as recomendações que vou recebendo, das pessoas que são importantes para mim, acerca da carreira que devo prosseguir, ou mesmo acerca das características das carreiras que devo considerar na minha decisão, são contraditórias.”. Assim como o item 33: “Eu acho complicado tomar decisões de carreira porque as pessoas que são importantes para mim (por exemplo, pais e amigos) não concordam com as opções que eu considero elou com as características da carreira que eu quero prosseguir.”.

Uma sequência de 11 itens apresentam os dizeres: "Eu acho complicado", o que torna a leitura monótona e repetitiva, o que segundo Gunter (2001) deve ser um dos passos a ser evitados na formulação dos itens. Porém, o instrumento original e os autores sinalizam para a manutenção da estrutura, permitindo apenas pequenas mudanças (ANEXO D). Desta forma, com futuras utilizações com o CDDQ sugere-se repensar a qualidade dos itens, aprimorando sua compreensão.

Assim sendo, na versão brasileira do CDDQ, para uso com universitários, manteve-se a tradução literal, apenas retirando-se o exemplo do item 30. O formato de aplicação dos demais itens continuou inalterado, contendo 34 afirmativas a serem respondidas em escala likert de 9 pontos. Recomenda-se o uso do exemplo quando se tratar de aplicação em estudantes do ensino médio que aspiram à carreira universitária. A partir dos resultados da Validação Semântica e Estudo Piloto foi reescrito o questionário para aplicação na amostra II e se achou pertinente, após a verificação do contexto universitário brasileiro e as significações de carreira que fosse realizada uma introdução.

O início do questionário apresenta os seguintes dizeres: "Este questionário tem como objetivo ajudar a identificar possíveis dificuldades e problemas relacionados com a tomada de decisão de carreira. Ao longo do questionário, utilizaremos o termo carreira para designar uma trajetória relacionada a: estudos, profissão, emprego, trabalho ou ocupação remunerada ou não. Ao responder ao questionário, procure pensar na decisão de carreira mais próxima ou que mais o/a preocupa.”. 
Esta introdução no questionário mostrou-se necessária, já que os países, citados acima, que utilizam amplamente o CDDQ, apresentam sistemas educacionais bastante distintos do sistema brasileiro. Além disso, eles desenvolvem diferentes programas de Orientação Profissional e de Carreira ao longo da vida escolar. Nos EUA, como exemplo, a Orientação para a Carreira no contexto escolar, denominada a Educação para a Carreira, é em geral integrada a serviços de orientação mais abrangentes, com ampla literatura sobre o assunto (BROWN, 2003; LAPAN, 2001; NCDA, 2008, 2009; NILES; BOWSLBEY, 2005).

Os Estados Unidos apresentam políticas públicas de Educação para a Carreira, com o objetivo de ampliar o acesso a todas as crianças e jovens em idade escolar e promover a integração entre Educação e Trabalho, objetivando facilitar a transição escola-trabalho. Em síntese, a "Educação para a Carreira é compreendida como um esforço do sistema educativo e de toda a comunidade para inserir nos conteúdos escolares atividades destinadas a ajudar os alunos a: (1) estabelecerem relações entre os conteúdos das disciplinas e as exigências de diferentes ocupações/ profissões; (2) fazerem do trabalho, como esforço contínuo, consciente, remunerado ou não, dirigido a produzir benefícios socialmente aceitáveis para si mesmo e/ou para os outros, uma parte significativa do seu estilo de vida e (3) adquirirem competênciaschave para um positivo desenvolvimento da carreira" (Munhoz, 2010, p.).

No Brasil, a forma de intervenção de carreira conhecida é a Orientação Vocacional ou Orientação Profissional, mais frequentemente desenvolvida em Serviços-escola de universidades, com predomínio em cursos de Psicologia, em consultórios psicológicos e em escolas de Ensino Médio privado. Com algumas exceções há programas de Gestão e Planejamento de Carreira em algumas universidades. Porém, serviços desta natureza não estão disponíveis a uma ampla parcela da população, pois inexiste política pública para a oferta de Orientação Profissional e de Carreira em escolas públicas ou privadas de ensino fundamental, médio e superior. Também não há serviços públicos para a realização de Orientação Profissional à população em geral. A legislação brasileira refere-se à Preparação para o Trabalho como um dos objetivos da Educação, sendo que durante o Ensino Fundamental e o Ensino Médio ela deve ser básica, ou seja, preparar crianças e jovens para prosseguir na carreira de forma a "vincular-se ao mundo do trabalho e à prática social" (BRASIL, LDB/1996).

O que se constata é que as intervenções em Orientação Vocacional/ Profissional ou de Orientação para a Carreira não têm acontecido nas escolas brasileiras de forma sistemática. Melo-Silva, Lassance e Soares (2004), apontam que em sua maioria, os programas de Orientação Vocacional/Profissional são destinados a jovens estudantes do ensino médio do sistema privado, em dúvida sobre a escolha da carreira universitária e realizados em sua maioria por psicólogos. 
Neste sentido o que se percebe no sistema educacional brasileiro é uma deficiência em preparar os alunos para se adaptarem às exigências do mundo globalizado. Nunes (2006) ressalta que desde o Ensino Médio os alunos precisam começar a optar por uma profissão futura, definindo simplesmente o curso de graduação a ser realizado. A partir daí começa, teoricamente o processo de tomada de decisão vocacional, fonte de grande angústia. Ao ingressarem nas instituições de ensino superior (IES), tendo vindo de um Ensino Médio marcado pela pressão dos vestibulares e da tomada de decisão, os estudantes pouco preparados para o mundo do trabalho buscam profissionalizar-se através da formação universitária. Para Nunes (2006), o há uma tendência em priorizar a formação técnica esquecendo-se da formação geral, mais ampla, que oferece mais recursos para que os universitários possam alcançar seus objetivos. “Amarrada a um currículo profissionalizante, a educação superior acaba se descuidando da preparação do estudante para um mundo complexo, no qual as profissões tornam-se obsoletas rapidamente e é freqüente a mudança de emprego e de ocupações ao longo da vida profissional" (p.8).

A partir destas constatações da realidade universitária brasileira, o presente instrumento buscou ampliar as discussões sobre a decisão e indecisão de carreira no contexto universitário, com o objetivo de serem analisadas suas características de confiabilidade e validade para a população universitária. Analisando sua pertinência para em futuras pesquisas, servindo de base para investigações e a avaliação de programas de Orientação de Carreira destinados ao público universitário.

\subsection{Análises descritivas das dificuldades de tomada de decisão para a carreira}

Nessa subseção serão apresentados os resultados das análises descritivas para os itens de resposta ao CDDQ34 (Tabela 8).

Pode-se verifica que as médias de respostas aos itens, encontradas na população de estudo $(\mathrm{n}=500)$, variaram entre 1,95 (item 2) e 6,67 (item 10), e os desvios-padrão variam entre os níveis 1,77 e 2,96. De forma geral, observa-se (Tabela 8) que a maioria dos participantes deram suas respostas entre as escalas 1 a 3. Os itens que mostraram menor distribuição nesta faixa foram os itens 8 e 10 (há maior concentração de repostas ente 7-9). O item 8 (“Ao exercer uma carreira que goste, estou também a resolver os meus problemas pessoais") apresentou média de 7,0 e Desvio padrão de 2,16. Já o item 10 ("Eu espero atingir todas as minhas aspirações através da carreira escolhida") apresentou média de 7,00 e Desvio Padrão de 2,5. Na escala original esta questão está dentro da escala que mede Crenças Disfuncionais. Um resultado elevado nesta área (Crenças Disfuncionais) reflete uma percepção distorcida do processo de tomada de decisão de carreira. 
Crenças e expectativas irracionais acerca de decisões de carreira, como por exemplo, a crença "Só se faz uma escolha de carreira uma vez na vida", ou "A escolha de uma carreira é um compromisso para a vida" ou ainda "Aquela profissão/ocupação poderá preencher todas as minhas aspirações, como pessoa", poderão afetar negativamente ou impedir o processo de tomada de decisão (GATI; KRAUSZ; SAKA, 2000).

Tabela 8 - Descrição da média, desvio-padrão e percentual de concentrações de respostas do $C D D Q$.

\begin{tabular}{|c|c|c|c|c|c|c|}
\hline \multirow{2}{*}{ Itens } & \multirow{2}{*}{ Casos Omissos } & \multirow{2}{*}{ Média } & \multirow{2}{*}{$\mathrm{DP}$} & \multicolumn{3}{|c|}{ Concentração de Resposta \% } \\
\hline & & & & $1-3$ & $4-6$ & $7-9$ \\
\hline 1 & 0 & 2,78 & 2,46 & 72,2 & 14,6 & 13,2 \\
\hline 2 & 0 & 1,95 & 1,84 & 86,4 & 7,8 & 5,8 \\
\hline 3 & 0 & 2,2 & 1,98 & 81 & 12,4 & 6,6 \\
\hline 4 & 0 & 3,87 & 2,63 & 53,2 & 25 & 21,8 \\
\hline 5 & 0 & 3,45 & 2,57 & 61,2 & 21,2 & 17,6 \\
\hline 6 & 0 & 4,6 & 2,96 & 44,8 & 20,6 & 34,6 \\
\hline 7 & 1 & 6,72 & 2,16 & 9,22 & 26,85 & 63,93 \\
\hline 8 & 1 & 6,18 & 2,5 & 17,03 & 27,46 & 55,51 \\
\hline 9 & 0 & 2,95 & 2,39 & 68,8 & 18,8 & 12,4 \\
\hline 10 & 2 & 6,67 & 2,49 & 14,66 & 21,28 & 64,06 \\
\hline 11 & 0 & 3,59 & 2,62 & 57,6 & 23,8 & 18,6 \\
\hline 12 & 0 & 2,28 & 1,88 & 80,4 & 14,4 & 5,2 \\
\hline 13 & 0 & 3,39 & 2,42 & 60 & 25,2 & 14,8 \\
\hline 14 & 0 & 3,22 & 2,33 & 62,6 & 24,4 & 13 \\
\hline 15 & 0 & 3,15 & 2,4 & 65 & 22 & 13 \\
\hline 16 & 0 & 3,08 & 2,38 & 65,4 & 21,6 & 13 \\
\hline 17 & 0 & 3,12 & 2,52 & 67 & 16,8 & 16,2 \\
\hline 18 & 0 & 2,6 & 2,2 & 76 & 13,8 & 10,2 \\
\hline 19 & 0 & 2,69 & 2,19 & 73,4 & 18,6 & 8 \\
\hline 20 & 0 & 2,27 & 1,97 & 81,6 & 11,8 & 6,6 \\
\hline 21 & 0 & 2,72 & 2,24 & 72,8 & 17,8 & 9,4 \\
\hline 22 & 1 & 2,81 & 2,23 & 70,34 & 20,24 & 9,42 \\
\hline 23 & 1 & 2,29 & 1,96 & 79,96 & 14,43 & 5,61 \\
\hline 24 & 0 & 2,29 & 1,97 & 80,6 & 12,4 & 7 \\
\hline 25 & 0 & 2,86 & 2,49 & 70 & 16,4 & 13,6 \\
\hline 26 & 1 & 2,54 & 2,25 & 75,95 & 13,83 & 10,22 \\
\hline 27 & 2 & 2,31 & 1,87 & 78,51 & 16,27 & 5,22 \\
\hline 28 & 3 & 4 & 2,83 & 53,72 & 19,92 & 26,36 \\
\hline 29 & 2 & 1,65 & 1,51 & 90,36 & 6,43 & 3,21 \\
\hline 30 & 2 & 2,38 & 2,25 & 79,72 & 9,84 & 10,44 \\
\hline 31 & 2 & 2,43 & 2,23 & 77,51 & 13,05 & 9,44 \\
\hline 32 & 2 & 2,09 & 1,82 & 84,14 & 10,64 & 5,22 \\
\hline 33 & 2 & 1,83 & 1,77 & 87,15 & 8,03 & 4,82 \\
\hline 34 & 2 & 2,03 & 1,88 & 84,34 & 10,24 & 5,42 \\
\hline
\end{tabular}


A Tabela 9, apresentada as médias e desvios-padrão de cada escala que compões os 3 fatores assim como do total do CDDQ. A média mais baixa corresponde à subescala Conflitos Externos $(M=1,93)$, enquanto a média mais alta é verificada na subescala Crenças Disfuncionais $(\mathrm{M}=4,98)$, pertencentes à categoria Falta de Prontidão. Em relação às escalas, a média mais alta é verificada na Prontidão $(\mathrm{M}=3,70)$ e a mais baixa é relativa à Informação Inconsistente $(\mathrm{M}=2,32)$. A média para o total do CDDQ é de 2,9. Sendo que as restantes médias encontram-se entre os valores 4-5 pontos. Os valores de dispersão são adequados face à amplitude das escalas (os desvios-padrão estão todos acima da unidade 1).

Tabela 9 - Descrição da Média e desvio padrão das subescalas e escalas principais do $C D D Q$.

\begin{tabular}{|c|c|c|c|c|c|c|}
\hline & \multicolumn{2}{|c|}{$\mathrm{N}$} & \multicolumn{2}{|r|}{ Desvio } & \multirow[b]{2}{*}{ Mínimo } & \multirow[b]{2}{*}{ Máximo } \\
\hline & Válido & Omissos & s Média & padrão & & \\
\hline FM & 500 & & 02,3162 & 1,52771 & 1,00 & 8,00 \\
\hline IG & 500 & & 03,9230 & 2,19561 & 1,00 & 9,00 \\
\hline $\mathrm{CD}$ & 500 & & 14,8743 & 1,65999 & 1,00 & 9,00 \\
\hline EPTD & 500 & & 03,2080 & 2,12039 & 1,00 & 9,00 \\
\hline S & 500 & & 02,8535 & 1,92675 & 1,00 & 9,00 \\
\hline $\mathrm{OC}$ & 500 & & 12,5800 & 1,81150 & 1,00 & 8,00 \\
\hline MIA & 500 & & 12,2849 & 1,75215 & 1,00 & 9,00 \\
\hline IPF & 500 & & 22,5496 & 1,70060 & 1,00 & 8,00 \\
\hline $\mathrm{CI}$ & 500 & & 32,4891 & 1,56138 & 1,00 & 8,00 \\
\hline $\mathrm{CE}$ & 500 & & 21,9320 & 1,64032 & 1,00 & 9,00 \\
\hline PRONTIDÃO & 500 & & 23,7060 & 1,16077 & 1,00 & 7,44 \\
\hline $\begin{array}{l}\text { FALTA DE } \\
\text { INFORMAÇÃO }\end{array}$ & 500 & & 22,7311 & 1,61172 & 1,00 & 8,06 \\
\hline $\begin{array}{l}\text { INFORMAÇÃO } \\
\text { INCONSISTENTE }\end{array}$ & 500 & & 32,3211 & 1,36646 & 1,00 & 7,22 \\
\hline TOTAL & 500 & & 92,9006 & 1,22157 & 1,00 & 7,03 \\
\hline
\end{tabular}

Neste sentido, esta escala mostrou-se com a maior média dentre todas as escalas, como pode ser observado na Tabela 9, que, ainda demonstra a média relativa a cada subescala: Escala Falta de motivação (FM), Indecisão Generalizada (IG), Crenças Disfuncionais (CD), 
Processo de Tomada de Decisão (EPTD), Self (S), Ocupações (O), Fontes de Informação Inconsitentes (MIA), Informaçõe Pouco Fidedignas (IFP), Conflitos Internos (CI) e Conflitos Externso (CE). Bem como a média das 3 fatores principais, segundo o modelo original (Prontidão, Falta de Informação acerca do Processo e Informação inconsistente).

\subsection{Validação fatorial}

\section{$\underline{\text { 5.3.1 Extração de fatores (PAF) }}$}

De acordo com Tabachnick e Fidell (1989), quando o objetivo da análise estatística é confirmar a estrutura ou teoria, é aconselhada a utilização da análise fatorial dos eixos principais (PAF) ao invés da análise dos componentes principais (PC), como apontam outros estudos com o CDDQ (MAU, 2001; GATI; KRAUSZ ; SAKA, 2000; ALBION; FOGARTY, 2002).

Para a Análise Fatorial dos Eixos Principais (PAF) optou-se pela rotação oblíqua devido às características da escala, que é composta por três escalas que, de acordo com os pressupostos teóricos utilizados em sua construção, devem apresentar correlação entre si, pois ambas avaliam dificuldade de Tomada de decisão na carreira.

Desta forma, as respostas dos 500 estudantes universitários aos 34 itens do questionário (sendo 2 de validade) foram submetidas às análises exploratórias, totalizando 500 casos. Foi identificado valor omisso - 1,7\% total da amostra - não sendo necessário estimar valores para substituir esses dados (TABACHNICK, 1989). Para iniciar a análise fatorial do construto, foi construída uma matriz de correlação.

Pasquali (2004) recomenda observar algumas características desejáveis na matriz para a verificação de sua fatorabilidade. A matriz deve apresentar mais de 10 casos para cada variável do instrumento. A atual matriz apresenta 14,7 casos por variável o que cumpre este critério. A normalidade e linearidade das variáveis segundo Pasquali (2004) não demonstram problema na análise fatorial. Porém, foi realizada análise de relações lineares entre as variáveis e observou-se que há relações lineares entre variáveis, todavia não foram identificados itens altamente correlacionados.

O tamanho das correlações e adequação da amostra foi analisado, com o intuito de observar a fatorabilidade da matriz de covariância, para confirmar a validade estatística e de construto da escala CDDQ, que é composta por 3 fatores. 
Iniciando as análises estatísticas dos 32 itens (pois 2 são itens de validade) da versão traduzida e adaptada para universitários brasileiros, realizou-se a análise exploratória e depois a análise fatorial (PAF) com rotação oblíqua.

O teste Kaiser- Meyer-Olkin (KMO) obteve-se um valor de 0,93, o que é considerado por Kaiser (1974) como excelente. Pasquali (2004), também, aponta este valor com para um excelente índice de adequação da amostra. $O$ teste de esfericidade de Bartlet (TABACHINICK, 1989) rejeitou a hipótese da matriz de correlações serem do tipo Identidade.A análise de scree plot dá maior ênfase foi para uma estrutura de 3 fatores a serem extraídos, conforme Figura 2.

Para extração inicial dos fatores foram realizados critérios convencionais de análise dos valores próprios e sua distribuição. A análise dos componentes principais, com tratamento pairwise, sugere uma estrutura empírica de 3 componentes que explica um conjunto de $85,26 \%$ da variância total da resposta (Tabela 10) dos participantes aos itens totais do questionário. Esta análise seguiram critério de eigenvalues (valores próprios) maiores ou igual a 1.

Tabela 10 - Variância total distribuída em 3 fatores.

\begin{tabular}{ccc}
\hline Fator & \% de Variância & Acumulado \% \\
\hline 1 & 38,91 & 38,91 \\
2 & 29,21 & 68,12 \\
3 & 17,14 & 85,26 \\
\hline
\end{tabular}

A análise de scree plot dá maior ênfase foi para uma estrutura de 3 fatores a serem extraídos, conforme Figura 2. 


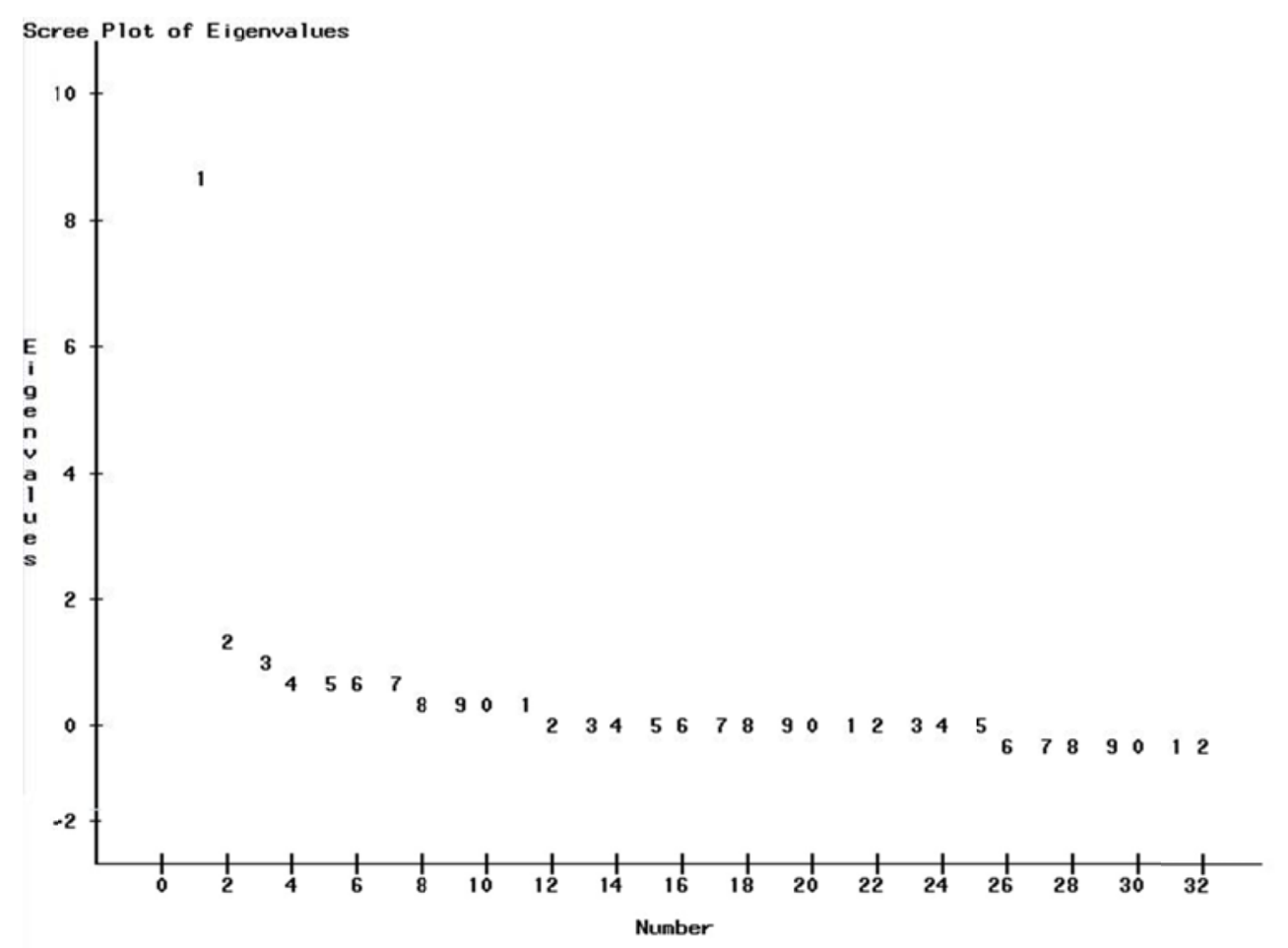

Figura 2 - Distribuição dos valores próprios (scree plot) do Questionário de Dificuldade de Tomada de Decisão.

A Tabela 11 apresenta a estrutura empírica das escalas com as devidas cargas fatoriais usando a rotação varimax. Foram incluídos na escala somente os itens cargas fatoriais superiores ou iguais a 0,30 .

Tabela 11- Carga fatorial dos itens do CDDQ distribuídos em 3 fatores.

\begin{tabular}{|c|c|c|c|}
\hline \multirow[t]{2}{*}{ Item } & \multicolumn{3}{|c|}{ Fator } \\
\hline & 1 & 2 & 3 \\
\hline $\begin{array}{l}14 \text { Eu acho complicado tomar decisões de carreira porque não sei que fatores considerar. (por } \\
\text { exemplo, fatores do seu contexto, individuais) }\end{array}$ & ,782 & & \\
\hline $\begin{array}{l}13 \text { Eu acho complicado tomar decisões de carreira porque não sei quais os passos que tenho que } \\
\text { adotar. }\end{array}$ & ,769 & & \\
\hline $\begin{array}{l}16 \text { Eu acho complicado tomar decisões de carreira porque ainda não sei bem que opções me } \\
\text { interessam }\end{array}$ & ,758 & & \\
\hline $\begin{array}{l}15 \text { Eu acho complicado tomar decisões de carreira porque não sei como combinar a informação que } \\
\text { tenho sobre mim com a informação acerca das diferentes carreiras. }\end{array}$ & ,756 & & \\
\hline $\begin{array}{l}17 \text { Eu acho complicado tomar decisões de carreira porque ainda não tenho certeza acerca das minhas } \\
\text { preferências }\end{array}$ & ,699 & & \\
\hline $\begin{array}{l}18 \text { Eu acho complicado tomar decisões de carreira porque não tenho informação suficiente acerca } \\
\text { das minhas competências e/ou acerca dos meus traços de personalidade. }\end{array}$ & 675 & & \\
\hline 4 Habitualmente, tenho dificuldade em tomar decisões & 671 & & \\
\hline $\begin{array}{l}21 \text { Eu acho complicado tomar decisões de carreira porque não tenho informação suficiente acerca } \\
\text { das características dos cursos e/ou profissões que me interessam. }\end{array}$ & 618 & & \\
\hline $22 \mathrm{Eu}$ acho complicado tomar decisões de carreira porque não sei como serão as carreiras no futuro. &, 593 & & \\
\hline
\end{tabular}


20 Eu acho complicado tomar decisões de carreira porque não tenho informação suficiente acerca da variedade de cursos ou profissões existente.

5 Geralmente, preciso da confirmação e do apoio de um profissional de orientação, ou de uma outra pessoa em quem confie, para tomar as minhas decisões de carreira.

28 Eu acho complicado tomar decisões de carreira porque sinto-me igualmente atraído/a por um conjunto de opções e é difícil para eu escolher entre elas.

$25 \mathrm{Eu}$ acho complicado tomar decisões de carreira porque mudo constantemente as minhas preferências de carreira (por exemplo, às vezes gostaria de ter um emprego por conta própria, enquanto que outras vezes gostaria de ser empregado).

6 Costumo ter medo do fracasso

19 Eu acho complicado tomar decisões de carreira porque não sei como serão as minhas capacidades e/ou traços de personalidade no futuro

$23 \mathrm{Eu}$ acho complicado tomar decisões de carreira porque não sei como obter informação adicional acerca de mim próprio/a

$24 \mathrm{Eu}$ acho complicado tomar decisões de carreira porque não sei como obter informação fidedigna e atualizada acerca das profissões e cursos existentes ou acerca das suas características

1 Sei que tenho que tomar uma decisão de carreira, mas não tenho a motivação necessária para a tomar neste momento ("não tenho vontade")

29 Eu acho complicado tomar decisões de carreira porque não gosto de nenhum dos cursos ou profissões em que posso ser admitido/a

$32 \mathrm{Eu}$ acho complicado tomar decisões de carreira porque as minhas capacidades e competências não se adequam às que são exigidas para o exercício da profissão em que estou interessado/a.

31 Eu acho complicado tomar decisões de carreira porque não consigo encontrar uma carreira que reúna todas as minhas preferências e não estou disposto/a ceder a nenhuma delas

$27 \mathrm{Eu}$ acho complicado tomar decisões de carreira porque tenho informações contraditórias acerca da existência ou de características particulares de um dado curso ou profissão.

$30 \mathrm{Eu}$ acho complicado tomar decisões de carreira porque a profissão em que estou interessado/a tem uma característica que me incomoda

$34 \mathrm{Eu}$ acho complicado tomar decisões de carreira porque as recomendações que vou recebendo, das pessoas que são importantes para mim, acerca da carreira que devo prosseguir, ou mesmo acerca das características das carreiras que devo considerar na minha decisão, são contraditórias

$26 \mathrm{Eu}$ acho complicado tomar decisões de carreira porque tenho informações contraditórias acerca das minhas capacidades e/ou acerca dos meus traços de personalidade

33 Eu acho complicado tomar decisões de carreira porque as pessoas que são importantes para mim, não concordam com as opções que eu considero e/ou com as características da carreira que eu quero prosseguir

3 Eu penso que não tenho que escolher uma carreira neste momento porque o tempo se encarregará de me levar a tomar a decisão "mais certa".

$2 \mathrm{O}$ trabalho não é o aspecto mais importante da vida das pessoas e, por isso mesmo, escolher uma carreira não é algo que me preocupe muito.

9 Eu acredito que há apenas uma carreira que se adequa a mim

11 Eu acredito que uma escolha desta natureza é realizada apenas uma vez na vida e será um compromisso para toda a vida.

$10 \mathrm{Eu}$ espero atingir todas as minhas aspirações através da carreira escolhida.

8 Ao exercer uma carreira que goste, estou também a resolver os meus problemas pessoais

Após a extração dos fatores, foi verificada a estabilidade e interpretabilidade dos mesmos. Para analisar a estabilidade, verificou-se o quanto os itens eram bons representantes do fator, pelo tamanho da carga fatorial: a correlação entre o item com o conjunto dos outros 
itens do fator (quanto mais próxima de 1 será melhor apresentada). As cargas fatorais de todos os itens foram iguais ou superiores a 0,30, estas apresentam variação de 0,78 a 0,35.

A partir desta análise podemos observar que o fator 1 compreende 18 itens sendo 12 itens que correspondem à categoria principal "Falta de Informação acerca de”. O Fator 1, em primeira análise da estabilidade passa a ser composto pelos itens:14, 13, 16, 15, 17, 18, 4, $21,22,20,5,28,25,6,19,23,24,1$ (na ordem de força fatorial). $O$ fator 2 compreende 8 itens da categoria principal “Dificuldade Devido a Informação Inconsistente”, sendo composto pelos itens: 29, 32, 31, 27, 30 34, 26, 33, 3; apresentados, também, na ordem da força fatorial.

O fator 3 que deveria corresponder à "Prontidão/ Estar Apto" somente compreendeu os itens 9,11,10,8; faltando os itens 1 a 6 do questionário original.

Para analisar a interpretabilidade, ao denominar os fatores e associá-los ao agrupamento dos itens, recorreu-se a literatura da área e a estrutura originária de CDDQ (OSIPOW; GATI , 2001) e a taxionomia proposta por Gati e Osipow (1996). Desta forma, as cargas fatoriais e a interpretação dos fatores ficaram assim distribuídas:

- Falta de Informação: (Fator 1)

14 Eu acho complicado tomar decisões de carreira porque não sei que fatores considerar. (por exemplo, fatores do seu contexto, individuais).

13 Eu acho complicado tomar decisões de carreira porque não sei quais os passos que tenho que adotar.

16 Eu acho complicado tomar decisões de carreira porque ainda não sei bem que opções me interessam

15 Eu acho complicado tomar decisões de carreira porque não sei como combinar a informação que tenho sobre mim com a informação acerca das diferentes carreiras.

17 Eu acho complicado tomar decisões de carreira porque ainda não tenho certeza acerca das minhas preferências

$18 \mathrm{Eu}$ acho complicado tomar decisões de carreira porque não tenho informação suficiente acerca das minhas competências e/ou acerca dos meus traços de personalidade.

$21 \mathrm{Eu}$ acho complicado tomar decisões de carreira porque não tenho informação suficiente acerca das características dos cursos e/ou profissões que me interessam. 
22 Eu acho complicado tomar decisões de carreira porque não sei como serão as carreiras no futuro.

$20 \mathrm{Eu}$ acho complicado tomar decisões de carreira porque não tenho informação suficiente acerca da variedade de cursos ou profissões existentes.

5 Geralmente, preciso da confirmação e do apoio de um profissional de orientação, ou de uma outra pessoa em quem confie, para tomar as minhas decisões de carreira.

28 Eu acho complicado tomar decisões de carreira porque me sinto igualmente atraído/a por um conjunto de opções e é difícil para eu escolher entre elas.

$25 \mathrm{Eu}$ acho complicado tomar decisões de carreira porque mudo constantemente as minhas preferências de carreira (por exemplo, às vezes gostaria de ter um emprego por conta própria, enquanto que outras vezes gostaria de ser empregado).

19 Eu acho complicado tomar decisões de carreira porque não sei como serão as minhas capacidades e/ou traços de personalidade no futuro

23 Eu acho complicado tomar decisões de carreira porque não sei como obter informação adicional acerca de mim próprio/a

24 Eu acho complicado tomar decisões de carreira porque não sei como obter informação fidedigna e atualizada acerca das profissões e cursos existentes ou acerca das suas características

Através da análise do conteúdo dos itens e a ideia proposta pela taxionomia, na qual a Falta de informação acerca do processo de tomada de decisão reflete a falta de conhecimento acerca da forma como se poderá chegar sensatamente a uma decisão e, especificamente, dos passos envolvidos no processo de tomada de decisão de carreira. Por exemplo, uma pessoa poderá não saber que fatores ter em conta, ou ter dificuldades em combinar a informação que detém sobre ela própria (pontos fortes e menos fortes) e a informação que detém acerca das diversas opções ocupacionais (que capacidades são requeridas numa ocupação específica) (GATI; KRAUSZ; OSIPOW, 1996)

Desta forma, podemos verificar que os itens 1 , 4, 5, 6 não corroboram a ideia do fator, estes originalmente fazem parte do Fator Prontidão. Por não ter pertinência de conteúdo, estes itens foram retirados. Desta forma o Fator 1 denominado Falta de Informação acerca do Processo de tomada de decisão passa a ser composto pelos itens: 13, 14, 15, 16, 17, 18, 20, 
21, 22, 23, 24, 25 e 28. Sendo 13 itens, apresentando 11 da escala original e 2 itens do Fator Dificuldade devido a Informação.

Já o segundo fator, após análise de interpretabilidade se apresenta:

- Dificuldade devido a Informação inconsistente (Fator 2)

$29 \mathrm{Eu}$ acho complicado tomar decisões de carreira porque não gosto de nenhum dos cursos ou profissões em que posso ser admitido/a

$32 \mathrm{Eu}$ acho complicado tomar decisões de carreira porque as minhas capacidades $\boldsymbol{e}$ competências não se adequam às que são exigidas para o exercício da profissão em que estou interessado/a.

31 Eu acho complicado tomar decisões de carreira porque não consigo encontrar uma carreira que reúna todas as minhas preferências e não estou disposto/a ceder a nenhuma delas

$27 \mathrm{Eu}$ acho complicado tomar decisões de carreira porque tenho informações contraditórias acerca da existência ou de características particulares de um dado curso ou profissão.

$30 \mathrm{Eu}$ acho complicado tomar decisões de carreira porque a profissão em que estou interessado/a tem uma característica que me incomoda

$34 \mathrm{Eu}$ acho complicado tomar decisões de carreira porque as recomendações que vou recebendo, das pessoas que são importantes para mim, acerca da carreira que devo prosseguir, ou mesmo acerca das características das carreiras que devo considerar na minha decisão são contraditórias

26 Eu acho complicado tomar decisões de carreira porque tenho informações contraditórias acerca das minhas capacidades e/ou acerca dos meus traços de personalidade

33 Eu acho complicado tomar decisões de carreira porque as pessoas que são importantes para mim, não concordam com as opções que eu considero e/ou com as características da carreira que eu quero prosseguir

A análise do conteúdo dos itens apontam para a retirada das questões 3 e 2 , pois estas originalmente propostas no fator original Prontidão não contém a ideia do fator 2 , que é carcterizado por itens que remetem a informações poucos consistentes e conflitos internos e 
externo com outros significativos da vida do indivíduo. Desta forma, o fator 2 passa a ser composto por 8 itens : 26, 27, 29, 30, 31, 32, 33 e 34 .

Já o fator 3 relativo à Prontidão, que é caracterizado por itens referentes a falta de morivação, indecisão generalizada e crenças disfuncionais, apresentou 4 itens dos 11 propostos no instrumento original, como é apresentado a seguir.

\section{- Prontidão (fator 3)}

9 Eu acredito que há apenas uma carreira que se adequa a mim

11 Eu acredito que uma escolha desta natureza é realizada apenas uma vez na vida e será um compromisso para toda a vida.

10 Eu espero atingir todas as minhas aspirações através da carreira escolhida.

8 Ao exercer uma carreira que goste, estou também a resolver os meus problemas pessoais

Desta forma apresentando apenas 4 itens do fator original, o resultado encontrado corrobora a literatura de que a escala principal Prontidão têm se revelado, em quase todos os estudos, com baixa confiabilidade. Dois estudos de Gati $(1996,1998)$ indicam que certas subescalas do CDDQ são menos refinadas do que outras. Assim, o referido autor destaca que a escala Prontidão é uma dessas escalas que necessitam de maior desenvolvimento em outras culturas.

Creed e Yin (2009) em seu estudo de validação da versão chinesa do CDDQ encontraram dois fatores, e não os três fatores do modelo original. Os dois grandes fatores encontrados relacionaram-se com as escalas: Falta de informação, apresentando17 itens sendo 12 itens originais, e Dificuldades devidas a Informação Inconsistente com 14 sendo 10 itens originais. Este estudo corrobora os dados encontrados nesta pesquisa. Estes autores identificaram, portanto dois fatores estáveis para o CDDQ, nomeadamente, a categoria Falta de Informação e Informação Inconsistente, mas falharam na confirmação do fator de Prontidão.

Já Mau (2001) com uma amostra americana $(\mathrm{N}=514)$ e taiwanesa $(\mathrm{N}=947)$, ao submeter o questionário a análise fatorial encontrou semelhança entre as estruturas das dificuldades do questionário a estrutura teórica nas duas amostras, apresentando 3 grandes fatores.

Por sua vez, Loureiro e Taveira (2010) no seu estudo, encontraram uma solução de 4 fatores, independentes e consistentes. A escala Falta de Informação e subescala Conflitos 
Internos formam um fator independente; a subescala Indecisão Generalizada e Conflitos Externos formam o fator 2; e as categorias Crenças Disfuncionais e Falta de Motivação formam outros dois fatores independentes.

Já Ussene e Taveira (2010), ao realizarem análise fatorial (PAF) encontraram as escalas da versão original divididas por nove fatores, sendo que as únicas escalas completas e consistentes são as Ocupações/Profissões, Falta de informação acerca de fontes adicionais de informação, que compõem o fator 1, e a Indecisão Generalizada que corresponde ao fator 4. Ussene e Taveira (2010) não conseguiu confirmar a escala original desenvolvidas por Gati e col. (1996), nem na sua adequação à amostra estudada.

Os resultados obtidos com a análise fatorial deste estudo ( 3 fatores com 28 itens) em questão, aproximaram-se da versão do modelo original de Gati e cols. (1996), porém não foi possível encontrar a solução com 10 fatores, relatadas em diversos estudos (MAU, 2001; GATI; KRAUSZ; SAKA, 2000; ALBION; FOGARTY, 2002) que se mostraram mais refinados na obtenção de subescalas. A taxionomia e o instrumento foram testados e receberam suporte empírico em diversas investigações (GATIet al, 1996; GATI; OSIPOW, 2000; GATI; SAKA, 2001; LANCASTERet al, 1999; MAU, 2001). Porém, a maior parte dos estudos de validação foi feita com Análises de Cluster, que verificou existir uma boa correspondência entre o modelo teórico e os dados empíricos.

O presente estudo, que avaliou a validade por meio de análise fatorial, a estrutura de 3 fatores, mostrou-se mais adequada com a retirada de seis itens ficando assim com 28 itens. Os seis itens retirados compunham o fator Prontidão, o que se pode notar e que este fator mostrou-se frágil corroborando com a literatura explicitada.

Desta forma, com os resultado da validade fatorial, o presente questionário divide-se em 3 fatores num total de 28 itens dos 34 da escala original. Para a interpretação da confiabilidade abaixo serão listados os resultados com esta nova estrutura.

Ao nível da validade fatorial do CDDQ registam-se resultados satisfatórios, estrutura fatorial (3 fatores), no qual foi possível alcançar a taxionomia proposta por Gati e col. (1996). Foram englobadas, neste estudo, todas as categorias de dificuldades descritas pelo taxionomia original. Na verdade foi encontrada uma solução de três fatores que preenchem de forma consistente e independente as escalas, nomeadamente, a escala Falta de Informação, Dificuldade devido à informação inconsistente e Prontidão embora o Fator 3 apresente apenas 4 itens. 


\subsubsection{Análise Fatorial Confirmatória}

A fim de comprovar a estrutura fatorial do CDDQ (3 fatores), realizou-se uma Análise fatorial Confirmatória. A análise confirmatória impõe aos dados uma estrutura teórica preliminar e verifica, em seguida, se esta se adapta aos dados empíricos expressos pela a matriz, ou seja, ela testa a hipótese preliminar sobre os fatores e as cargas fatoriais (PASQUALI, 2004). Para se efetuar uma análise fatorial confirmatória é preciso impor aos dados uma estrutura preliminar definida em termos substantivos, verificar uma hipótese, no caso a taxionomia proposta pelos autores do CDDQ (GATI; OSIPOW, 1996). Neste estudo a identificação do modelo da análise confirmatória foi dada a partir da taxionomia de dificuldade de tomada de decisão proposta por Gati e colaboradores (1996).

Partindo-se da hipotética associação entre as três dimensões do construto avaliado para a amostra $(\mathrm{n}=500)$, a adequação do modelo fatorial confirmatório foi testada usando os seis seguintes critérios: qui-quadrado, razão entre qui-quadrado e graus de liberdade, GFI (Goodness-of-fit Index), AGFI (Adjusted Goodness-of-Fit Index), a RMR (Root Mean Square Residual) e RMSEA (Root Mean Square Error of Approximation).

Critérios múltiplos foram utilizados uma vez que cada índice apresenta diferentes forças e fraquezas na avaliação da adequação do modelo fatorial confirmatório (TAYLOR, BAGBY; PARKER, 2003). São eles: ( 1 ) o teste Qui-quadrado deve ser não significativo; ( 2 ) a razão entre qui-quadrado e graus de liberdade deve ser menor que 5 (em valores nominais) ou, desejavelmente, menor que 2; ( 3 ) o GFI deve apresentar um índice superior ou igual a 0,85; ( 4 )o AGFI deve apresentar um índice superior ou igual a 0,80; e, finalmente, ( 5 )o RMR deve apresentar um índice inferior ou igual a 0,10 e o ( 6 ) RMSEA deve apresentar coeficiente inferior a 0,05 (ANDERSON; GERBING, 1984; BALBINOTTI, 2005; COLE 1987; MARSH; BALLA; MCDONALD, 1988; BROWNE; CUDECK, 1993). Para os resultados obtidos nessas análises foi utilizado o procedimento PROC CALIS do software SAS 9.2, cujos resultados são apresentados na Tabela 12. 
Tabela 12 - Índices de validade fatorial confirmatória.

\begin{tabular}{llll}
\hline Índice & Resultado & \multicolumn{2}{c}{ Satisfatório } \\
\hline Goodness of Fit Index (GFI) & 0,82 & $\geq 0,85$ & $\mathrm{X}$ \\
GFI Adjusted for Degrees of Freedom (AGFI) & 0,79 & $\geq 80$ & $\mathrm{OK}$ \\
Root Mean Square Residual (RMR) & 0,06 & $\leq 0,10$ & $\mathrm{OK}$ \\
Qui-quadrado / Graus de liberdade & $682,33 / 461=1,48$ & $<2$ & $\mathrm{OK}$ \\
Pr $>$ Chi-Square & $<0,01$ & $>0,05$ & $\mathrm{X}$ \\
RMSEA Estimate & 0,05 & $<0,05$ & $\mathrm{OK}$ \\
\hline
\end{tabular}

A análise fatorial confirmatória apresenta distintas vantagens sobre a análise fatorial exploratória, principalmente porque ela parte de uma teoria e um modelo teórico que procura impor aos dados, o que combina com a metodologia científica do teste das hipóteses (PASQUALI, 2004).

Através dos resultados da Tabela 12, que dos seis critérios utilizados, quatro mostraram resultados satisfatórios. O GFI apresentou resultado próximo ao considerado satisfatório e o qui-quadrado mostrou um resultado insatisfatório, porém, resultados insatisfatórios para os critérios 1 e 2 são tipicamente encontrados em grandes amostras, como é o caso. Por essa razão, alguns autores (COLE, 1987; MARSH et. al, 1988) têm descartado, especialmente o qui-quadrado de suas análises, pois se trata de uma estatística extremamente sensível ao número de sujeitos da amostra.

Desta forma, pode-se concluir que a análise fatorial confirmatória verificou que o CDDQ apresenta índices, de validade fatorial confirmatória, satisfatórios. Estes resultados permitem assumir a validade de construto do CDDQ.

\subsection{Confiabilidade do CDDQ}

Para o estudo da consistência interna da escala foi usado o índice alfa de Cronbach (CRONBACH, 1951), com a estrutura de 28 itens. Os resultados obtidos apontam para um índice de confiabilidade geral do questionário de $\alpha=0,92$. Apresentando índices de 0,58 para o fator de Preparação; 0,92 para o fator de Falta de Informação e de 0,86 para o fator Informações Inconsistentes (Tabela 13). 
Tabela 13 - Índices do alfa de Cronbach para o CDDQ.

\begin{tabular}{ll}
\hline Confiabilidade - Alfa de Cronbach & \\
\hline Falta de preparação & 0,58 \\
Falta de informação & 0,92 \\
Informações Inconsistentes & 0,86 \\
\hline Total do questionário & 0,92 \\
\hline
\end{tabular}

Retomando os critérios apresentado na metodologia, os autores Garson (2005), Pestana e Gageiro (2003), Nunnally (1978) e Taylor e colaboradores (2003) recomendam que a adequação e a satisfatoriedade do modelo alfa sejam testadas usando-se os seguintes critérios: índices alfa superiores a 0,80 são considerados desejáveis; índices superiores a 0,70 são considerados recomendados; índices superiores a 0,60 devem ser aceitos apenas para uso em pesquisa (desaconselhável o uso clínico). Sendo assim a consistência interna dos itens do CDDQ mostrou-se satisfatória, segundo os critérios explicitados neste estudo.

Pode-se observar (Tabela 13) que a escala Prontidão/Falta de preparação, como referido acima, apresentou valor de confiabilidade interna de 0,58, o que se mostra baixo, sendo aconselhável apenas para uso em pesquisa (GARSON, 2005).

Nos resultados de análise dos itens é possível verificar uma consistência interna positiva para o questionário total, sendo 0,92, porém o fator Prontidão apresenta consistência menor, variando de 0,56 a 0,63 (Tabela 1) o que corrobora os achados de outros estudos (USSENE; TAVEIRA, 2010; LOUREIRO; TAVEIRA, 2010; ALBION; FOGARTY, 2002; MAU, 2001; GATI; SAKA, 2001).

Inicialmente, o estudo de confiabilidade do CDDQ foi realizado em dois grupos diferentes, um de Israel e o outro nos Estados Unidos (GATI e cols, 1996). Na amostra Israelense o coeficiente de alfa mediano de 0,78 e o coeficientes teste- reteste mediano de 0,65 (Tabela 1 e 2); na amostra americana apenas foi medida a consistência interna, senão a mediana dos coeficientes de 0,77. Para o resultado total do CDDQ, o alfa de Cronbach foi de 0,95. Estudos realizados posteriormente têm em geral revelado valores similares. Existem evidências que a maioria dos valores de consistência interna, estão localizados em um intervalo que vai de moderado a elevado (SILVA, 2004), como apresenta os estudos a seguir.

Gati e Saka (2001), em seu estudo, citado anteriormente, de validação com uma amostra de 1772 alunos israelenses do ensino médio, encontrou alfa de 0,58 para escala Prontidão; com outra amostra de Jovens adultos israelenses $(\mathrm{N}=417)$ estes mesmos autores 
encontraram alfa de 0,61. O que, também, foi evidenciado por Mau (2001), com sua amostra taiwanesa obteve alfa de 0,55. Neste sentido, como relatado pela literatura, o fator Prontidão/Falta de Preparação mostrou-se frágil quanto a sua consistência interna em vários estudos com população internacional.

Assim como Silva e Ramos (2008), o presente estudo verificou que fatores que descrevem dificuldades que ocorrem durante o processo de tomada de decisão de carreira (Falta de Informação e Informação inconsistente) são mais confiáveis do que a escala falta de prontidão, que ocorreria anteriormente à tomada de decisão.

Outro estudo que apontou a mesma tendência, de Ussene e Taveira (2010), que confirmaram uma maior consistência para as dificuldades relacionadas com a Falta de Informação $(0,78)$ e Informação Inconsistente $(0,81)$, em relação à escala Falta de Prontidão $(0,61)$.

Já Taveira e Loureiro (2010) em estudo da escala com 163 universitários apresentaram altos índices de confiabilidade são de salientar, os valores dos coeficientes de consistência interna elevados, para as escalas, subescalas e total do CDDQ com 0,90 na escala Falta de Prontidão, 0,92 na subescala Crenças Disfuncionais, e 0,89 na escala do total do CDDQ. Porém, as autoras concluíram que seria adequado prosseguir com a replicação deste estudo exploratório, com amostras maiores de alunos do ensino superior, colocando esta, como uma das principais limitações da sua investigação, o que poderia afetar os índices de confiabilidade.

Osipow e Gati (1998) propuseram que a baixa confiabilidade do fator Prontidão poderia estar associada ao pequeno número de questões que compõem esta escala. Em um estudo Gati e Saka (2001) abordaram de forma empírica esta questão, aumentando o número de itens desta escala, o que gerou um resultado mais elevado. O que pode justificar os baixos resultados de confiabilidade do fator Prontidão, neste estudo, que após a análise fatorial, o Fator Prontidão apresentou 4 itens dos 11 propostos no questionário original. Os resultados do Fator Prontidão devem ser vistos com cautela, não devendo ser utilizados em pesquisas ou diagnóstico em separado do questionário total.

Finalmente, no que se diz a confiabilidade dos resultados apurados nas pesquisas relatadas e neste estudo que são maioritariamente razoáveis e bons, embora apresente escala que suscitam certas reservas. 


\subsection{Validade por referência a critério}

A validade por referência a critério foi, durante muito tempo, a única e a mais importante forma de validar um teste. Ela está intimamente ligada ao primeiro conceito a que a expressão "validade" aparece associada (grau em que o teste mede aquilo que pretende medir) (GUION, 1974 apud ALMEIDA FREIRE, 1997 ). Trata-se, pois, do tipo de validade que decorre da perspectiva psicométrica de observação (desempenhos e comportamentos em geral como reflexo de fatores internos a avaliar, testes como "bons" instrumentos de avaliação das dimensões internas, estabilidade das dimensões e possibilidade de boas inferências atuais e futuras a partir dos resultados nos testes para outras situações) (ALMEIDA; FREIRE, 1997).

O presente estudo utilizou-se de uma questão de autoavaliação, sobre a dificuldade de tomada de decisão para a carreira, representada pela questão: "Finalmente, como você pontua seu grau de dificuldade de Tomada de Decisão para a carreira?" que foi medida através de uma escala de likert de 9 pontos, em que 1 representava Baixa dificuldade de Tomada de Decisão para a carreira, e 9 Alta dificuldade, e seus níveis intermediários mostravam graduações nesta autoavaliação.

Outros estudos com CDDQ (OSIPOW, GATI, 1998; LANCASTER, 1999; SIMÕES, 2010), também analisaram aspectos relativos a validade convergente através da validade por referência de critério.

Como aponta o estudo de Simões (2010) que utilizou uma questão para definir os decidios e indecisos, a partir de um critério de autoavaliação. Neste estudo com CDDQ em alunos portugueses do $9^{\circ}$ ano, separou a amostra em decididos e não decididos, através de pergunta no questionário (usando critério de autoavaliação dos mesmos): "Já considerou qual a área em que gostaria de se especializar ou qual a ocupação que gostaria de escolher?" permitiu- constituir dois grupos: os participantes que responderam "sim", denominados de decididos ( $n=124)$, e os que responderam "não", denominados de indecisos $(n=64)$. A partir destes grupos, a autora utilizou-se de uma MANOVA correlacionando os dados com os fatores encontrados em seu estudo. Os resultados para a MANOVA indicam a existência de diferenças estatisticamente significativas entre os dois grupos (Wilks's Lambda= 0,93; F (4, $183)=3,24, \mathrm{p}<<.05)$. Os resultados indicam que o grupo de alunos decididos apresenta menos dificuldades que o grupo de indecisos, sendo este um modelo de validade por referência a critério com utilização do CDDQ.

O presente estudo, por utilizar-se de um critério de autoavaliação medido em escala tipo like,t optou pelo coeficiente de correlação de Pearson, também chamado de "coeficiente de correlação produto-momento" ou simplesmente de " $\rho$ de Pearson", que mede o grau da 
correlação (e a direção dessa correlação - se positiva ou negativa) entre duas variáveis de escala métrica (intervalar ou de razão). Já que, como citado, o instrumento obtêm seu resultado em uma escala de likert de 9 pontos, e a questão de autoavaliação, também. Este coeficiente, normalmente representado por $\rho$ assume apenas valores entre -1 e 1 . Se $\rho=1$, apresenta significativa correlação perfeita positiva entre as duas variáveis, e se $\rho=-1$ representa uma correlação negativa perfeita entre as duas variáveis.

Encontrou-se como resultado que todos os fatores apresentaram valores significativos relacionados às variáveis de Dificuldade de Tomada de Decisão na Carreira, se relacionavam positivamente com Prontidão ( $r=0,45 ; \mathrm{p}<0,001)$, Falta de Informação $(r=0,67 ; \mathrm{p}<0,001)$ e Dificuldade Devido a Informação Inconsistente $(r=0,62 ; p<0,001)$ significando que quanto maior o escore de autoavaliação em apresentar dificuldade na tomada de decisão para a carreira, maior os escores nos fatores que compõem o questionário de dificuldade de Tomada de decisão para a carreira. O que confirma a hipótese apresentada, de que o questionário mede a dificuldade de tomada de decisão para a carreira, pois se o participante deste estudo apresentou alto escore no questionário este aponta para uma Dificuldade em tomar decisões referentes à carreira.

Como se trata de estudantes universitários que já realizam a primeira escolha - do curso de graduação - as dificuldades apresentadas no final do curso referem-se às decisões para prosseguimento da carreira, ou seja, a inserção no mercado de trabalho ou o prosseguimento dos estudos em nível de aprimoramento profissional ou de realização de cursos de pós-graduação lato sensu ou stricto sensu.

Finalmente, visando complementar as análises exploratórias das estruturas empíricas para identificar possíveis diferenças significativas de variáveis demográficas e de Dificuldades de Tomada de Decisão na Carreira. Foram feitas análises com o objetivo de comparar as variáveis: sexo, faculdade, inserção, trabalho e estágio, utilizando-se para tal teste não paramétrico de Wilcoxon (para amostras independentes), o qual testa a hipótese nula de que os grupos foram tomados de uma mesma população, contra a hipótese alternativa de que os dois grupos vêm de populações distintas. Para a realização desta metodologia foi utilizado o procedimento PROC NPAR1WAY do Software SAS 9.2.

Para comparação das variáveis estado civil, nível de confiança, classe social, faixa etária e área de curso foi utilizado o teste não paramétrico de Kruskal-Wallis para as variáveis dependentes, objetivando detectar quais grupos diferem dois a dois. Estes testes foram feitos através da PROC IML do software SAS. Os resultados não foram apresentados aqui, pois não fazem parte do atual objetivo do trabalho, porém servem de base para corroborar a discussão apresentada e fundamentar futuros estudos com o instrumento. As tabelas com os resultados foram expostas nos Apêndices A, B, C, D, F e G. 
6. CONSIDERAÇÕES FINAIS 

Diante da proposta original e do percurso decorrido na realização desta investigação, considera-se que o presente trabalho atingiu os objetivos propostos. Os resultados obtidos com o CDDQ confirmam a confiabilidade, validade semântica, fatorial e de referência por critério.

O presente estudo buscou ampliar as discussões sobre a decisão e indecisão de carreira no contexto universitário, por meio de um instrumento de avaliação. A decisão e a indecisão vocacional constituem um dos campos da Psicologia Vocacional que tem usufruído de uma notoriedade entre os investigadores desta área (Silva, 2004). Ainda assim, o construto permanece insuficientemente definido e clarificado o que justificam as investigações sobre o fenômeno e instrumentos de medida que o avaliam.

O interesse pela questão da indecisão e decisão quanto à escolha profissional, ou de uma forma mais ampla, com a construção de um trajeto de vida, sempre estiveram presentes desde os pioneiros da Psicologia Vocacional, como Parsons no início do século passado, porém este fenômeno era estudado e pesquisado de forma bastante rudimentar, apenas com perguntas, sobre a decisão ter sido feita ou não. Na segunda metade do século $\mathrm{XX}$, pesquisadores norteamericanos, deram início ao processo de criação de instrumentos de medida, alicerçados na Psicometria (OSIPOW, BARCK, 1976; HOLLAND; NICHOLS, 1964), construindo assim instrumentos que puderam auxiliar no entendimento da decisão e da indecisão ao longo da carreira e da vida.

Neste sentido, o CDDQ, sendo um instrumento que apresenta o objetivo de aferir as dificuldades de tomada de decisão para a carreira, apontando caminhos para se entender esse construto, possibilitou a investigação proposta com esse instrumento, contribuindo, assim, com o campo do Desenvolvimento de Carreira, neste estudo circunscrevendo à realidade de universitários.

O esforço deste estudo para a validação do CDDQ, com uma amostra da população universitária brasileira, apresenta-se como uma tentativa de contribuir com as investigações sobre instrumentos já desenvolvidos e dar suporte a futuras pesquisas que focalizem a questão da dificuldade de tomada de decisão de careira em universitários. Neste sentido, nos últimos dez anos, o Career Decision-Making Difficulties Questionnaire (CDDQ) desenvolvido por Gati, Krausz e Osipow (1996) tem vindo a revelar-se um instrumento de medida promissor acerca da indecisão de carreira, nomeadamente, dos fatores que contribuem para explicar as dificuldades de tomada de decisão, ou parte delas, de acordo com a taxonomia proposta, antes e durante o processo de tomada de decisão. 
Assim, o estudo em causa, teve com objetivo a realização da análise exploratória ao nível da consistência interna e da validade interna do questionário de Dificuldades de Tomada de Decisão de Carreira, na sua versão com 34 questões. Quanto à consistência interna do CDDQ registram-se resultados satisfatórios, assim como a confirmação da taxonomia proposta por Gati e colaboradores (1996). Foi possível, englobar neste estudo todas as categorias de dificuldades descritas pelo autor. Após a análise fatorial foram encontrados 3 fatores que preenchem consistentemente e independentemente as escalas propostas. Apesar da retirada de 6 itens que não apresentavam representação de conteúdo no fator que foram alocados, estes não alteraram a confiabilidade geral do instrumento. Os resultados de confiabilidade (consistência interna) foram satisfatórios, embora o coeficiente de alfa de Cronbach para o fator Prontidão seja o valor mais baixo $(0,58)$, já o restante dos valores variam de 0,86 a 0,92 .

A análise fatorial confirmatória realizada, também, apontou para uma solução com 3 fatores, confirmando os achados em estudos desta natureza; isto é, dos seis critérios utilizados, quatro mostraram resultados satisfatórios, o que permite assumir a validade de construto do CDDQ. Na validade por referência de critério, foi utilizado um critério de autoavaliação, pois há uma escassez de instrumentos padronizados brasileiros que mede tomada de decisão para o público universitário. Os resultados dessa validação mostraram-se satisfatórios apontando que quanto maior a autoavaliação de dificuldade de tomada e de decisão para a carreira, maior são os escores nos fatores e no questionário total, porém esta validade deve ser analisada com cautela, devido à falta de instrumentos padronizados para a comparação. Desta forma, sugere-se que em futuras investigações com o CDDQ outros tipos de critérios sejam testados.

Este estudo apresenta algumas limitações, no que se refere à inviabilidade de se reescrever os itens, como explanado anteriormente. Outra limitação refere-se à escala Prontidão, que não deverá ser utilizada em separado do questionário geral, apresentando poucos itens e baixa confiabilidade, este dado corrobora a literatura. e aponta a necessidade de novas investigações.

Embora os resultados obtidos com este estudo sejam encorajadores, sugere-se a continuidade de investigações com o CDDQ para utilização com universitários, assim como uma reflexão sobre outras variáveis que influenciam a construção da carreira de estudantes, entre elas, o sistema de acesso às universidades - o exame vestibular -,o modelo de Educação Superior brasileiro, ou seja as diversas e complexas condições facilitadoras ou que dificultam o processo de tomada de decisão para a carreira ao longo da vida. 
Neste sentido, faz-se pertinente a continuação dos estudos com o instrumento em questão. Um caminho pode ser a análise qualitativa e descritiva das respostas aos itens do questionário que foram validados, objetivando análise do perfil de universitários, em função do sexo e da natureza das instituições (públicas e privadas), entre outras variáveis. Portanto, sugere-se analisar de forma qualitativa os achados nas respostas dos universitários e repensálas à luz do atual sistema educacional brasileiro, das exigências que a sociedade contemporânea requer dos profissionais do futuro e dos novos paradigmas no que se refere à construção da carreira.

Os achados deste estudo mostram que ainda é preciso investigar mais sobre como as "decisões de carreira" são percebidas por universitários, uma vez que no contexto brasileiro, as preocupações com a "tomada de decisão de carreira" são mais frequentes na passagem do Ensino Médio para a Universidade, por meio do exame vestibular. Tomada tal decisão e tendo ingressado na universidade muitos pensam que a tarefa da "escolha" foi concluída. Porém, durante o curso universitário, os estudantes se defrontam com inúmeras situações que requerem tomadas de decisão, como escolha de disciplinas optativas e de estágios, a participação em projetos de pesquisas para a iniciação científica, possibilidades de intercâmbio internacional, entre outras situações. Além disso, o nível de comprometimento com o curso e o grau de envolvimento nas tarefas acadêmicas podem constituir fatores que facilitam ou dificultam a construção da carreira. É consenso que dimensões psicológicas e os contextos socioeconômicos e culturais afetam a vida e indubitavelmente a construção da carreira em qualquer etapa do ciclo vital, assim, há pessoas que necessitam de ajuda.

Objetivando favorecer a tomada de decisão consciente e autônoma do universitário defende-se a implantação e a avaliação de Programas de Planejamento e Gestão da Carreira, destinados a pessoas que deles necessitam (destaca-se que não são todas), em diferentes cursos universitários, relativamente similares aos tradicionalmente existentes em cursos de Medicina, porém dentro de uma lógica que fundamenta a Educação para a Carreira - outra área de investigação e intervenção -, que focaliza todos os níveis educacionais e centra-se nas questões de carreira ao longo da vida. Destaca-se, ainda, que novos paradigmas como os da construção da carreira ou construção da vida (DUARTE, 2009), são recomendáveis para programas que objetivam intervir com trabalhadores de uma nova era, a da informação e das redes da internet. Segundo a referida autora, partindo do estudo da carreira profissional, passou-se para o estudo do desenvolvimento da carreira, e a área - com um grupo de pesquisadores de diversos países - encontra-se desenvolvendo estudos com base no paradigma da construção da vida (life designing). É nesse contexto de mudanças no mundo, 
no trabalho e nas organizações, nas pessoas, e, sobretudo, no domínio da Orientação Profissional e de Carreira que se defende a implantação de programas de intervenção e o desenvolvimento e a avaliação de instrumentos de medida e da prática profissional.

Desta forma, a continuação dos estudos do CDDQ dentro de programas sistematizados de Desenvolvimento e Gestão de Carreira com universitários mostra-se pertinente. Porém, mais relevante ainda, são as políticas públicas de desenvolvimento de carreira em todos os níveis educacionais. Considerando o foco do presente estudo, destacam-se as políticas públicas de qualificação do profissional, incluindo estratégias para a construção da carreira em um mundo em permanente mudança. Desta forma, seria interessante que o CDDQ fosse pesquisado em Programas sistematizados de Desenvolvimento e Gestão de Carreira para universitários, obtendo assim maiores parâmetros para a discussão dos itens apresentados e sobre o fenômeno da decisão na passagem da universidade para o trabalho no contexto brasileiro. 


\section{REFERÊNCIAS $^{4}$}

\footnotetext{
${ }^{4}$ Segundo referenciais: Diretrizes para apresentação de dissertações e teses da USP: documento eletrônico e impresso- Parte I ABNT (2009).
} 

ALBION, M. J.; FOGARTY, G. J. Factors Influencing Career Decision Making in Adolescents and Adults. Journal os Career Assessment , v. 10, n. 1, p. 91-126, 2002.

ALMEIDA, L. S.; SOARES, A. P. Os estudantes universitários: sucesso escolar e desenvolviemtno psicossocial. In: MERCURI, E.; POLYDORO, S. A. J. O. Estudantes Universitários: características e experiências de formação. $1^{\circ}$. ed. Taubaté: Cabral Editora e Livraria Universitária, 2003.

ALMEIDA, L.; FREIRE, T.. Metodologia da Investigação em Psicologia e Educação. Coimbra: APPORT, 1997.

ANDERSON, J. C.; GERBING, D. W. The effect of sampling error on convergence, improper solutions, and goodness-of-fit indices for maximum likelihood confirmatory factor analysis. Psychometrika,v 49, p. 155-173,1984.

BADARGI, M. P.; LASSANCE, M. C. P.; PARADISO, A. C. Trajetória acadêmica e satisfação com a escolha profissional de universitários em meio de curso. Revista Brasileira de Orientação Profissional, v.4, n.13,p. 153-166, 2004

BARDAGI, M. P.; BOFF, R. M. Autoconcenito, autoeficácia profissional e comportamento exploratório em universitários concluintes. Avaliação: Revista da Avaliação da Educação superior. Sorocaba, v. 15, n. 1, p. 41-56, 2010.

BALBINOTTI, M. A. A. Para se avaliar o que se espera: reflexões acerca da validade dos testes psicológicos. Aletheia, v. 1, n. 21, p.43-52, 2005

BASTOS, S. M. Diagnóstico das dificuldades que o concluinte de psicologia espera encontrar para se engajar no mercado de trabalho. Dissertação de Mestrado: Universidade Federal do Pará, 1997.

BRASILMinistério da Educação. Secretaria de Educação Média e Tecnológica. Decreto $\mathrm{n}^{\circ} 5.154$, de 23 de julho de 2004. Regulamenta o $\S 2^{\circ}$ do art. 36 e os arts. 39 a 41 da Lei no9.394, de 20 de dezembro de 1996. Brasília: MEC/SEMTEC, 2004a. Disponível em: $<$ http://www6.senado.gov.br/legislacao/ListaPublicacoes.action?id=238991 $>$. Acesso em: 17 julho 2011.

BRÊDA, M. Decisão de Carreira, norma e sujeito agêntico. Psychologica, v. 26, p. 105-134, 2001.

BROWNE, M. W.; CUDECK, R. Alternative ways of assessing model fit. In: K. A. BOLLEN, L. S. LONG (Orgs.), Testing structural equation models. pp. 136-162. Newbury Park, Califórnia: Sage, 1993. 
BUHL, H. M. Well- Being and the child-parents relationship at the transition from University to work life. Journal of adolescent resarch, Jena, v. 22, n. 5, p. 550-571, 2007.

CALEGARI, M. M. A inserção profissional de egressos universitários. Dissertação de Mestrado - PUCRGS/SP. 2001.

CAMPOS, B. P. Consulta psicológica nas transições desenvolvimentais. Cadernos de Consulta psicológica, v. 9, p. 5-9, 1993.

CHAVACCI, D. Transition to University to work under transformation: The challenge roleof institucional and Alummini Networks in Contemporary Japan. Social Science Japan Journal, v. 8, n. 1, p. 19-41, 2005.

COELHO, J. A. Organizações e carreiras sem fronteiras: a percepção dos formados sobre a tendência nas exigências profissionais. IP/USP, Dissertação de Mestrado, 2000.

COLE, D. A. Utility os confirmatory factor analysis in test validation reserach. Journal of Consulting and Clinical Psychology, v. 55, p. 584-594, 1987.

COLOZZI, E. A. Systematic career guidance services. A systematic approach to delivery career guidance services. Material não publicado apresentado em Congresso National Career Development Association, São Francisco, Julho 2004.

CRONBACH, L. J. Coefficient alpha and the internal structure of tests. Psychometrika, 16, 297-334,1951.

DEL PRETRE, Z.; DEL PRETE, A. No contexto da travessia para o ambiente de trabalho:treinamento de habilidades sociais com universitários. Estudos de Psicologia, v. 8, p. 413-420, 2003.

DUARTE, Maria Eduarda. Um século depois de Frank Parsons: escolher uma profissão ou apostar na psicologia da construção da vida? Rev. bras. orientac. prof, São Paulo, v. 10, n. 2, dez. 2009 . Disponível em $<$ http://pepsic.bvsalud.org/scielo.php?script=sci_arttext\& pid=S1679-33902009000200003\& lng=pt\&nrm=iso $>$. acessos em 21 fev. 2012.

ERICKSON, E. H. Identidade Juventude e Crise. 2. ed. Rio de Janeiro: Guanabara, 1987.

FACHEL, J. M. G.; CAMEY, S. Avaliação psicométrica: a qualidade das medidas e o entendimento dos dados. In: CUNHA, J. A. et al.. Psicodiagnóstico - V. Porto Alegre: Artes Médicas, 2000. p. 158-170. 
GATI, I.; KRAUSZ, M.; OSIPOW, S. H. A taxonomy of difficulties in carrer decision making. Journal of Counseling Psychology, p. 43,510-526, 1996.

GATI, I. Using career-related aspects to elicit preferences anda characterize occupations for better person-enviromnment fit. Journal os Vocational Behavior, v. 52, p. 343-356, 1998.

GATI, I. et al. Perceived benefits of using an internet-based interactive career planning system. Journal of Vocational Behavior, v. 62, p. 272-286, 2003.

GATI, I. et al. Perceived benfits of using an internet-based interactive career planning system. Journal of Vocational Behavior, v. 62, p. 272-286.

GATI, I. et al. Validity of the career decison-making difficulties questionnaire: Counseless'versus counsellors'perceptions. Journal of Vocational Behavior, v. 56, p. 99113.

GATI, I.; ASHER, I. The PIC model for career decision making: Prescreening, in-deppth exploration ande choice. In: LEONG, F.; BARACK, A. Contemporary models in vocational psychology. New Jersey: Mahwah, 2001. p. 7-54.

GATI, I.; GARTY, Y.; FASSA, N. Using career-related aspects to assess person-environment fit. Journal of Counselig Psychology, v. 43, p. 196-206, 1996.

GATI, I.; HOUMINER, D.; AVIRAM, T. Career Compromises: Framings an Their implications. Journal of Couseling Psychology, v. 45, p. 505-514, 1998.

GATI, I.; HOUMINER, D.; AVIRAM, T. Career Compromises: Framings an Their implications. Journal os Counseling Psychology, v. 45, p. 505-514.

GATI, I.; KRAUSZ, M.; OSIPOW, S. A taxonomy of difficulties in career decison-making. Journal of Vocational Behavior, v. 56, p. 99-113, 1996.

GATI, I.; SAKA, N. Internet-based versus paper-and-pencil assessment: Measuring career decision-making difficulties. Journal os Career Assessment, v. 9, p. 397-416, 2001.

GATI, I.; TAL, S. Decision- Making Models and Career Guidance. In: ATHANASOU, A.; ESBROECK, V. International Handbook osf Career Guidance. Berlim: Springer Media, 2008. p. 157-185. 
GATI, I.; KRAUSZ, M.; SAKA, N. Validity of the Career Decision- Making Difficulty Questionnaire: Counseless' versus career counselor's perceptions. Journal od Counseling Development, n. 56, p. 99-113, 2000.

GATI, I.; SAKA, N. High school studentes'career- related decision-making difficulties. Journal of Counseling and Development, n. 79, p. 331-340, 2001.

GELATT, H. B. Positive uncertainty; nem decision-making framework foe couseling. Journal of Couseling Psychology, v. 36, n. 2, p. 252-256, 1989.latt, H. B. (1989). Positive uncertainty: a new decision-making framework for counseling. Journal of Counseling Psychology, vol. 36, 2, 252-256.

GUNTHER, H. Como elaborar um questionário. Série: Planejamento de Pesquisa nas Ciências Sociais, n. 01, p. 1-15, 2003.

HORA H. R., MONTEIRO, G. T.; ARICA, Confiabilidade em Questionários para Qualidade: Um Estudo com o Coeficiente Alfa de Cronbach, Produto \& Produção, vol. 11, n. 2, p. 85 103,2010 .

JEPSEN, D.; DILEY, J. Vocational decision-models: a review ande comparative analysis. Review of Educational Research, v. 44, n. 3, p. 331-349, 1974.

JENSCHEKE, B. Educação Profissional em escolas em um perpectiva internacional. In: LEVENFUS, R. S.; SOARES, D. H. P. Orientação vocacional ocupacional: Novos achados teóricos, técnicos e instrumentais para a clínica, a escola, a empres. São Paulo: ArtMed, 2002.

LEVENFUS, R. S.; SOARES, D. H. P. Orientação vocacional ocupacional: Novos achados teóricos, técnicos e instrumentais para a clínica, a escola, a empres. São Paulo: ArtMed, 2002.

KELLY, K. R.; LEE, W. C. Mapping the domain of career decision problems. Journal of Vacational Behavior, n. 41, p. 302-326, 2002.

KLEIMAN, T. et al. Dysgunctional thinking and difficulties in career decision making. Journal os Carrer Assessment, n. 12, p. 312-331, 2004.

KONIGESTED, M. Educação e Carreira: Estudo de avaliação da eficácia de uma intervenção psicológica. Universidade do Minho. Tese de Mestrado. Braga. 2008.

LANCASTER, P.; RUDOLPH, C. P. S.; PATTERN, T. Difficulties in career decsiona making: A study of the reliability and validity of the careeer decsion difficulties questionnaire. Journal od Career Assesssment, v. 4, p. 393-413, 1999. 
LOUREIRO, N.; TAVEIRA, M. C. Dificuldades de Tomada de Decisão de Carreira em Alunos do Ensino Superior: Estudo Exploratório das Características o CDDQ. Comunicação apresentada à VI Conferência de Desenvolvimento Vocacional, Braga, 23 de Abril, 2010.

MARKS, N. G. Issues in the school to work transition. Journal of Sociology, v. 41, n. 4, p. 363-385, 2005.

MARSH, H. W., BALLA, J. R. \& MCDONALD, R. P. (1988). Goodness-of-fit indexes in confirmatory factor analisys: the effect of sample size. Psychological Bulletin,v. 103, p. 391410,1988 .

MAU, W. C. Assessing career decison-making difficulties: a cross-cultural study. Journal of Career Assessment, n. 9, p. 353-364, 2001.

MAU, W. C.; JEPSEN, D. A. Effects of computer-assisted instruction in using formal decision-making strategies to choose a college major. Journal of Counseling Psychology, n. 39, p. 187-197, 1992.

MELO-SILVA, L. L.; DUARTE, V. C.; REIS, B. A. V. Orientação Profissional: um aprendizado de mão dupla. Psico, São Paulo, v. 36, n. 3, p. 315-323, 2005.

MELO-SILVA, L. L; JACQUEMIN, A. Intervenção em orientação profissional: avaliando resultados e processos. São Paulo: Vetor, 2001.

MELO-SILVA, L.; LASSANCE, M. C. P.; SOARES, D. H. P. A orientação profissional no

NEIVA, K. M. C. Fim dos estudos universitários:efeitos das dificuldades do mercado de trabalho e na representaçaõ do futuro profissional e nos estabelecimentos de projetos posuniversitários dos estudantes. Psicologia USP, São Paulo, v. 7, p. 203-224, 1996.

NILES, S. G.; BOWLSBEY, J. H. Career development interventions in the 21st century. 2nd ed. Ohio: Prentice Hall, 2005.

NUNES, E.; CARVALHO, M. M. Ensino Universitário, Corporação e Profissão: paradoxos e dilemas brasilieros. Instituto Databrasil. Rio de Janeiro, p. 31. 2006.

NUNNALly, J. C. Psychometric Theory. Nova Iorque: McGraw- Hill, 1978. 
OLIVEIRA, M. C.; GUIMARÃES, V. F.; COLETA, M. F. D. Modelo desenvolvimentista de avaliação e orientação de carreira proposto por Donald Super. Revista Brasileira de Orientação Profissional, São Paulo, v. 7, n. 2, p. 11-18, 2006.

PASQUALI, A.; ALVES, A. R.; PEREIRA, A. A. M. Escala de Locus de controle: Manual técnico e de avaliação. São Paulo: Casa do Psicólogo, 1997.

PASQUAl, L. Técnicas de Exame Psicológico- TEP: manual. São Paulo: Casa do Psicólogo, 2001.

PASQUALI, L. Análise Fatorial para Pesquisadores. Brasília: LabPAM, 2005.

PASQUALI, L. Psicometria; teoria dos testes na psicologia e na educação. Petrópolis: Vozes, 2009.

PASQUALI, L. Instrumentação psicológica: fundamentos e prática. Porto Alegre: Artemed, 2010.

PASQUALI, L.; AZEVEDO, M. M.; GHESTI, I. Inventário Fatorial da Personalidade: Manual técnico de avaliação. São Paulo: Casa do Psicólogo, 1997.

PESTANA, M. H.; GAGEIRO, J. G. Análise de dados para as ciências sociais: a complementariedade do SPSS. 3. ed. Lisboa: Silabo, 2003.

PETERSO, G.; J., S.; REARDON, R. Career developmet and services. A congnitive approach. California: Brooks/ Cole Publishing Company, 1991.

PHILIPS, S. Toward an expanded definition os adaptative decision-making. The Careeer Development Quartely, v. 45, p. 275-287, 1997.

PRIMI, R.; MUNHOZ, A. M. H., BIGHETTI, C. A.; DI NUCCI, E. P; PELLEGRIN, M. C. K.; MOGGI, M. A. Desenvolvimento de inventário de levantamento das dificuldades de decisão profissional. Psicologia; Reflexão e Crítica, 13 (3), 451-463, 2000.

RIBEIRO, M. A.; UVALDO, M. C. C. Frank Parsons: trajetória do pioneiro da orientação vocacional, profissional e de carreira. Revista Brasileira de Orientação Profissional, São Paulo, v. 8, n. 1, p. 19-31, 2007.

SAS INSTITUTE. SAS/STAT user s guide, version 9. Cary, NC: SAS Institute Inc., 2009. 
SAVICKAS, M. L. The theory and pratice os career construction. Career development and couselling: Putting and reserach to work, New Jersey, p. 42-70, 2005.

SCHLOSSBERG, N. K.; WATERS, E. B.; GOODMAN, J. Counseling adults in trasition. New York: Springer Publishing Company, 1995.

SEVERINO, J. A. Expansão do ensino superior: contextos, desafios e possibilidades. Avaliação do Ensino Superior, Campinas, v. 14, n. 2, p. 253-266, 2009.

SILVA, J. T.; RAMOS, L. A. Fiabilidade e validade da versão Portugueesa do questionário das Dificuldades de Tomadade de Decisão de Careira: Estudo Piloto. Psicologia e Educação, v. 7, 2008.

SILVA, J. T. Avaliação da indecisão vocacional. In: LEITÃO, L. M. (Org.). Avaliação psicológica em orientação escolar e profissional. Coimbra: Quarteto, 2004. p. 347- 386.

SIMÕES, D. M. N. Dificuldades de Tomada de Decisão de Carreira no contexto da Intervenção Vocacional. Universidade do Minho. Minho, p. 45. 2010

TABACHNICK, B. G.; S., F. L. Using a multivariate statistics. $2^{\circ}$ Edição. ed. New York: Harper Collings Publishers, 1989.

TAVEIRA, M. C. Exploração e desenvolvimento vocacional de jovens: estudo sobre as relações entre a exploração, a identidade e a indecisão vocacional. Braga: UM/IEP. Dissertação apresentada para obtenção do grau de Doutor,2000.

TAYLOR, G. J.; BAGBY, R. M.; PARKER, J. D. The twenty item Toronto Scale. Reability and factorial validity in different languages and cultures. Journal os Psychosomatic Reserach, v. 55, p. 277-283.

TEIXEIRA, M. A. P. A experiência de transição entre a universidade e o mercado de trabalho na adultez jovem. Tese de Doutorado. Universidade Federal do Rio grande do Sul. Porto Alegre. 2002.

SUPER, D. E.; THOMPSON, A. S.; LINDEMAN, R. H.; JORDAAN, J. P.; MYERS, R. A. The Career Development Inventory. Palo Alto, CA: Consulting Psychologists Press, 1981

TIEDEMAN, D. V.; O'HARA, R. Career development; Choice and adjustment. New York: College Examination Board, 1963.

USSENE, C.; TAVEIRA, M. C. Estudo do Career Decision-Making Difficulties Questionnaire com Estudantes do Ensino Secundário Moçambicano. Comunicação apresentada à VI Conferência de Desenvolvimento Vocacional, Braga, 23 de Abril, (2010). 
UVALDO, M. C. C.; SILVA, F. F. Escola e escolha profissional - um olhar sobre a construção de projetos profissionais. In: LEVENFUS, R. S.; SOARES, D. H. P. (Org.). Orientação vocacional ocupacional. 2. ed. Porto Alegre: Artmed. 2009. p. 31-38.

VIOLA, L. Eficácia da versão revista do programa Futuro Bué! Em Estudantes do Ensino Básico. Tese de Mestrado. Braga: Universidade do Minho,2008

WENDLANT, N. M.; ROCHLEN, A. B. Adressing the College-to-work-transition. Journal of Career Development, Missouri, v. 35, n. 2, p. 151-165, Dezembro 2008.

WOODS, D. The impact of VET on transition to work for young people in Australia. Education Training, Adelaide, v. 50, n. 6, p. 465-473, 2008.

ZAKAY, D.; BARAK, A. Meaning and career decision making. Journal of Vocational, V.24,p.1-14, 1984. 
ANEXOS E APÊNDICES 

ANEXO A - Questionário Sócioeconômico - ABEP
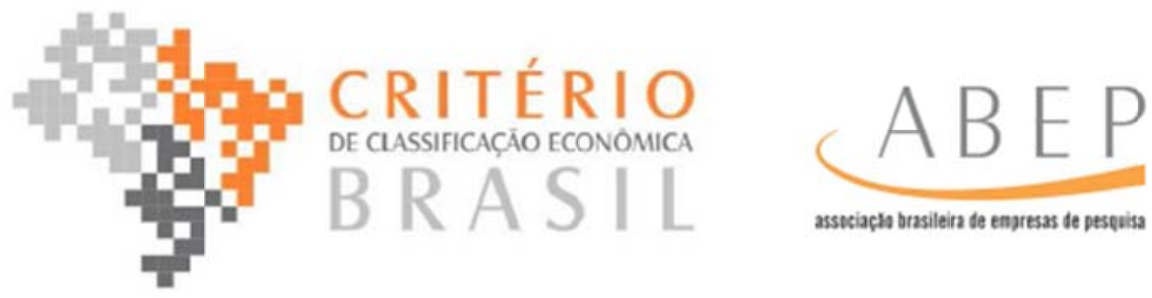

- Critério de Classificação Econômica Brasil, enfatiza sua função de estimar o poder de compra das pessoas e familias urbanas, abandonando a pretensão de classificar a população em termos de "classes sociais". A divisão de mercado definida abaixo é de classes econômicas.

\section{SISTEMA DE PONTOS}

Posse de itens

\begin{tabular}{|c|c|c|c|c|c|}
\hline & \multicolumn{5}{|c|}{ Quantidade de Itens } \\
\hline & 0 & 1 & 2 & 3 & 4 ou + \\
\hline Televisão em cores & 0 & 1 & 2 & 3 & 4 \\
\hline Rádio & 0 & 1 & 2 & 3 & 4 \\
\hline Banheiro & 0 & 4 & 5 & 6 & 7 \\
\hline Automóvel & 0 & 4 & 7 & 9 & 9 \\
\hline Empregada mensalista & 0 & 3 & 4 & 4 & 4 \\
\hline Máquina de lavar & 0 & 2 & 2 & 2 & 2 \\
\hline Videocassete e/ou DVD & 0 & 2 & 2 & 2 & 2 \\
\hline Geladeira & 0 & 4 & 4 & 4 & 4 \\
\hline Freezer (aparelho independente ou parte da geladeira duplex) & 0 & 2 & 2 & 2 & 2 \\
\hline
\end{tabular}

Grau de Instrução do chefe de familia Analfabeto / Primário incompleto Analfabeto/Até $3^{*}$. Série Fundamental Primário completo / Ginasial incompleto Ginasial completo / Colegial incompleto Colegial completo / Superior incompleto Superior completo

Até $4^{*}$. Série Fundamental

Fundamental completo

Médio completo

Superior completo

\section{CORTES DO CRITÉRIO BRASIL}

\begin{tabular}{|c|c|}
\hline Casse & Pontos \\
\hline A1 & $42-46$ \\
\hline A2 & $35-41$ \\
\hline B1 & $29-34$ \\
\hline B2 & $23-28$ \\
\hline C1 & $18-22$ \\
\hline C2 & $14-17$ \\
\hline D & $8-13$ \\
\hline E & $0-7$ \\
\hline
\end{tabular}




\title{
ANEXO B - Termo de Consentimento Livre e Esclarecido
}

\section{TERMO DE CONSENTIMENTO PARA PARTICIPAÇÃO EM PESQUISA}

Concordo em participar, como voluntário/a, da pesquisa "O processo de transição de jovens universitários para o mercado de trabalho: fatores facilitadores e inibidores”, que será desenvolvida por Juliana Maria Cava, em nível de mestrado, sob orientação da Prof. ${ }^{a}$ Dr. ${ }^{a}$ Lucy Leal Melo-Silva, professora e pesquisadora do Departamento de Psicologia e Educação da Faculdade de Filosofia, Ciências e Letras de Ribeirão Preto (FFCLRP - USP). Este estudo será realizado com estudantes universitários. Trata-se de uma pesquisa totalmente gratuita, com adesão voluntária dos participantes, que não oferece riscos à saúde e nenhum problema ou ônus financeiro.

Estou ciente de que minha participação tem como objetivo contribuir para o entendimento dos fatores facilitadores e inibidores presentes na transição da universidade para o mercado de trabalho.

Declaro ainda que:

(1)recebi informações sobre a pesquisa e que o estudo terá uma duração média de 50 minutos;

(2) estou aceitando voluntariamente a participação nesse estudo, não tendo sofrido nenhuma forma de pressão para isso;

(3) se desejar, posso deixar de participar do estudo a qualquer momento;

(4) esse estudo possui uma finalidade de pesquisa e que os dados obtidos serão utilizados em divulgações e publicações científicas, sem que os participantes sejam identificados; e,

(5) se desejar, terei conhecimento dos resultados da pesquisa.

LOCAL E DATA

\section{Nome por extenso}

RG:

\author{
Assinatura \\ Juliana Maria Cava - Pesquisadora \\ Psicóloga \\ CRP 04/25897 \\ (35) 3712-3158 / e-mail: jumcava@yahoo.com.br
}




\section{ANEXO C - Autorização do Comitê de Ética em Pesquisa}

UNIVERSIDADE DE SÃO PAULO

FACULDADE DE FILOSOFIA, CIÊNCIAS E LETRAS DE RIBEIRÃO PRETO

COMITÊ DE ÉTICA EM PESQUISA - CEP

Of.CEtP/FFCLRP-USP.005/2010-15/03/2010

Senhor(a) Pesquisador(a):

Comunicamos a V. Sa. que o trabalho intitulado "O processo de transição de jovens universitários para o mercado de trabalho:fatores facilitadores e inibidores", foi analisado pelo Comitê de Ética em Pesquisa da FFCLRP-USP, e, enquadrado na categoria: APROVADO, de acordo com o Processo CEP-FFCLRP $n^{\circ}$ 466/2009-2009.1.1945.59.9

Atenciosamente,

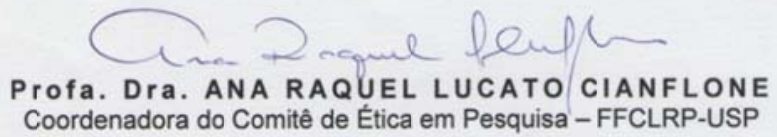

llustríssimo(a) Senhor(a):

Juliana Maria Cava

Aluna do Programa de PG em Psicologia

c.c.:

Profa. Dra. Lucy Leal Melo Silva

Docente do Departamento de Psicologia e Educaçăo

Desta FFCLRP-USP

CEP-FFCLRP-USP - coetp@ ffelrp.usp.br Fone: (016) 3602-3653 - Fax: (016) 3633-5015 Avenida Bandeirantes, 3900 - Bloco A - 14040-901 - Ribeirão Preto - SP - Brasil 


\section{Autorização do Comitê de Ética em Pesquisa e carta com solicitações de modificações.}

Profa. Dra. Ana Raquel Lucato Cianflone

DD. Coordenadora do Comitê de Ética em Pesquisas

com seres humanos

FFCLRP - USP

Assunto: acompanhamento do desenvolvimento do processo

Prezada Senhora:

Tem esta o objetivo de informar sobre modificações desenvolvimento do projeto de Mestrado intitulado: “ $O$ processo de transição de jovens universitários para o mercado de trabalho: fatores facilitadores e inibidores”, que foi desenvolvido sob a minha orientação, nível Mestrado de autoria de Juliana Maria Cava junto ao Programa de PósGraduação em Psicologia, do Departamento de Psicologia e Educação desta Faculdade. O referido projeto foi analisado pelo Comitê de Ética em Pesquisa (CEP) da FFCLRP/USP e enquadrado na categoria: aprovado, de acordo com o processo CEPFFCLRP n ${ }^{\circ}$ 466/2009 - 2009.1.1945.59.9.

Cumpre esclarecer que o projeto, durante seu percurso metodológico, sofreu determinadas modificações em sua versão inicial que não alteram os cuidados éticos em pesquisa com seres humanos. Entretanto, julgou-se pertinente informar ao CEP sobre as alterações realizadas.

A primeira modificação refere-se a modificação do objetivos propostos, ficando estes restritos a validação do instrumento utilizado. Nas alterações o objetivo foi definido como se segue.

(a) O presente estudo tem como objetivo geral, analisar as qualidades psicométricas em termos de confiabilidade e validade dos resultados, e analisar os resultados em termos de validade da versão brasileira do Questionário de Dificuldades de Tomada de Decisão de Carreira (CDDQ34q, GATI; SAKA, 2001), com alunos finalistas do Ensino Superior, de diferentes cursos de três universidades brasileiras.

Também foi realizada a mudança no título, que passou a ser: "Decisão de carreira na transição da universidade para o mercado de trabalho: validação de instrumento de medida”, considerado mais adequado à pesquisa realizada.

Acredita-se que os ajustes metodológicos se justificam em função do processo de amadurecimento na realização da pesquisa, uma vez que foram pautados em adequações pertinentes ao alcance do objetivo. Outrossim, cumpre informar que foram devidamente resguardados os cuidados éticos na obtenção e tratamento dos dados pertinentes aos projetos de pesquisa que envolvem seres humanos.

Estamos à disposição para eventuais esclarecimentos. Subscrevemos com elevados protestos de estima e consideração.

Atenciosamente,

Juliana Maria Cava

(Orientanda)
Profa. Dra. Lucy Leal Melo-Silva

(Orientadora) 


\section{ANEXO D - Autorização para utilização do CDDQ e sua condições.}

Itamar Gati, Ph, D.

Sehoul of Education, Hebrew University, Jerusalem, 1SRAFI.

e-mail itamar.gati@huji.at il

Fax. $(+972)-2-58820144$

If yıu agree to the following conditions, please sign the attached statement, indicate the mumber of coppies you desire to reprextuce for your research, and mail 2 copies to me at the thoove addresx. When I roceive the signetl cupies I will send you a conpy of the CDDQ along with your copy or the signed permission slip that will allow you to reproducs the instrumett. Please limit requests to no morc than 1000 at a time If you noed more, plense kt me know. Permission expiress ber yeur yfor it is granted

Nate: The instrament must be rcproduced in its entirety. Petmission 1e reproduce separsite ilems is not grabted.

1. I geree to reprodexc the insilurnent in its cmirety with no changes in content of format.

2. 1 arree to include the copyriglt slatcmcm shown on the imatniment. Please add that it has been reproduced with the pernissiren of the suthors.

3. I will share the results of my research with Guti and Osiposw and provicle specific data for secundary analysis with the understanding that uppropriate credit wil] he eited.

4. This pcrmission to reproduce is limited to this occasion; peunnission cxpires in nde ytad from the date of the permission letter; permissirn is limited to 1000 arpiess firture reproducticn reques1s must be specificselly and separately ropucsted.

5. Fojeign franslations mest be back translated into English and approwad by Osipow or Guti

I agree to the ahuve conditions.

Name: Lacy I ead Meto-Stra \& Julinne Maria Cava

Date: 05/10/09

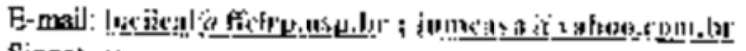

Signature.

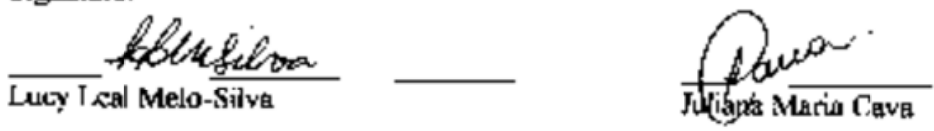

Tax: $+551636024835 \quad$ Tel: +551636023789

\section{Address: Avenida Bandeirantes, 3\%9 \\ 14040-901 - Ribcirāo Preto, SP, BRASLL}

Itamar Gat

P'crmission is not. granted without the signature of Itamar Gati in this space.

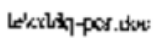


APÊNDICE A - Descrição das escalas do CDDQ por sexo e resultados das comparações com os 3 fatores .

\begin{tabular}{llccccccc}
\hline \multicolumn{1}{c}{ Escala } & Sexo & $\mathrm{n}$ & Média & DP & Mínimo & Mediana & Máximo & p-valor \\
\hline Falta de preparação & Masculino & 225 & 3,86 & 1,19 & 1 & 3,9 & 7,4 & 0,671 \\
& Feminino & 275 & 3,79 & 1,1 & 1 & 3,8 & 6,8 & \\
Falta de informação & & & & & & & & \\
& Masculino & 225 & 2,86 & 1,61 & 1 & 2,58 & 7,5 & 0,412 \\
& Feminino & 275 & 2,76 & 1,64 & 1 & 2,42 & 8 & \\
Informações & Masculino & 225 & 2,62 & 1,54 & 1 & 2,2 & 7,2 & $0,030^{*}$ \\
Inconsistentes & Feminino & 275 & 2,25 & 1,21 & 1 & 1,8 & 7,3 & \\
\hline
\end{tabular}


APÊNDICE B - Descrição das escalas do CDDQ por estado civil e resultados das comparações com os $\mathbf{3}$ fatores.

\begin{tabular}{llccccccc}
\hline \multirow{2}{*}{ Escala } & $\begin{array}{c}\text { Estado } \\
\text { civil }\end{array}$ & $\mathrm{n}$ & Média & DP & Mínimo & Mediana & Máximo & p-valor \\
\hline Falta de preparação & Solteiro & 464 & 3,87 & 1,12 & 1,2 & 3,9 & 7,4 & $0,017^{*}$ \\
& Casado & 32 & 3,35 & 1,27 & 1 & 3,35 & 5,8 & \\
& Divorciado & 4 & 2,63 & 1,31 & 1 & 2,65 & 4,2 & \\
Falta de informação & Solteiro & 464 & 2,85 & 1,64 & 1 & 2,5 & 8 & $0,006^{*}$ \\
& Casado & 32 & 2,23 & 1,35 & 1 & 1,88 & 6 & \\
& Divorciado & 4 & 1,31 & 0,63 & 1 & 1 & 2,25 & \\
Informações & & & & & & & & \\
Inconsistentes & Solteiro & 464 & 2,44 & 1,39 & 1 & 2,1 & 7,3 & 0,161 \\
& Casado & 32 & 2,15 & 1,25 & 1 & 1,65 & 5,3 & \\
& Divorciado & 4 & 1,48 & 0,46 & 1 & 1,45 & 2 & \\
\hline
\end{tabular}


APÊNDICE C - Descrição das escalas do CDDQ por faculdade e resultados das comparações com os 3 fatores.

\begin{tabular}{llccccccc}
\hline \multicolumn{1}{c}{ Escala } & Faculdade & $\mathrm{n}$ & Média & DP & Mínimo & Mediana & Máximo & p-valor \\
\hline Falta de preparação & Pública & 288 & 3,89 & 1,12 & 1 & 3,95 & 7,4 & $0,042^{*}$ \\
& Privada & 212 & 3,73 & 1,16 & 1 & 3,6 & 7,4 & \\
Falta de informação & & & & & & & & \\
& Pública & 288 & 2,96 & 1,75 & 1 & 2,58 & 8 & 0,072 \\
& Privada & 212 & 2,59 & 1,41 & 1 & 2,29 & 7 & \\
Informações & Pública & 288 & 2,55 & 1,49 & 1 & 2,2 & 7,3 & 0,062 \\
Inconsistentes & Privada & 212 & 2,23 & 1,18 & 1 & 1,85 & 6,6 & \\
\hline
\end{tabular}


APÊNDICE D - Descrição das escalas do CDDQ por inserção e resultados das comparações com os $\mathbf{3}$ fatores.

\begin{tabular}{|c|c|c|c|c|c|c|c|c|}
\hline Escala & Inserção & $\mathrm{n}$ & Média & DP & Mínimo & Mediana & Máximo & p-valor \\
\hline \multirow[t]{2}{*}{ Falta de preparação } & Sim & 471 & 3,81 & 1,13 & 1 & 3,8 & 7,4 & 0,318 \\
\hline & Não & 29 & 3,98 & 1,33 & 1 & 4,3 & 7,4 & \\
\hline \multirow[t]{2}{*}{ Falta de informação } & Sim & 471 & 2,79 & 1,63 & 1 & 2,42 & 8 & 0,470 \\
\hline & Não & 29 & 2,97 & 1,61 & 1 & 2,92 & 6,67 & \\
\hline Informações & Sim & 471 & 2,37 & 1,35 & 1 & 2 & 7,3 & $0,004^{*}$ \\
\hline Inconsistentes & Não & 29 & 3,18 & 1,57 & 1 & 3 & 7 & \\
\hline
\end{tabular}


APÊNDICE E - Descrição das escalas do CDDQ por nível de confiança e resultados das comparações com os 3 fatores.

\begin{tabular}{|c|c|c|c|c|c|c|c|c|}
\hline Escala & $\mathrm{NC}$ & $\mathrm{n}$ & Média & DP & Mínimo & Mediana & Máximo & p-valor \\
\hline \multirow[t]{9}{*}{ Falta de preparação } & 1 & 4 & 4,33 & 1,41 & 2,4 & 4,65 & 5,6 & \multirow[t]{9}{*}{$<0,001$} \\
\hline & 2 & 4 & 4,5 & 0,42 & 4 & 4,5 & 5 & \\
\hline & 3 & 6 & 4,48 & 1,52 & 2,2 & 4,5 & 6,2 & \\
\hline & 4 & 9 & 4,78 & 1,36 & 2,7 & 4,8 & 7,4 & \\
\hline & 5 & 78 & 4,26 & 1,16 & 1,4 & 4,25 & 7,4 & \\
\hline & 6 & 39 & 4,12 & 1,1 & 2,1 & 4,2 & 6,3 & \\
\hline & 7 & 108 & 3,71 & 1,08 & 1,2 & 3,6 & 7,2 & \\
\hline & 8 & 113 & 3,92 & 1,07 & 1 & 3,9 & 7 & \\
\hline & 9 & 139 & 3,38 & 1,04 & 1 & 3,3 & 6,1 & \\
\hline \multirow[t]{9}{*}{ Falta de informação } & 1 & 4 & 3,33 & 1,65 & 1,5 & 3,17 & 5,5 & \multirow[t]{9}{*}{$<0,001$} \\
\hline & 2 & 4 & 4,65 & 2,03 & 2,83 & 4,25 & 7,25 & \\
\hline & 3 & 6 & 4,89 & 2,03 & 1 & 6 & 6,08 & \\
\hline & 4 & 9 & 4,02 & 2 & 1,42 & 3,58 & 6,92 & \\
\hline & 5 & 78 & 3,65 & 1,71 & 1 & 3,7 & 7,5 & \\
\hline & 6 & 39 & 3,51 & 1,54 & 1 & 3,42 & 7,58 & \\
\hline & 7 & 108 & 3,07 & 1,77 & 1 & 2,54 & 8 & \\
\hline & 8 & 113 & 2,5 & 1,28 & 1 & 2,33 & 5,92 & \\
\hline & 9 & 139 & 1,92 & 1,07 & 1 & 1,5 & 6,5 & \\
\hline Informações & 1 & 4 & 4,13 & 1,29 & 2,6 & 4,35 & 5,2 & \multirow[t]{9}{*}{$<0,001$} \\
\hline \multirow[t]{8}{*}{ Inconsistentes } & 2 & 4 & 5,03 & 1,51 & 3,7 & 4,6 & 7,2 & \\
\hline & 3 & 6 & 4,93 & 2,11 & 1 & 5,15 & 6,8 & \\
\hline & 4 & 9 & 4,14 & 1,91 & 1,2 & 4 & 6,8 & \\
\hline & 5 & 78 & 3,27 & 1,69 & 1 & 3 & 7,3 & \\
\hline & 6 & 39 & 3,01 & 1,32 & 1 & 3,2 & 5,4 & \\
\hline & 7 & 108 & 2,38 & 1,2 & 1 & 2,05 & 6,2 & \\
\hline & 8 & 113 & 1,99 & 0,92 & 1 & 1,8 & 5,9 & \\
\hline & 9 & 139 & 1,79 & 0,85 & 1 & 1,6 & 4,7 & \\
\hline
\end{tabular}


APÊNDICE F - Descrição das escalas do CDDQ por classe social e resultados das comparações com os 3 fatores.

\begin{tabular}{|c|c|c|c|c|c|c|c|c|}
\hline Escala & $\begin{array}{l}\text { Classe } \\
\text { social }\end{array}$ & $\mathrm{n}$ & Média & DP & Mínimo & Mediana & Máximo & $\mathrm{p}$-valor \\
\hline \multirow[t]{7}{*}{ Falta de preparação } & A1 & 38 & 3,19 & 0,83 & 1,9 & 3,1 & 4,9 & \multirow[t]{7}{*}{0,200} \\
\hline & $\mathrm{A} 2$ & 137 & 3,18 & 0,98 & 1 & 3,1 & 6,7 & \\
\hline & B1 & 135 & 2,97 & 0,91 & 1 & 3,1 & 6,1 & \\
\hline & B2 & 117 & 3,14 & 1,06 & 1 & 3,1 & 6,7 & \\
\hline & $\mathrm{C} 1$ & 47 & 2,76 & 0,95 & 1 & 2,8 & 4,9 & \\
\hline & $\mathrm{C} 2$ & 20 & 3,19 & 1,38 & 1,6 & 2,8 & 5,8 & \\
\hline & $\mathrm{D}$ & 6 & 3,4 & 1,12 & 1,6 & 3,55 & 4,6 & \\
\hline \multirow[t]{7}{*}{ Falta de informação } & A1 & 38 & 1,84 & 1,07 & 1 & 1,38 & 4,25 & \multirow[t]{7}{*}{0,481} \\
\hline & $\mathrm{A} 2$ & 137 & 2,31 & 1,47 & 1 & 1,75 & 6,5 & \\
\hline & B1 & 135 & 2,06 & 1,3 & 1 & 1,5 & 7 & \\
\hline & B2 & 117 & 2,32 & 1,46 & 1 & 1,75 & 6,5 & \\
\hline & $\mathrm{C} 1$ & 47 & 2,03 & 1,12 & 1 & 1,75 & 5,25 & \\
\hline & $\mathrm{C} 2$ & 20 & 1,98 & 1,09 & 1 & 1,5 & 4,5 & \\
\hline & $\mathrm{D}$ & 6 & 2,92 & 1,79 & 1 & 2,88 & 5,25 & \\
\hline Informações & A 1 & 38 & 1,62 & 0,8 & 1 & 1,3 & 4,3 & \multirow[t]{7}{*}{0,397} \\
\hline \multirow[t]{6}{*}{ Inconsistentes } & $\mathrm{A} 2$ & 137 & 2,08 & 1,18 & 1 & 1,6 & 5,8 & \\
\hline & B1 & 135 & 1,88 & 1,11 & 1 & 1,6 & 6,7 & \\
\hline & B2 & 117 & 2,01 & 1,22 & 1 & 1,6 & 5,8 & \\
\hline & $\mathrm{C} 1$ & 47 & 1,73 & 0,91 & 1 & 1,3 & 4,6 & \\
\hline & $\mathrm{C} 2$ & 20 & 1,84 & 0,9 & 1 & 1,45 & 3,7 & \\
\hline & $\mathrm{D}$ & 6 & 2,65 & 1,88 & 1 & 2,2 & 5,8 & \\
\hline
\end{tabular}


APÊNDICE G - Descrição das escalas do CDDQ por área de curso e resultados das comparações com os 3 fatores.

\begin{tabular}{llccccccc}
\hline \multicolumn{1}{c}{ Escala } & \multicolumn{1}{c}{ Curso } & $\mathrm{n}$ & Média & DP & Mínimo & Mediana & Máximo & p-valor \\
\hline Falta de preparação & Biológicas & 111 & 3,95 & 1,16 & 1 & 4 & 6,9 & 0,109 \\
& Exatas & 128 & 3,87 & 1,09 & 1,3 & 3,95 & 7,4 & \\
& Humanas & 261 & 3,75 & 1,15 & 1 & 3,7 & 7,4 & \\
Falta de informação & Biológicas & 111 & 2,99 & 1,92 & 1 & 2,42 & 8 & 0,360 \\
& Exatas & 128 & 2,86 & 1,48 & 1 & 2,67 & 6,92 & \\
& Humanas & 261 & 2,69 & 1,55 & 1 & 2,33 & 7,58 & \\
Informações & Biológicas & 111 & 2,41 & 1,49 & 1 & 2 & 7,3 & 0,172 \\
Inconsistentes & Exatas & 128 & 2,55 & 1,35 & 1 & 2,3 & 7 & \\
& Humanas & 261 & 2,35 & 1,34 & 1 & 1,9 & 6,8 & \\
\hline
\end{tabular}

